\title{
Characterization of Interactions between Surface Water and Near-Stream Groundwater along Fish Creek, Teton County, Wyoming, by Using Heat as a Tracer
}

Scientific Investigations Report 2009-5160
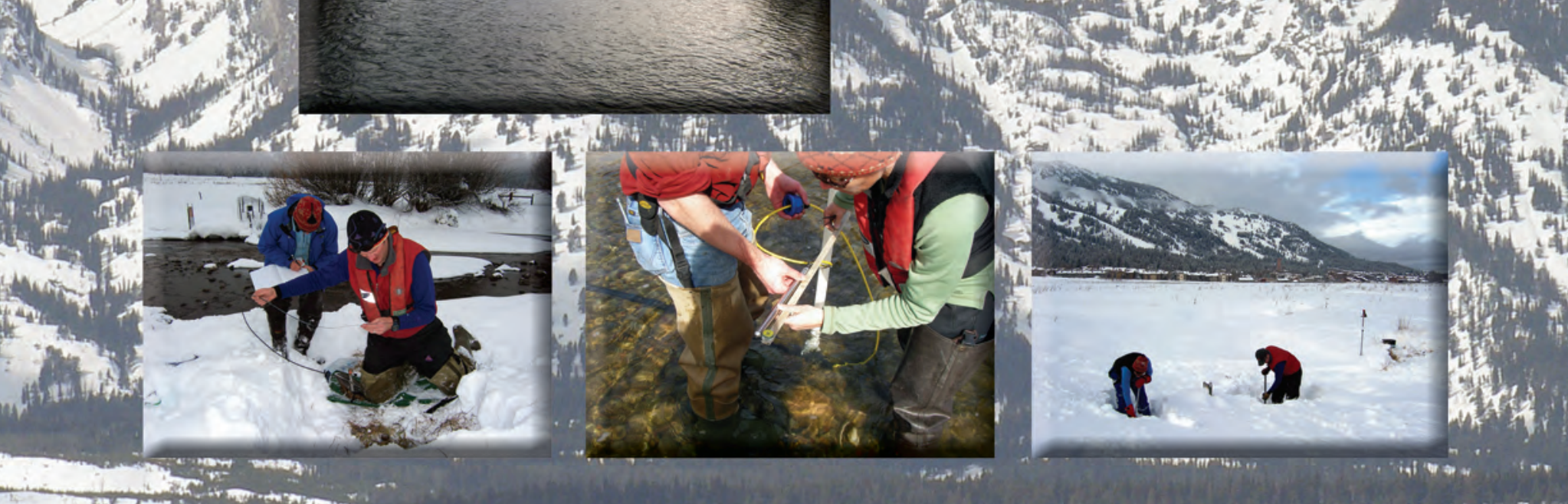

काष 400 

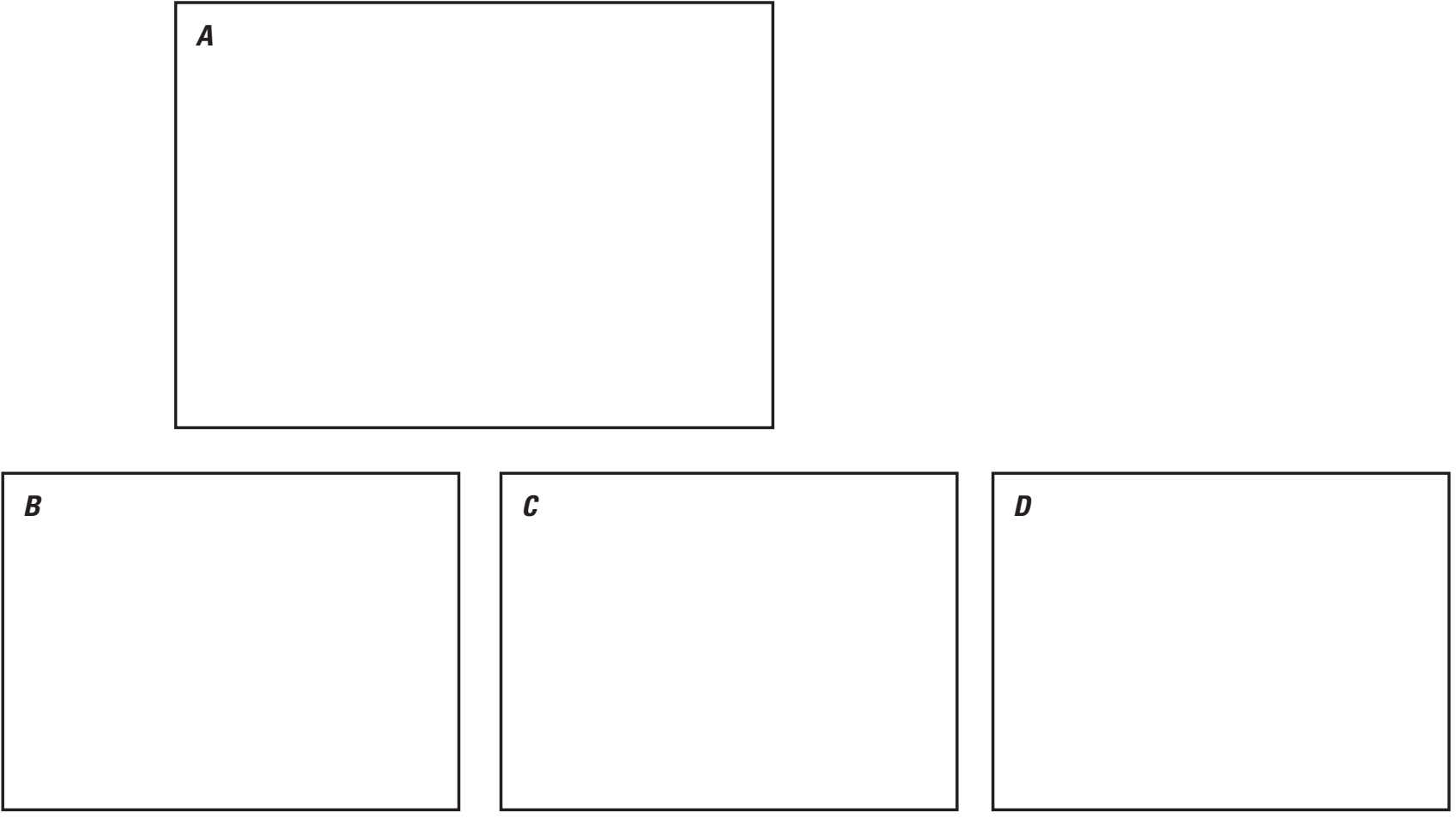

Front cover. Background; The Teton Range as seen from Teton Point turnout on U.S. Highway 26/89, Wyoming, March 9, 2007. Photograph by Cheryl Eddy-Miller, U.S. Geological Survey.

A; Fish Creek at Wilson, Wyoming, December 20, 2005. Photograph by Rodney Caldwell, U.S. Geological Survey.

$B$; Measuring water levels at Resor's Bridge cross section, Wyoming, December 20, 2005. Photograph by Rodney Caldwell, U.S. Geological Survey.

C; Instrumentation in the W3 piezometer, Fish Creek at Wilson, Wyoming, March 3, 2005. Photograph by Brian Remlinger, Teton Conservation District.

D; Teton Village cross section, Wyoming, December 20, 2005. Photograph by Rodney Caldwell, U.S. Geological Survey. 


\section{Characterization of Interactions between Surface Water and Near-Stream Groundwater along Fish Creek, Teton County, Wyoming, by Using Heat as a Tracer}

By Cheryl A. Eddy-Miller, Jerrod D. Wheeler, and Hedeff I. Essaid

Prepared in cooperation with the Teton Conservation District

Scientific Investigations Report 2009-5160 


\title{
U.S. Department of the Interior \\ KEN SALAZAR, Secretary
}

\author{
U.S. Geological Survey \\ Suzette M. Kimball, Acting Director
}

U.S. Geological Survey, Reston, Virginia: 2009

For more information on the USGS - the Federal source for science about the Earth, its natural and living resources, natural hazards, and the environment, visit http://wWw.usgs.gov or call 1-888-ASK-USGS

For an overview of USGS information products, including maps, imagery, and publications, visit $h$ ttp://www.usgs.gov/pubprod

To order this and other USGS information products, visit http://store.usgs.gov

Any use of trade, product, or firm names is for descriptive purposes only and does not imply endorsement by the U.S. Government.

Although this report is in the public domain, permission must be secured from the individual copyright owners to reproduce any copyrighted materials contained within this report.

Suggested citation:

Eddy-Miller, C.A., Wheeler, J.D., and Essaid, H.I., 2009, Characterization of interactions between surface water and near-stream groundwater along Fish Creek, Teton County, Wyoming, by using heat as a tracer: U.S. Geological Survey Scientific Investigations Report 2009-5160, 53 p. 


\section{Contents}

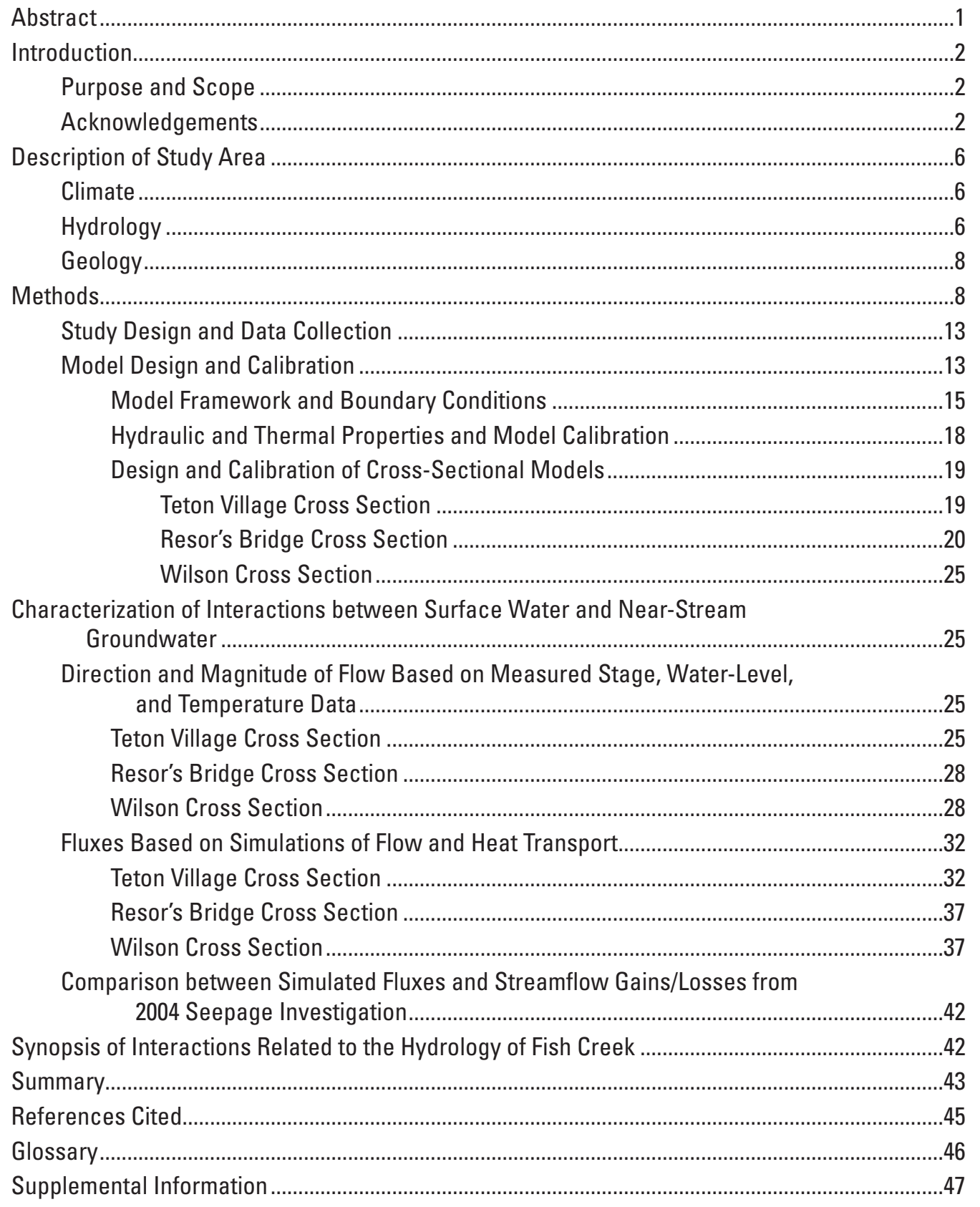

\section{Figures}

\section{1-3. Maps showing:}

1. Location of Fish Creek as part of the Jackson Hole valley, Wyoming ........................3

2. Locations of three piezometer cross sections and miscellaneous thermal measurement site on and near Fish Creek, Wyoming .. 
3. Streamflow at seepage investigation sites and identification of reaches with and without gains from groundwater, Fish Creek, Wyoming

4-6. Graphs showing:

4. Maximum and minimum temperatures, and precipitation recorded at meteorological station 486428 at Moose, Wyo., June 1, 2005, to October 11, 2006

5. Mean daily streamflow for water years 2005 and 2006, and median streamflow for 1994-2006, Fish Creek at Wilson (station 13016450)

6. Cumulative streamflow for water years 2005 and 2006, for water year 1995 (lowest annual streamflow), and for 1994-2006 (from mean daily streamflow), Fish Creek at Wilson (station 13016450).

7. Map showing generalized geology and diagram showing geologic section in the vicinity of Fish Creek

8-13. Schematics showing:

8. Streambed flow and heat transport in a gaining and a losing reach of a stream

9. Channel geometry, piezometer network, and thermistor and/or pressure transducer locations at Teton Village cross section

10. Channel geometry, piezometer network, and thermistor and/or pressure transducer locations at Resor's Bridge cross section

11. Channel geometry, piezometer network, and thermistor and/or pressure transducer locations at Wilson cross section

12. Generalized two-dimensional VS2DH model of water and heat transport through the near-stream aquifer along Fish Creek

13. Boundary conditions and observation points for the VS2DH model for the Teton Village cross section

14. Graphs showing simulated and measured temperatures for the Teton Village cross section

15. Schematic showing boundary conditions and observation points for the VS2DH model for the Resor's Bridge cross section.

16. Graphs showing simulated and measured temperatures for the Resor's Bridge cross section

17. Schematic showing boundary conditions and observation points for the VS2DH model for the Wilson cross section

18. Graphs showing simulated and measured temperatures for the Wilson cross section

19-21. Graphs showing:

19. Data collected at the Teton Village cross section .29

20. Data collected at the Resor's Bridge cross section .30

21. Data collected at the Wilson cross section.

22-25. Graphs and schematics showing:

22. Selected flux information for the Teton Village cross section.

23. Average air temperature at Moose, Wyo., stage of Snake River and Fish Creek, and groundwater levels at selected piezometers in the study area

24. Selected flux information for the Resor's Bridge cross section ...............................38

25. Selected flux information for the Wilson cross section. 
26-31. Graphs showing:

26. Data from Teton Village cross section, April to October 2006: mean daily temperatures for Fish Creek, piezometers, and soil; stage in Fish Creek; and water levels in center piezometer.

27. Stage in Fish Creek and mean daily and hand-measured water levels in piezometers, Teton Village cross section

28. Data from Resor's Bridge cross section, June 2005 to October 2006: mean daily temperatures for Fish Creek, piezometers, and soil; hourly temperature in Resor's Spring; stage in Fish Creek; and water levels in center piezometer.

29. Stage in Fish Creek and mean daily and hand-measured water levels in piezometers, Resor's Bridge cross section

30. Data from Wilson cross section, June 2005 to October 2006: mean daily temperatures for Fish Creek, piezometers, and soil; stage in Fish Creek; and water levels in center piezometer.

31. Stage in Fish Creek and mean daily and hand-measured water levels in piezometers, Wilson cross section

\section{Tables}

1. Name and location of continuous temperature instruments at the Teton Village, Resor's Bridge, and Wilson cross sections on Fish Creek . .16

2. Summary of hydraulic parameters used in final calibrated VS2DH models for each cross section

3. Summary of estimated flux from groundwater to surface water across the streambed boundary in models of Fish Creek cross sections 


\section{Conversion Factors and Datum}

\begin{tabular}{|c|c|c|}
\hline Multiply & By & To obtain \\
\hline \multicolumn{3}{|c|}{ Length } \\
\hline centimeter $(\mathrm{cm})$ & 0.3937 & inch (in) \\
\hline meter $(\mathrm{m})$ & 3.281 & foot $(\mathrm{ft})$ \\
\hline kilometer (km) & 0.6214 & mile (mi) \\
\hline \multicolumn{3}{|c|}{ Area } \\
\hline square kilometer $\left(\mathrm{km}^{2}\right)$ & 0.386 & square mile $\left(\mathrm{mi}^{2}\right)$ \\
\hline \multicolumn{3}{|c|}{ Volume } \\
\hline cubic meter $\left(\mathrm{m}^{3}\right)$ & 35.31 & cubic foot $\left(\mathrm{ft}^{3}\right)$ \\
\hline cubic meter $\left(\mathrm{m}^{3}\right)$ & 0.0008107 & acre-foot (acre-ft) \\
\hline \multicolumn{3}{|c|}{ Flow rate } \\
\hline cubic meter per second $\left(\mathrm{m}^{3} / \mathrm{s}\right)$ & 35.31 & cubic foot per second $\left(\mathrm{ft}^{3} / \mathrm{s}\right)$ \\
\hline cubic meter per month ( $\mathrm{m}^{3} /$ month) & 0.0008107 & acre-foot per month (acre-ft/month) \\
\hline cubic meter per day $\left(\mathrm{m}^{3} / \mathrm{d}\right)$ & 35.31 & cubic foot day $\left(\mathrm{ft}^{3} / \mathrm{d}\right)$ \\
\hline \multicolumn{3}{|c|}{ Hydraulic conductivity } \\
\hline meter per second $(\mathrm{m} / \mathrm{s})$ & 3.281 & foot per second $(\mathrm{ft} / \mathrm{s})$ \\
\hline \multicolumn{3}{|c|}{ Hydraulic gradient } \\
\hline meter per kilometer $(\mathrm{m} / \mathrm{km})$ & 5.27983 & foot per mile ( $\mathrm{ft} / \mathrm{mi})$ \\
\hline
\end{tabular}

Temperature in degrees Celsius $\left({ }^{\circ} \mathrm{C}\right)$ may be converted to degrees Fahrenheit $\left({ }^{\circ} \mathrm{F}\right)$ as follows:

$$
{ }^{\circ} \mathrm{F}=\left(1.8 x^{\circ} \mathrm{C}\right)+32
$$

Vertical coordinate information is referenced to the National Geodetic Vertical Datum of 1929 (NGVD 29).

Horizontal coordinate information is referenced to the North American Datum of 1983 (NAD 83).

Altitude, as used in this report, refers to distance above the vertical datum.

Water year is the 12-month period October 1 through September 30 and is designated by the calendar year in which it ends. Thus, the water year ending September 30, 2005, is called water year 2005.

\section{Acronyms}

PVC polyvinyl chloride

2-D two-dimensional

USGS U.S. Geological Survey 


\title{
Characterization of Interactions between Surface Water and Near-Stream Groundwater along Fish Creek, Teton County, Wyoming, by Using Heat as a Tracer
}

\author{
By Cheryl A. Eddy-Miller, Jerrod D. Wheeler, and Hedeff I. Essaid
}

\begin{abstract}
Fish Creek, a tributary of the Snake River, is about 25 river kilometers long and is located in Teton County in western Wyoming near the town of Wilson. Local residents began observing an increase in the growth of algae and aquatic plants in the stream during the last decade. Due to the known importance of groundwater to surface water in the area, the U.S. Geological Survey (USGS), in cooperation with the Teton Conservation District, conducted a study to characterize the interactions between surface water and near-stream groundwater along Fish Creek.

The study has two main objectives: (1) develop an improved spatial and temporal understanding of water flow (fluxes) between surface water and groundwater, and (2) use a two-dimensional groundwater-flow and heat-transport model to interpret observed temperature and hydraulic-head distributions and to describe groundwater flow near Fish Creek. The study is intended to augment hydrologic information derived from previously published results of a seepage investigation on Fish Creek. Seepage measurements provide spatially averaged gains and losses over an entire reach for one point in time, whereas continuous temperature and water-level measurements provide continuous estimates of gain and loss at a specific location.
\end{abstract}

Stage, water-level, and temperature data were collected from surface water and from piezometers completed in an alluvial aquifer at three cross sections on Fish Creek at Teton Village, Resor's Bridge, and Wilson from October 2004 to October 2006. The flow and energy (heat) transport model VS2DH was used to simulate flow through the streambed of Fish Creek at the Teton Village cross section from April 15 to October 14, 2006, (183 recharge periods) and at the Resor's Bridge and Wilson cross sections from June 6, 2005, to October 14, 2006 (496 recharge periods). A trial-and-error technique was used to determine the best match between simulated and measured data. These results were then used to calibrate the cross-sectional models and determine horizontal and vertical hydraulic conductivities. The fluxes of groundwater into the stream or fluxes of stream water into the alluvial aquifer were estimated by using the calibrated VS2DH model for each cross section.

Results of the simulations indicated that surface water/ groundwater interaction and hydraulic properties were different at the three cross sections. At the most upstream cross section, Teton Village, Fish Creek flowed intermittently and continually gained relatively large quantities of water from April through September. During other times of the year, the stream was dry near the cross section. Saturated hydraulic conductivity set at $1 \times 10^{-4} \mathrm{~m} / \mathrm{s}$ in both the horizontal and vertical directions resulted in the best match between simulated and measured temperatures. The Resor's Bridge cross section, about midway between the other two cross sections, was near the point where perennial flow begins. At this cross section, the stream gained water from groundwater during high flow in late spring and summer, was near equilibrium with groundwater during August and September, and lost water to groundwater during the remainder of the year. Horizontal hydraulic conductivity set at $5 \times 10^{-5} \mathrm{~m} / \mathrm{s}$ and vertical hydraulic conductivity set at $1 \times 10^{-5} \mathrm{~m} / \mathrm{s}$ resulted in the best match between simulated and measured temperatures. The Wilson cross section, the most downstream site, was at USGS streamflow-gaging station 13016450. This part of the stream is perennial and was almost always gaining a small volume of water from groundwater. Saturated hydraulic conductivity set at $1 \times 10^{-4} \mathrm{~m} / \mathrm{s}$ in the horizontal direction and at $5 \times 10^{-6} \mathrm{~m} / \mathrm{s}$ in the vertical direction resulted in the best match between simulated and measured temperatures.

Quantitative values of the flux from groundwater into surface water were estimated by using VS2DH and ranged from 1.1 to 6.6 cubic meters per day $\left(\mathrm{m}^{3} / \mathrm{d}\right)$ at the Teton Village cross section, from -3.8 to $7.4 \mathrm{~m}^{3} / \mathrm{d}$ at the Resor's Bridge cross section, and from 0.1 to $1.2 \mathrm{~m}^{3} / \mathrm{d}$ at the Wilson cross section. Monthly fluxes ranged from 16 to 199 cubic meters per month ( $\mathrm{m}^{3} /$ month) at the Teton Village cross section, from -114 to $222 \mathrm{~m}^{3} /$ month at the Resor's Bridge cross section, and from 3 to $33 \mathrm{~m}^{3} /$ month at the Wilson cross section.

Specifically, the Teton Village reach is strongly influenced by two factors: (1) snowmelt in the basin directly upstream and (2) large fluctuations in the water table. The 
Resor's Bridge reach is influenced by a combination of (1) a rise in groundwater level likely due to both infiltration of valley snowmelt and recharge to the alluvial aquifer along the west bank from the higher stage of the Snake River, (2) a snowmelt pulse from the mountain range to the west, and (3) recharge from irrigation water infiltration. Summer streamflows in the Wilson reach are maintained by streamflow in the upper part of the creek, tributary inflows, and a small, constant input of groundwater. Winter streamflows in the Wilson reach have similar inputs, except that tributary inflows are minimal.

The qualitative patterns of gain and loss are in general agreement with qualitative results from previous investigations. However, this study provides quantitative information that can be used for future studies of Fish Creek, such as nutrient budgets, simulation of surface-water and groundwater flow, and simulation of surface water/groundwater interactions in the southwestern area of the Jackson Hole valley.

\section{Introduction}

Fish Creek, an approximately 25-kilometer $(\mathrm{km})$ long tributary of the Snake River, is located in Teton County in western Wyoming near the town of Wilson (figs. 1 and 2). Fish Creek's drainage area includes part of the southern extent of the Teton Range and the southwestern part of the Jackson Hole valley, and is 183 square kilometers $\left(\mathrm{km}^{2}\right)$ at the U.S. Geological Survey streamflow-gaging station, Fish Creek at Wilson, Wyoming (station 13016450; fig. 2; Swanson and others, 2002).

Studies of the Snake River west bank (located between the Snake River and the western edge of the Jackson Hole valley (fig. 2) have shown that streamflow in Fish Creek responds quickly to changes in groundwater levels (Nelson Engineering, 1992; Hinckley Consulting and Jorgensen Engineering, 1994; Wyoming State Engineer's Office, 2005). The groundwater table in the alluvial aquifer near Fish Creek can rise due to natural recharge, recharge from local flood irrigation, injection of tertiary treated sewage, or recharge from infiltration through the streambed of ditches, tributaries such as Lake Creek (a diversion from the Snake River; Nelson Engineering, 1992) or the Snake River (Wyoming State Engineer's Office, 2005). Fish Creek inflows can include spring flows, irrigation diversions from area rivers and streams, irrigation return flows, and tributary streamflows.

Local residents began observing an increase in the growth of algae and aquatic plants in Fish Creek during the last decade. To more fully understand the hydrologic system and the possible relation to aquatic life in the stream, the U.S. Geological Survey (USGS), in cooperation with the Teton Conservation District, conducted a study to determine the interaction of surface water and groundwater along Fish Creek.

The first part of the study, completed in 2004, was a seepage investigation in which streamflow was measured in six reaches of Fish Creek to estimate the magnitude of gains and losses (Wheeler and Eddy-Miller, 2005). The seepage measurements, conducted during August and November (to represent relatively high-flow and base-flow conditions, respectively), determined that the stream is either gaining water from groundwater or in near-equilibrium with the groundwater (fig. 3), depending on the time of year and location along the stream.

The second part of the study is intended to augment hydrologic information derived from the previously published seepage investigation of Fish Creek (Wheeler and EddyMiller, 2005). It has two main objectives: (1) develop an improved spatial and temporal understanding of water flow (fluxes) between surface water and groundwater, and (2) use simulations from a two-dimensional groundwater-flow and heat-transport model to interpret measured temperature and hydraulic-head distributions and to describe groundwater flow near Fish Creek. Seepage measurements provide spatially averaged gains and losses over an entire reach for one point in time, whereas continuous temperature and water-level measurements provide continuous estimates of gain and loss at a specific location. Stage, water-level, and temperature data were collected from surface water and from piezometers completed in the alluvial aquifer at three cross sections on Fish Creek. These data were used to calibrate cross-sectional, two-dimensional (2-D) VS2DH models (Healy and Ronan, 1996) of flow into or out of the stream at three locations. Model simulation results were used to estimate aquifer properties, such as the effective hydraulic conductivity and the flux of groundwater into the stream or flux of stream water into the alluvial aquifer.

\section{Purpose and Scope}

The purpose of this report is to describe interactions between surface water and near-stream groundwater along Fish Creek by using temperature (as a natural tracer), stage, and water-level data collected from October 2004 to October 2006 from three cross sections on the creek. The interactions are qualitatively described as the direction and relative magnitude of flow based on measured temperature and water-level data and are quantitatively described as fluxes between surface water and groundwater based on the model simulations of flow and heat transport. The simulated fluxes were compared with the streamflow gains and losses determined during the 2004 seepage investigation.

\section{Acknowledgements}

The authors gratefully acknowledge the generous assistance of landowners near Fish Creek who provided access to their property for this study. The authors also acknowledge assistance from Brian Remlinger and Dan Leemon, Teton Conservation District; Bill Resor, Snake River Associates; and Rick Healy and Suzanne Roberts, U.S. Geological Survey. 


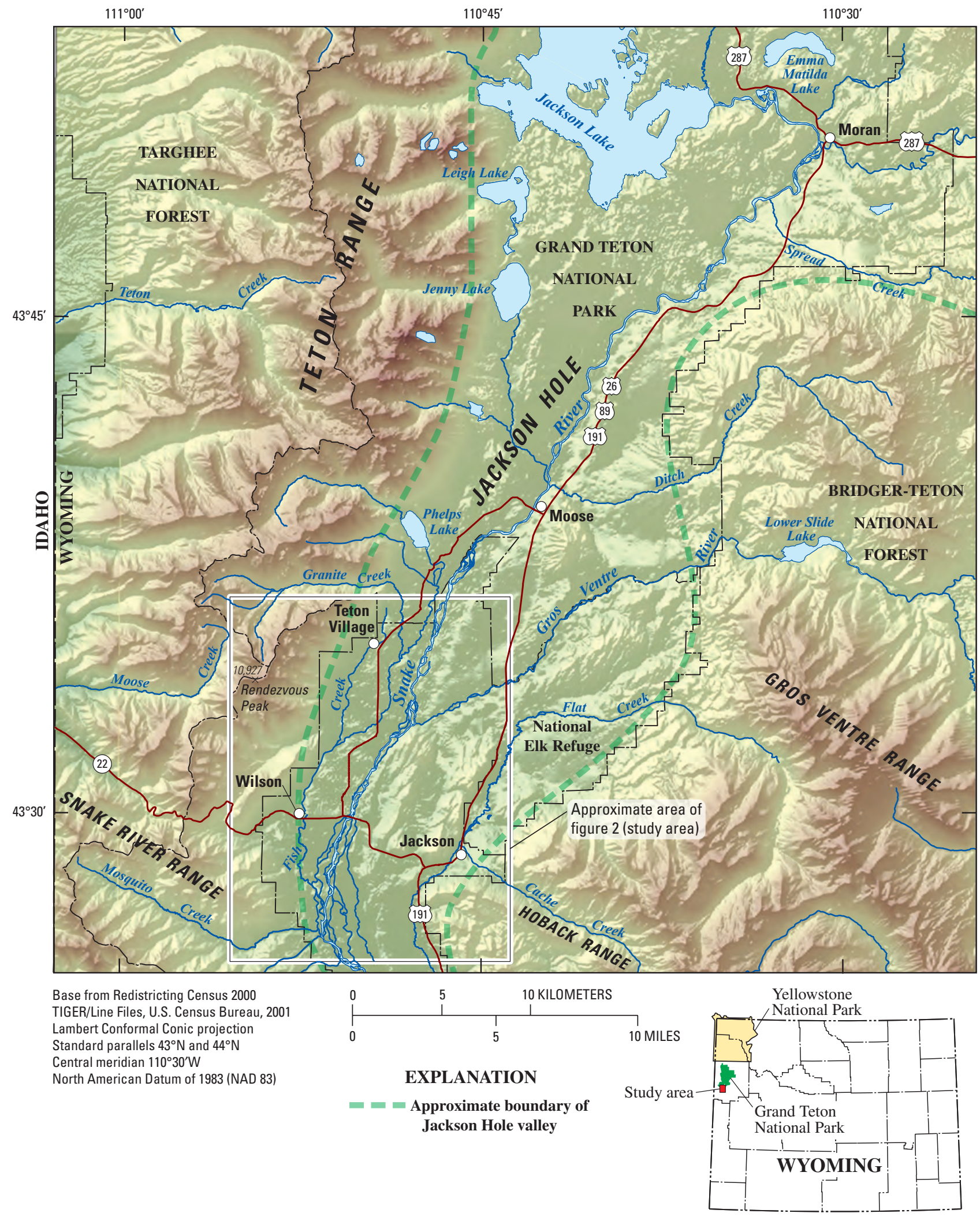

Figure 1. Location of Fish Creek as part of the Jackson Hole valley, Wyoming. 


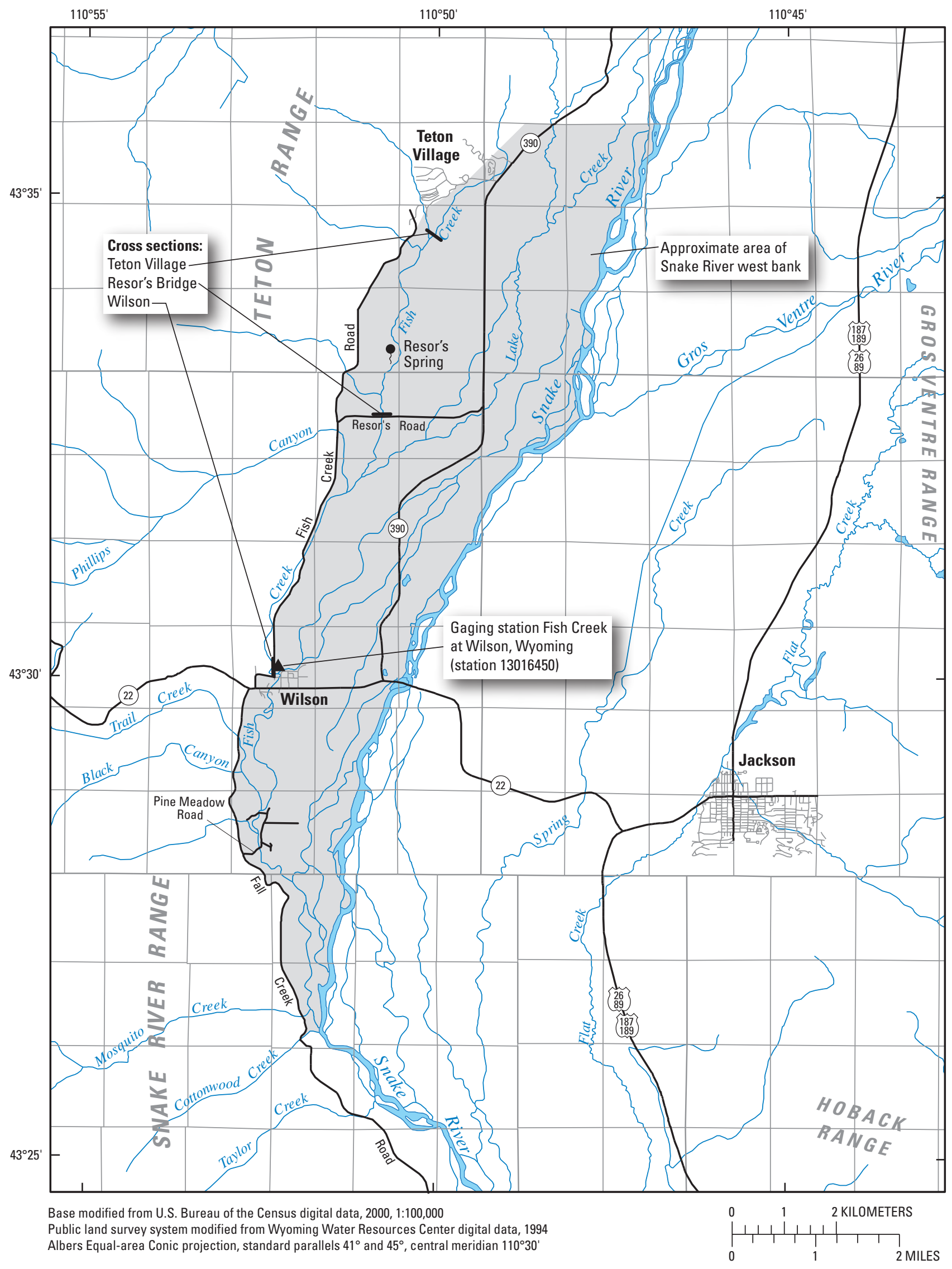

Figure 2. Locations of three piezometer cross sections and miscellaneous thermal measurement site on and near Fish Creek, Wyoming. 
A. August

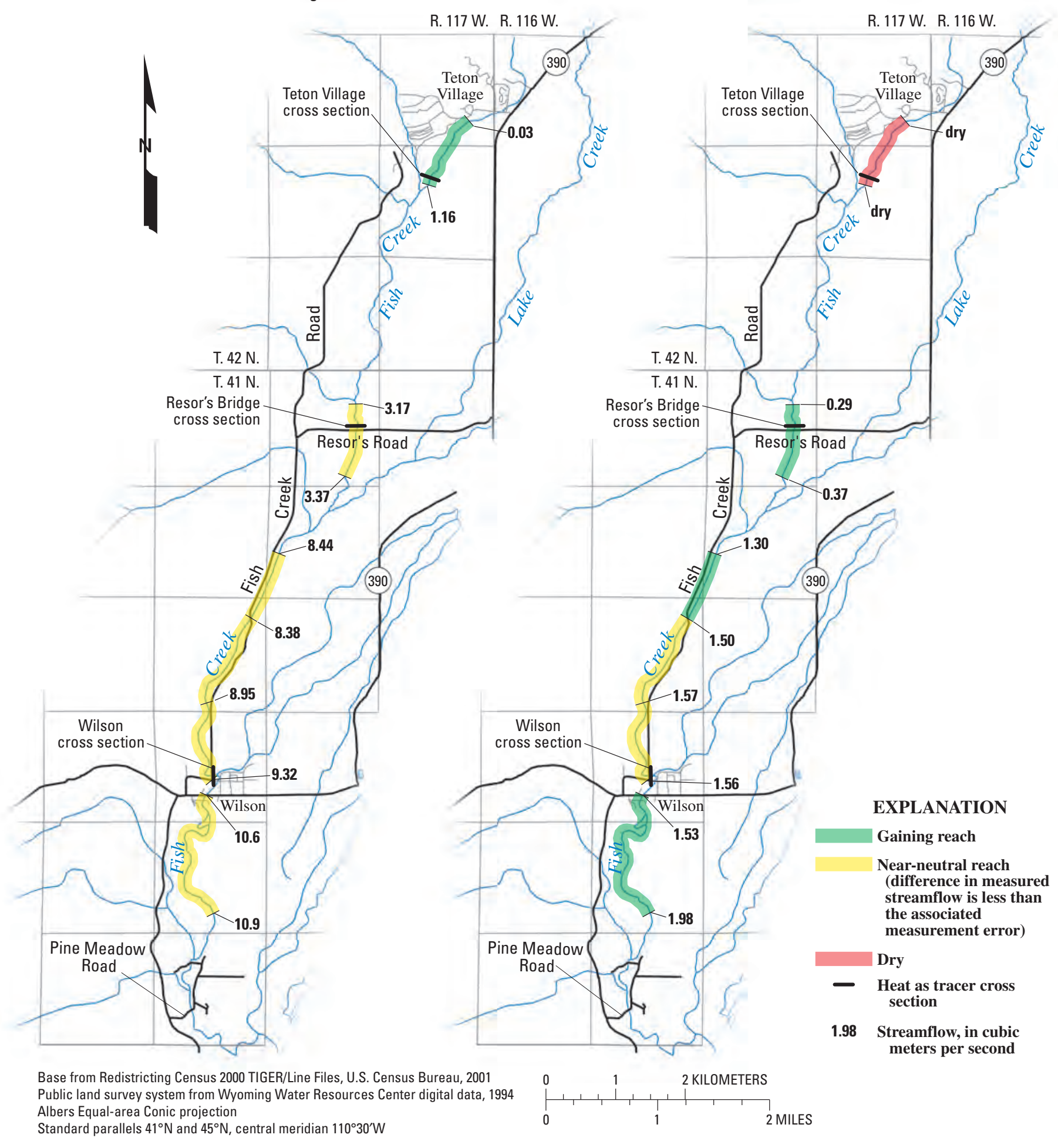

Figure 3. Streamflow at seepage investigation sites and identification of reaches with and without gains from groundwater, Fish Creek, Wyoming. A, August 2004. B, November 2004 (from data in Wheeler and Eddy-Miller, 2005). 
Jim Constantz, Rod Caldwell, and Janet Carter, U.S. Geological Survey, are acknowledged for their excellent reviews of report drafts.

\section{Description of Study Area}

Teton County is experiencing rapid growth and development in the west bank area of the Snake River. Nelson Engineering (1992) estimated that 1,670 residential dwellings were in the west bank area in 1992. Between 1992 and 2007, an additional 640 dwellings were constructed in the west bank area (Jennifer Bodine, Teton County Planning and Development, written commun., 2008). The alluvial aquifer supplies water to area residents by way of a water-supply system or individual wells. Effluent from most of these residents and businesses is discharged into the alluvial aquifer through sewage treatment plants or septic systems. The exception is the town of Wilson, whose effluent is piped to the town of Jackson's waste disposal system. Multiple anthropogenic activities exist in the watershed including a ski area, golf courses, cattle grazing, and irrigation associated with agricultural and aesthetic uses. Altitudes in the study area range from approximately 1,875 meters (m) at the Wilson gaging station on Fish Creek to about 3,200 m at the summit of Rendezvous Peak.

\section{Climate}

The study area is semiarid and has cold winters and warm summers. Mean temperatures and annual precipitation vary with changes in season and altitude. Mean monthly temperatures at the Moose, Wyo., climate station ranged from -10.3 degrees Celsius $\left({ }^{\circ} \mathrm{C}\right)$ in January to $16.0^{\circ} \mathrm{C}$ in July during the period 1958-2007 (National Climatic Data Center, 2009). Mean temperatures decrease with increasing altitude. Mean annual precipitation near the study area, in the form of rain and snow, ranges from 54 centimeters $(\mathrm{cm})$ at the altitude of 1,960 m near Moose, Wyo., (National Climatic Data Center, 2009) to more than $178 \mathrm{~cm}$ in the Teton Range at altitudes above 3,000 m (Oregon Climate Service, 2008). At the Phillips Bench SnoTel station $(2,500 \mathrm{~m})$, approximately $5 \mathrm{~km}$ westsouthwest of Resor's Bridge, the mean annual precipitation for 1971-2000 was $112 \mathrm{~cm}$ (Natural Resources Conservation Service, 2008).

Daily mean temperatures at the Moose, Wyo., station ranged from 22.5 to $-24.5^{\circ} \mathrm{C}$ during June 1,2005 , to October 1, 2006 (National Climatic Data Center, 2009). During this period, maximum temperatures exceeded $30.0^{\circ} \mathrm{C}$ in July of 2005 and 2006, and minimum temperatures fell below $-30.0^{\circ} \mathrm{C}$ in December 2005 and February 2006 (fig. 4). Precipitation data collected at the Moose, Wyo., station during the study period amounted to a cumulative $80.5 \mathrm{~cm}$ (National Climatic Data Center, 2009).

\section{Hydrology}

The primary river and streams in the study area include the Snake River in the central part; Fish Creek, which is west of the Snake River and flows along the western boundary of the Jackson Hole valley; and Lake Creek, a tributary to Fish Creek in the northern part of the study area (fig. 1). The Snake River has a large braided channel and its flow is influenced by regulation from Jackson Lake Dam, by levees that result in seasonal increases in stream stage, and streambed infiltration. The Snake River and Fish Creek flow from north to south on the surface of the alluvial plain; in between the two are multiple intermittent irrigation channels, including Lake Creek, an irrigation-augmented natural channel. Flow in Lake Creek is from natural channel flow, diversions from the Snake River and diversions from Granite Creek - a tributary to the Snake River immediately north of the study area. Lake Creek essentially is an intermittent tributary that joins Fish Creek approximately halfway between Teton Village and Wilson (fig. 2). Several intermittent and perennial tributaries also flow directly off the steep mountain front, or through incised canyons, into Fish Creek from the west along the entire study reach.

Fish Creek has a relatively stable channel morphology and has relatively minor sinuosity and meandering along most of its length upstream from Wilson. The upper reach of Fish Creek, directly downstream from Teton Village, was engineered from a straight channel to a meandering channel predominantly by the end of 2004. Fish Creek has a small drainage area and channel-bed material composed of sand, gravel, and cobble. It also has a controlled flow regime and lacks substantial flooding due primarily to the levees and regulation of the Snake River.

Flows in Fish Creek are influenced by several factors and vary along the study reach. Previous studies have shown a correlation between groundwater levels in the alluvial aquifer and streamflows in Fish Creek and the Snake River (Wyoming State Engineer's Office, 2005). The Snake River flows at altitudes higher than Fish Creek for much of its length and contributes water to the alluvial aquifer due to the downward tilt of the valley floor to the west, which helps create a hydraulic gradient in a southwesterly direction (Nelson Engineering, 1992; Wyoming State Engineer's Office, 2005). A groundwater study of the unconfined alluvial aquifer in the area between the Snake River and Fish Creek showed a connection between the two streams through a groundwater gradient with higher hydraulic head near the Snake River and lower hydraulic head near Fish Creek (Wyoming State Engineer's Office, 2005).

Streamflow data have been collected since 1994 at the Fish Creek at Wilson gaging station (station number 13016450; U.S. Geological Survey, 2008). Data for this period show that the stream at the station is rarely covered in ice (U.S. Geological Survey, 2008), indicating groundwater inflow upstream from or at the station during the winter months. Streamflow data from the station show that during water year 2005, the peak flows occurred in late June, later 


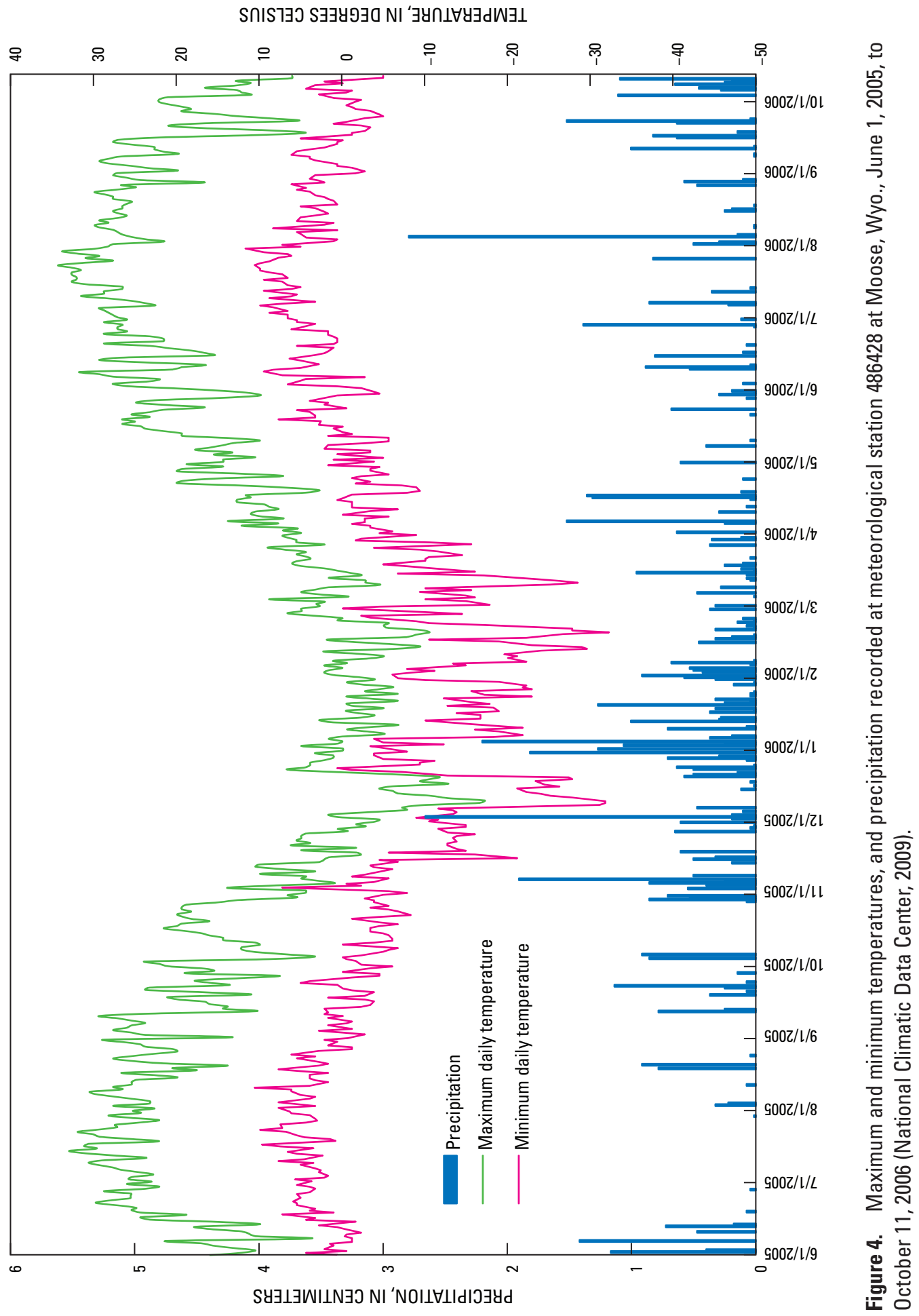


than the 13-year (1994-2006) median (fig. 5); however, the cumulative streamflow for the year (the volume of water that passed by the station) was near the 13-year mean for the site (fig. 6). During water year 2006, peak flows were higher than the 13-year median (fig. 5) and cumulative streamflow was higher than the 13-year mean (fig. 6), likely due in part to the above-normal snowpack in the area during the 2005-06 winter (Natural Resources Conservation Service, 2008).

\section{Geology}

The geology within the study area is structurally complex and consists of diverse strata ranging from Precambrian-era basement rocks to Quaternary-era unconsolidated surficial deposits (fig. 7). The study area lies within the Jackson Hole structural basin, a folded and faulted downwarp of deposits 1,200 to $2,100 \mathrm{~m}$ thick, generally bounded by the Teton Range to the west and the anticlinal uplifts of the Gros Ventre (fig. 1) and Washakie (not on figure) Ranges to the east (Nolan and Miller, 1995). The south boundary of the basin consists of the Snake River (fig.1), Hoback (fig. 1), and Salt River (not on figure) Ranges associated with the Wyoming Thrust Belt. The Teton Range is a north-south trending upthrown faultblock that roughly parallels the Fish Creek and Snake River drainages along the southern part of the valley. The associated Teton Fault zone has caused westward tilting of the basin, which provides dramatic relief of nearly $1,500 \mathrm{~m}$ from the valley floor to the top of the peaks near the study area, and relief of more than 2,100 $\mathrm{m}$ in other parts of the valley.

The steep hillside of the Teton Range immediately west of Fish Creek consists of Precambrian-age metamorphosed gabbro (mafic) and other ultramafic rocks, granitic gneisses, and various granitic rocks with associated pegmatites (Love and others, 1992). Capping the Precambrian rocks are Paleozoic sedimentary sequences including the Flathead Sandstone, Gros Ventre Formation, Gallatin Limestone, Bighorn Dolomite, Darby Formation, and Madison Limestone (Love and others, 1992).

Directly to the east of the study area lie the Gros Ventre Buttes, uplifted normal fault blocks of the previously mentioned Paleozoic sedimentary sequences, coupled with Tertiary-age andesite and basalt volcanic rocks. Quaternaryage surficial deposits occupy most of the drainage basin and are primarily the result of glacial and post-glacial fluvial deposition both in the Snake River Basin and in some of the subsidiary tributary basins. Basin margin alluvial fans, flood-plain alluvium and colluvium, landslide deposits, pediment deposits, and talus deposits also exist in the area. Evidence of glacial moraines and glacial drift deposits of fine silt loess have been indentified in several places in the valley, including parts of the Gros Ventre Buttes (Cox, 1974; Love and others, 1992).

The predominant surficial geology near Fish Creek between the Teton Fault and the Snake River consists of an alluvial plain of unconsolidated clay, silt, sand, gravel, cobbles, and boulders that likely have high depositional variation and are highly permeable. These deposits include alluvium, colluvium, glacial till, and outwash as a result of fluvial deposition and Pleistocene-age valley glaciation (Nolan and Miller, 1995). Geophysical surveys have been done in the area to determine the relative thickness of these Quaternary unconsolidated deposits. Results from a time-domain electromagnetic survey (Nolan and Miller, 1995) indicated that these deposits range in thickness from $120 \mathrm{~m}$ to $730 \mathrm{~m}$ along the Jackson Hole valley and are $140 \mathrm{~m}$ thick near the confluence of the Gros Ventre and Snake Rivers. Results from an audiomagnetotellurics survey (Nolan and others, 1998), primarily conducted in the southern part of the valley and within the study area, indicated that unconsolidated material ranged in thickness from $30 \mathrm{~m}$ in the southernmost part of the valley to $210 \mathrm{~m}$ near the town of Wilson.

\section{Methods}

The use of heat as a natural tracer in conjunction with water-level measurements has been shown to be an effective method for estimating water movement (fluxes) between groundwater and surface water (for example, Constantz and Stonestrom, 2003; Constantz, 2008; Essaid and others, 2008). Determining both water fluxes and hydraulic conductivity requires continuous monitoring of the stream temperature and stage, the sediment temperature at multiple depths below the streambed surface, and the hydraulic head of the groundwater (Su and others, 2004; Essaid and others, 2008). Heat is transported with the flowing water downstream. Heat is also transported through the streambed, primarily through advection with the moving water and conduction through the streambed sediments and interstitial water (Constantz and Stonestrom, 2003; Constantz, 2008). In a gaining reach of stream (where groundwater is discharged to surface water through the streambed), the upward advection of heat due to the higher hydraulic head in the groundwater is coupled with the downward conduction of heat through the streambed sediments (fig. 8). This combination of heat transport dampens the diurnal and seasonal temperature cycle seen in the stream and attenuates the timing of the peaks and valleys of the thermal signal. Conversely, in a losing reach of stream (where surface water is discharged to groundwater through the streambed), heat is transported downward by both conduction and advection. These two mechanisms coupled together create a thermal signal in the groundwater that shows more diurnal fluctuation than that for a gaining reach of the stream (fig. 8).

The flow of water and heat in two dimensions can be evaluated at stream cross sections (perpendicular to the direction of the streamflow) by using piezometers instrumented with thermistors (fig. 8). Qualitative estimates of the direction of flow can be made by comparing the temperatures and stages of the water in the stream to temperatures and water levels 


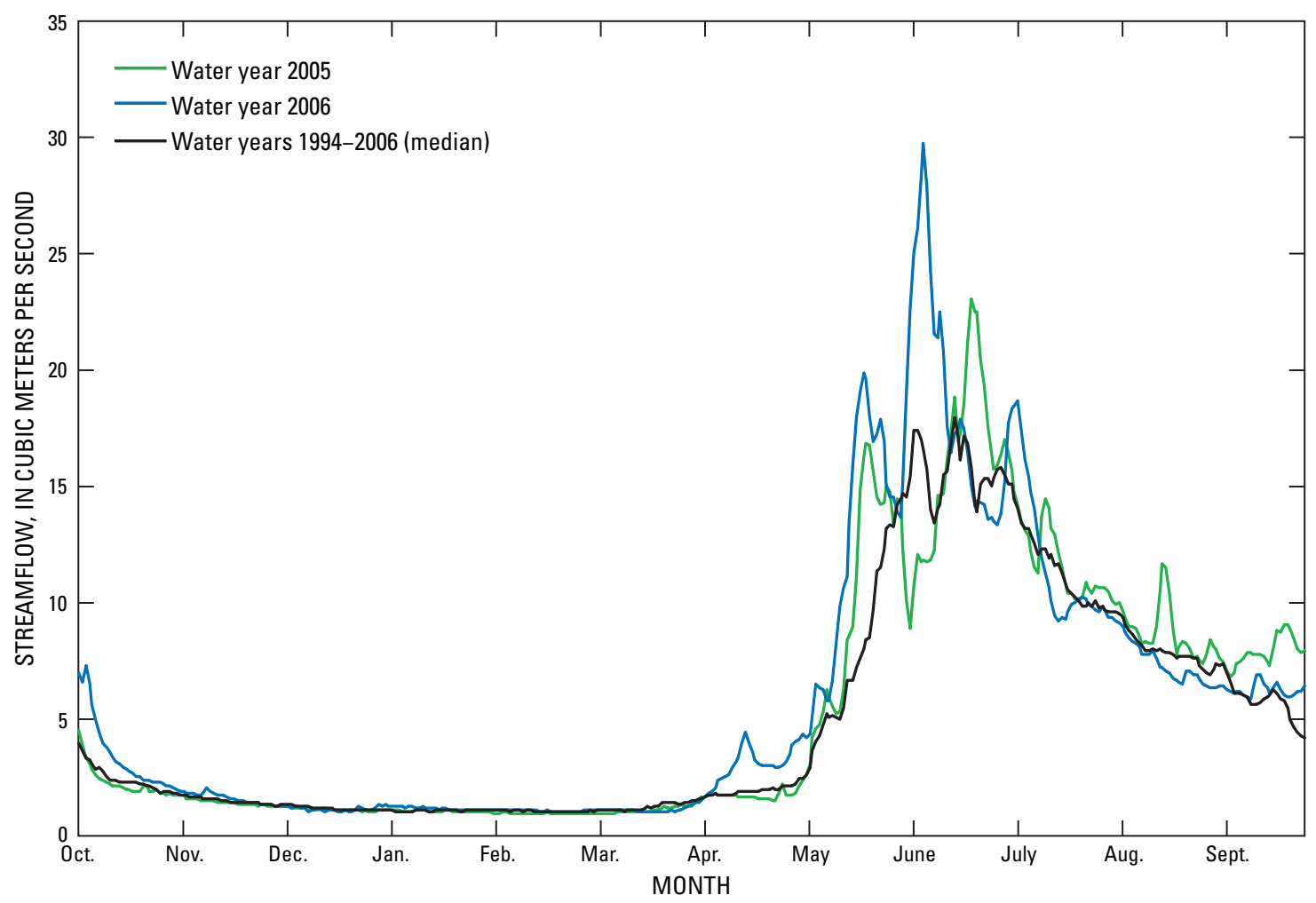

Figure 5. Mean daily streamflow for water years 2005 and 2006, and median streamflow for 1994-2006, Fish Creek at Wilson (station 13016450).

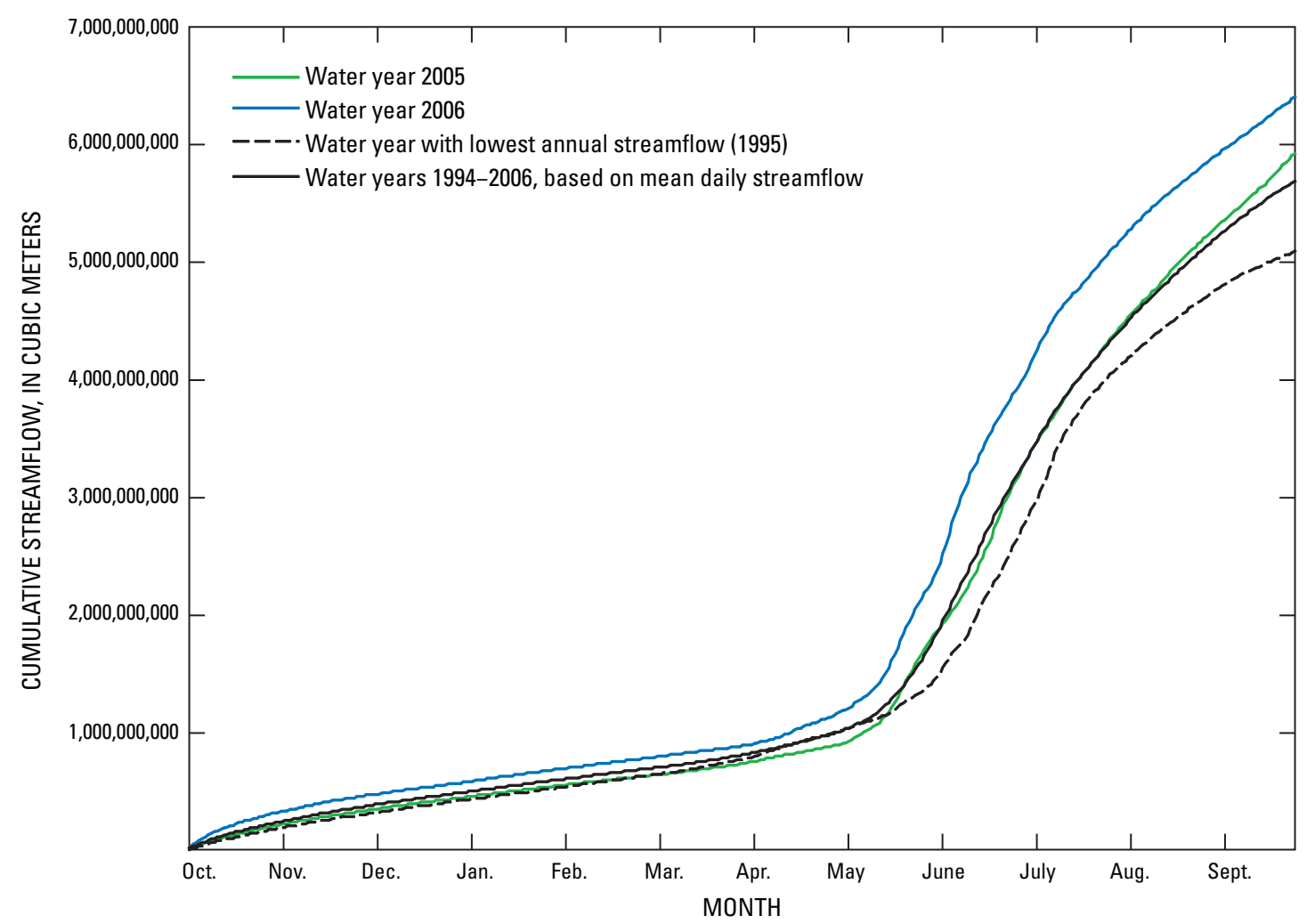

Figure 6. Cumulative streamflow for water years 2005 and 2006, for water year 1995 (lowest annual streamflow), and for 1994-2006 (from mean daily streamflow), Fish Creek at Wilson (station 13016450). 


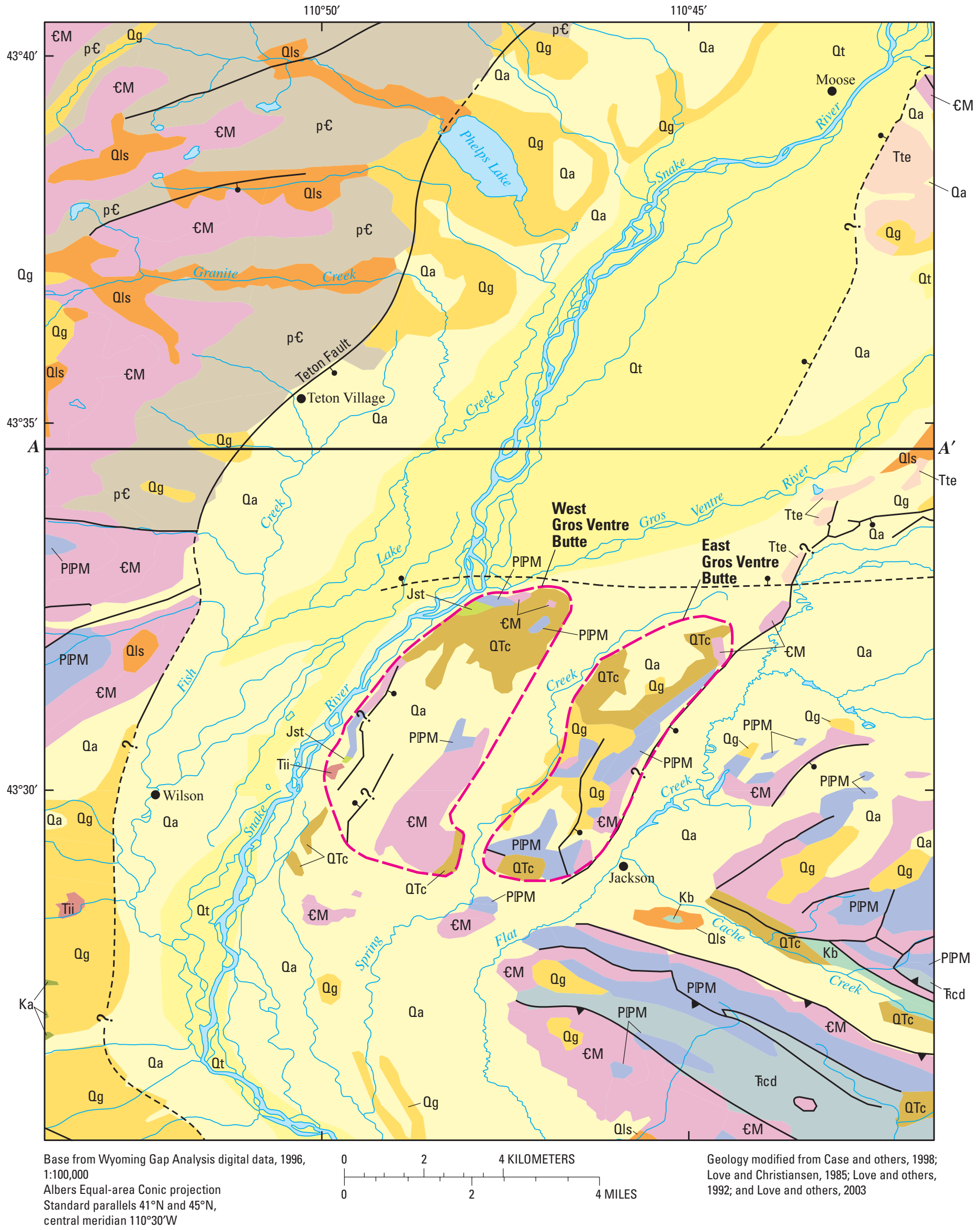

Figure 7. Generalized geology and geologic section in the vicinity of Fish Creek. 


\section{EXPLANATION}

\section{Quaternary unconsolidated deposits}

\begin{tabular}{|c|}
\hline $0 \mathrm{a}$ \\
\hline $0 \mathrm{t}$ \\
\hline $0 \mathrm{~g}$ \\
\hline
\end{tabular}

Alluvium and colluvium

Gravel, pediment, and alluvial fan deposits

Gravel, pediment, talus, and alluvial fan deposits - May include some glacial deposits (fill and outwash) and Tertiary gravels

Qtc Conglomerate

Jackson Hole (Pleistocene or Pliocene)

Qls Landslide deposits

Tertiary sedimentary and igneous rocks

Tte Teewinot Formation

Tii Intrusive and extrusive igneous rocks

\section{Mesozoic and Paleozoic rocks}

\begin{tabular}{|c|}
\hline $\mathrm{Kb}$ \\
\hline $\mathrm{Ka}$ \\
\hline $\mathrm{Jst}$ \\
\hline Rcd \\
\hline \hline $\mathrm{PPM}$ \\
\hline
\end{tabular}

Bacon Ridge Sandstone

Aspen Shale

Stump Formation

Chugwater and Dinwoody Formations

Phosphoria Formation, Wells Formation, Tensleep Sandstone, and Amsden Formation

€M Flathead Sandstone, Gros Ventre Formation, Gallatin Limestone, Bighorn Dolomite, Darby Formation, and Madison Limestone

\section{Precambrian rocks}

p€ Granitic and basaltic rocks, granite gneiss, metasedimentary and metavolcanic rocks, metasedimentary and metamorphosed mafic and ultramafic rocks

\section{- $\_$- _ Fault—Dashed where concealed and/or approximately located Bar and ball on downthrown side \\ Th_ Thrust fault (concealed)—Sawteeth on upper plate \\ $\longrightarrow \quad$ Relative fault movement}

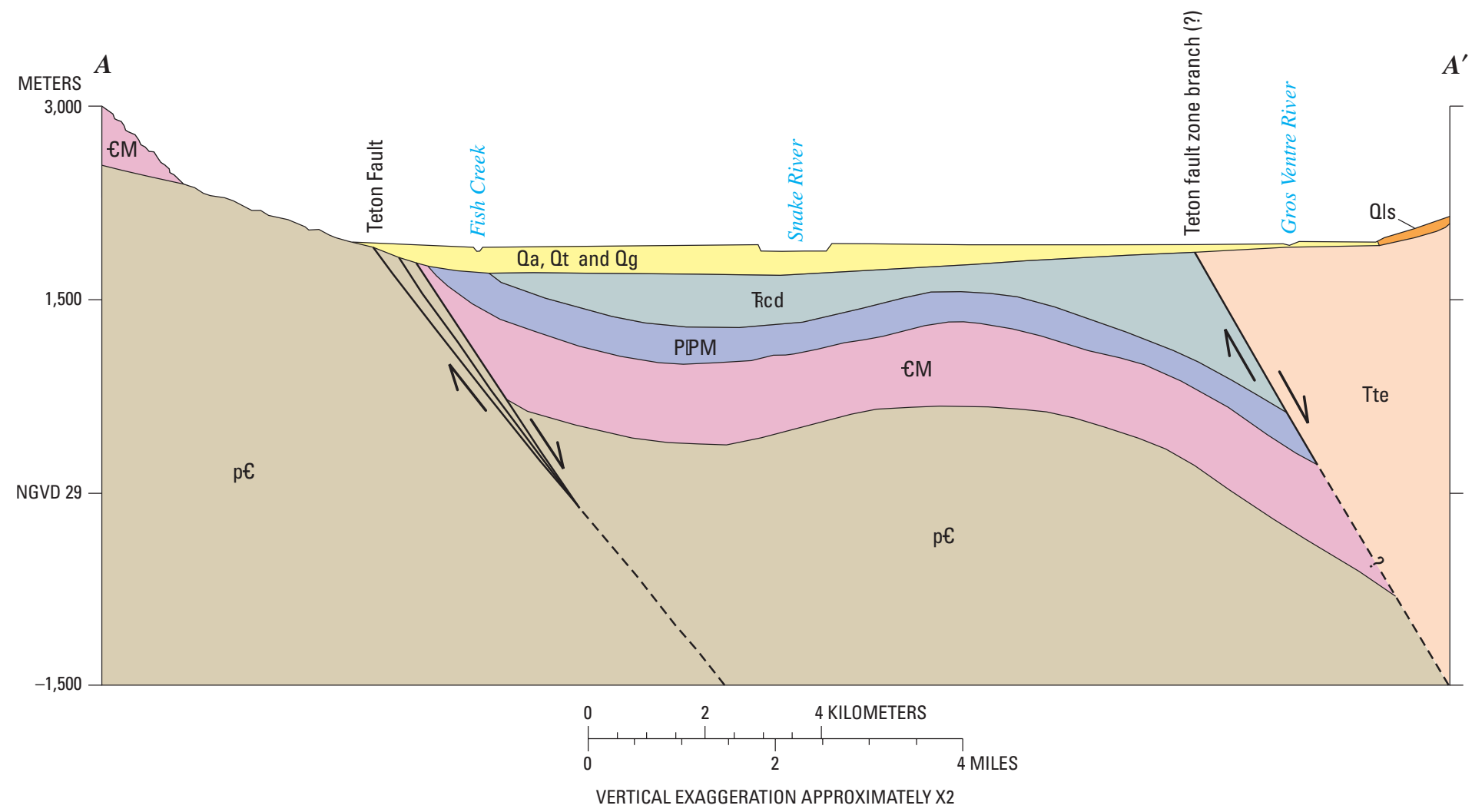

Details of fault and buried strata are approximate and largely diagrammatic. For simplicity, Quaternary deposits are not distinguished in the geologic section. Schematic based on a nearby cross section in Love and others, 2003. 


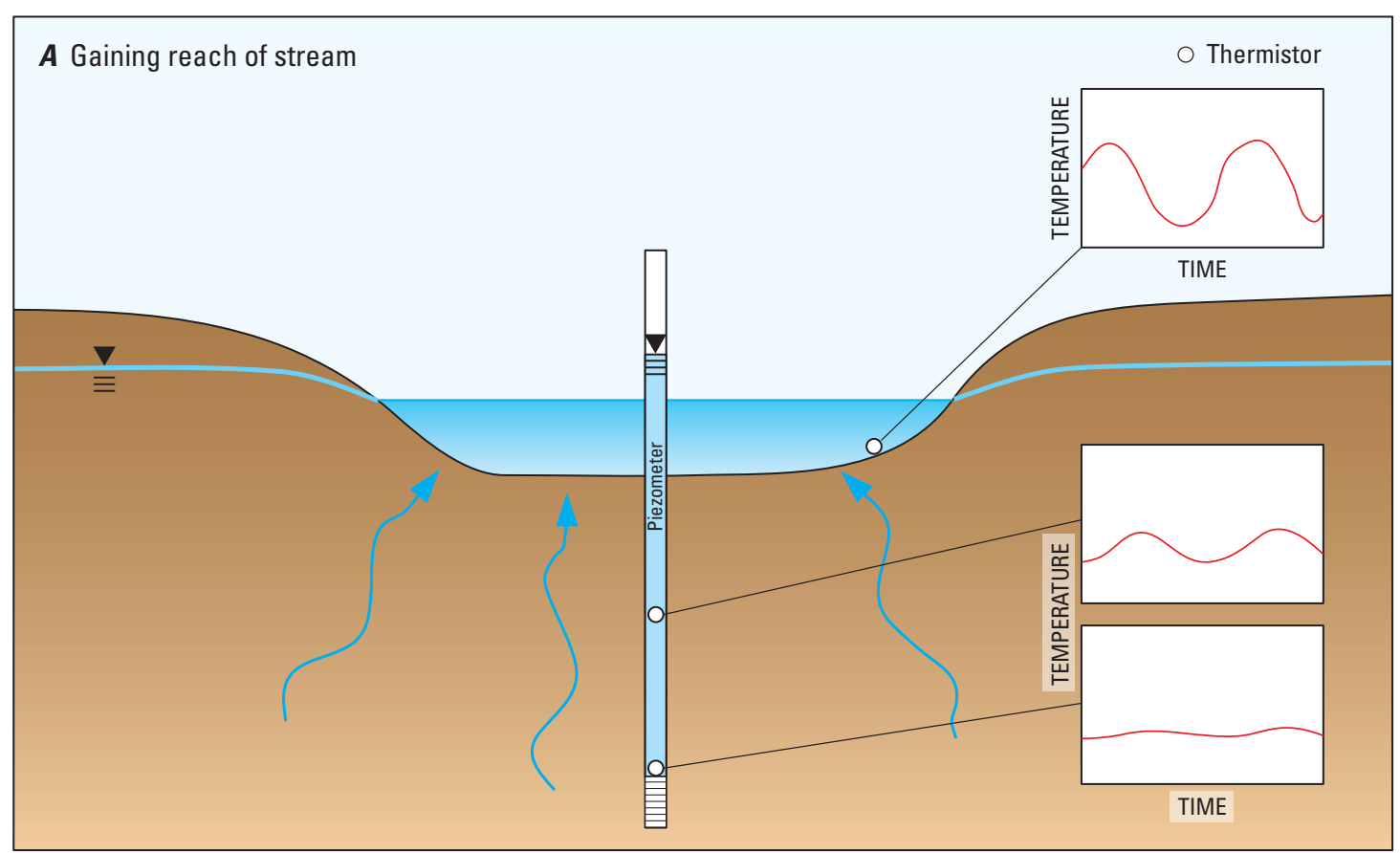

Not to scale

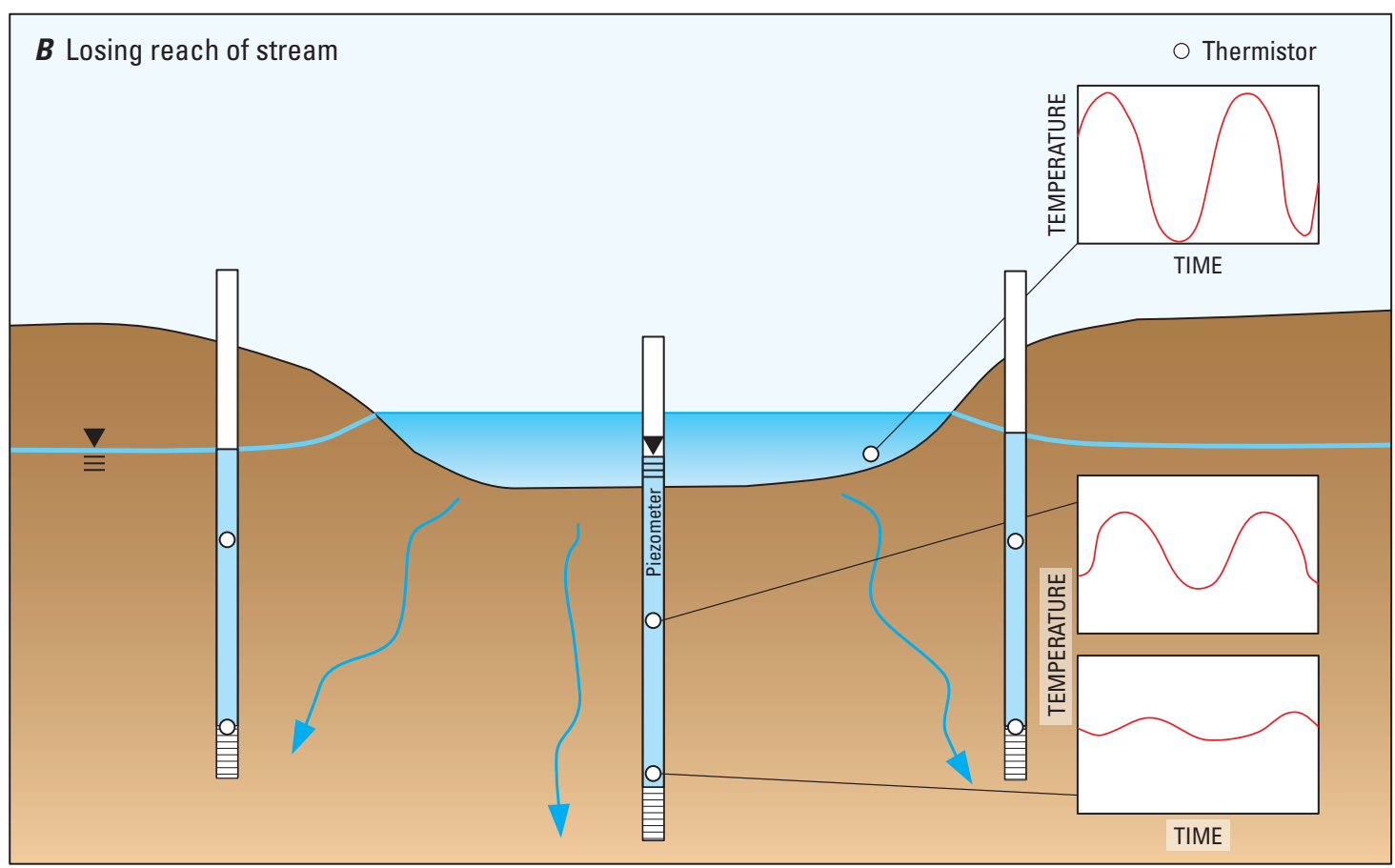

Not to scale

In the gaining reach of stream, the hydraulic head is higher in the groundwater than in the surface water. The upward advection of heat is coupled with the downward conduction of heat through the streambed sediments. This combination of heat transport dampens the diurnal thermal cycle with depth in the streambed and surrounding aquifer. The losing reach of stream has a greater hydraulic head in the stream than in the groundwater. The heat is then transported from the stream to the streambed and surrounding aquifer by both advection and conduction through streambed sediments. The thermal signal dampens with depth, but not as great as in the gaining stream reach. (Schematics modified from Constantz and Stonestrom, 2003.)

Figure 8. Streambed flow and heat transport in a gaining and a losing reach of a stream. $A$, Gaining reach. B, Losing reach. (Schematics modified from Constantz and Stonestrom, 2003.) 
below and adjacent to the streambed. Quantitative estimates of water flux through the streambed to and from the unconfined aquifer can be obtained by comparing simulated and measured sediment temperatures.

Specifically, estimates of streambed flux and hydraulic conductivities can be made by manually matching simulated temperatures from a numerical model that simulates the flow of water and heat through sediments, such as the USGS models VS2DH and SUTRA (Constantz, 2008), with measured streambed temperatures. The 2-D groundwater-flow and heat-transport model VS2DH (Healy, 2008) has been used to simulate water and heat transport in sediment (Constantz and others, 2003; Cox and others, 2007; Essaid and others, 2008) and was used to analyze the data from the Fish Creek cross sections. Flux estimates from the VS2DH model were compared with the streamflow gains and losses determined from the 2004 seepage investigation.

\section{Study Design and Data Collection}

Three streambed cross sections, each instrumented with five piezometers, were delineated at Teton Village, Resor's Bridge, and Wilson (fig. 2) to represent an upstream, midsection, and downstream location, respectively. The upstream site below Teton Village is in a part of the stream that was recently rechannelized (Brian Remlinger, Teton Conservation District, oral commun., 2004). Most of the work changing the stream from a straight channel through a meadow to an engineered, meandering stream was completed in 2004. The Resor's Bridge and Wilson cross sections are on morphologically stable sections of the stream. The Resor's Bridge cross section is approximately where perennial streamflow begins. The downstream cross section was located near the USGS Wilson gaging station (13016450) in order to compare historical and current streamflow information from the gaging station to the data collected for this study.

The piezometers were constructed from $1 \frac{1 / 4-i n c h ~}{(3.2-\mathrm{cm})}$ diameter galvanized pipe with eight, $0.6-\mathrm{cm}$ diameter holes drilled into the bottom of the pipe as screen. The bottom of each threaded pipe was attached to a well point to facilitate installation, and all piezometers were installed by using a fence-post driver. All three cross-section sites had two piezometers on the left bank (representing the eastern side of the channel), one in the center of the channel, and two on the right bank (representing the western side of the channel; figs. 9, 10, and 11). The piezometers on the left bank (labeled 2 and 1) were located $1 \mathrm{~m}$ and $2 \mathrm{~m}$, respectively, from the edge of the primary channel. The piezometers on the right bank (labeled 4 and 5) also were located $1 \mathrm{~m}$ and $2 \mathrm{~m}$, respectively, from the edge of the primary channel. The piezometer in the center of the channel (labeled 3) was completed flush with the channel bed to prevent damage to the piezometer from floating debris and any transported bedload. Piezometers in the center of the channel were capped with water-tight caps. When measuring water levels by hand, field personnel attached a polyvinyl chloride (PVC) riser to the piezometer that extended above the stream level and allowed water levels to stabilize before measuring the groundwater level.

Continuous (hourly) temperature data were collected at two depths in all piezometers, in the soil near the cross section at about a $5-\mathrm{cm}$ depth, and in the stream at all three cross sections beginning in October 2004 using StowAway TidbiT temperature loggers (Onset Computer Corp; table 1). After March 2005, the center (number 3) piezometer at each site was instrumented with a miniTROLL Professional (In-Situ Inc.) to record the temperature at the bottom of the piezometer and continuously record water levels. A miniTROLL Standard (In-Situ Inc.) was installed in the stream immediately next to the piezometer to record stage in the stream. The final instrumentation configurations are shown in figures 9,10 , and 11.

The depth of one piezometer was changed at the Teton Village cross section (fig. 9). Data collected between October 2004 and October 2005 at TV3 in the center of the channel showed that the upward flux of groundwater into the stream was large, creating upward advective heat transport that led to temperature values in thermistor TV3-30 that were almost exactly the same as values in thermistor TV3-90, which reduced the certainty in a flux estimate for this case. Therefore, in October 2005, the TV3 piezometer was extended deeper by $0.3 \mathrm{~m}$ and was thereafter referred to as TV3a. Changes in thermistor locations for this piezometer are noted in table 1 .

Continuous (hourly) temperature data were collected in the stream and at two depths in all piezometers, except TV3a, which had three collection depths between October 2005 and October 2006. Water levels were hand measured during five different hydrologic conditions between October 2004 and October 2006. Initial data analysis showed the need for continuous stage data in the stream and continuous water-level data in at least the center piezometer (number 3 ) in order to characterize the dynamic nature of the flow system. In March 2005, a miniTROLL Standard and a miniTROLL Professional were installed in the stream and in the center piezometer, respectively, at each cross section.

Accurate altitude and location data for each piezometer were needed for developing VS2DH. Differential leveling was used to survey the altitude of each piezometer to an accuracy of $0.001 \mathrm{~m}$ in October 2004 and again in August 2005 to detect potential movement. Additionally, the altitude of the streambed at each cross section was surveyed at $0.3-\mathrm{m}$ intervals across the channel during these same two periods.

\section{Model Design and Calibration}

The flow and energy transport model VS2DH (Healy and Ronan, 1996) and the graphical user interface VS2DI (Hsieh and others, 2000) were used to simulate flow through the streambed of Fish Creek. The 2-D vertical cross sections perpendicular to the direction of streamflow were developed for each monitored cross section. The physical and hydrologic 


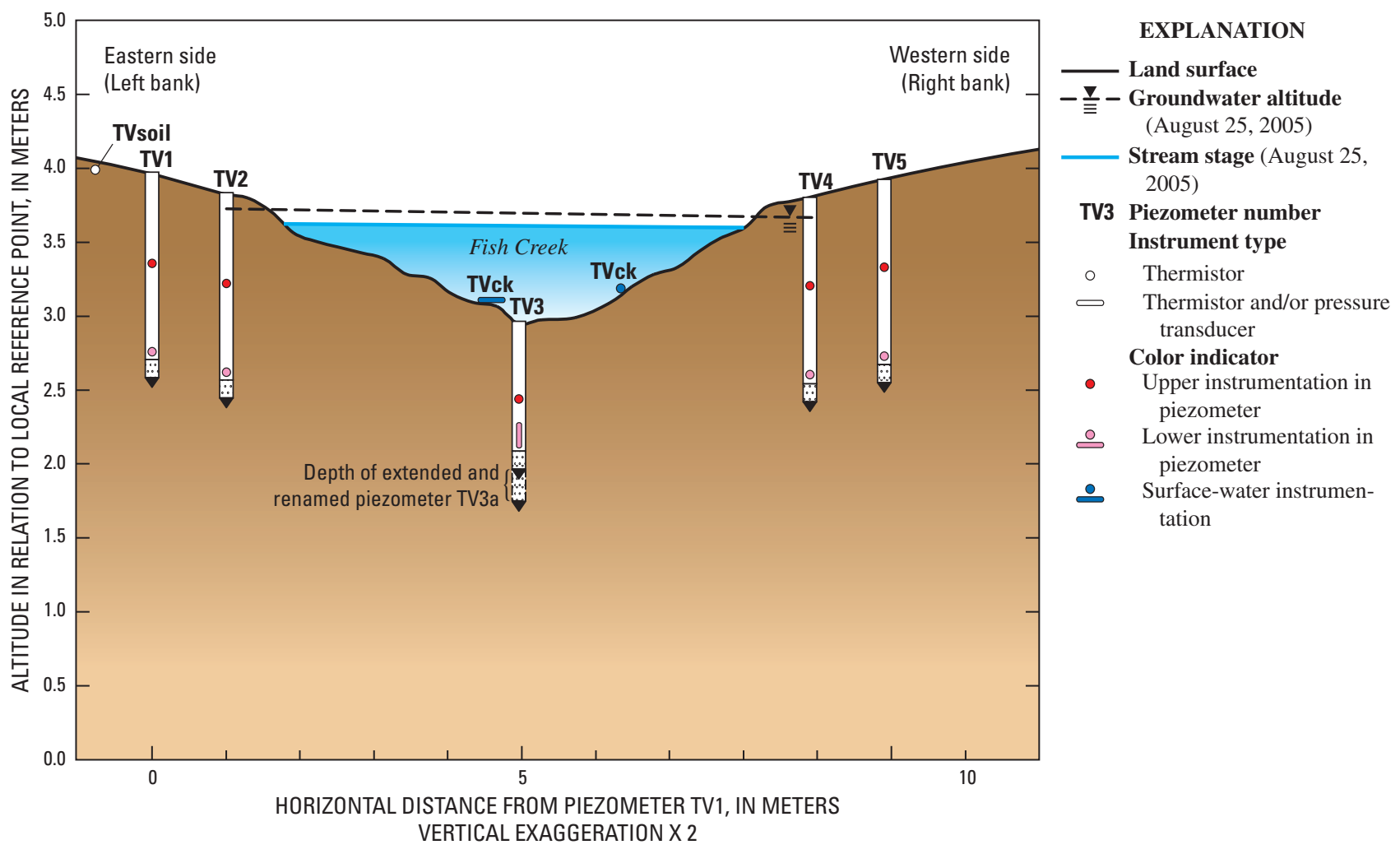

Figure 9. Channel geometry, piezometer network, and thermistor and/or pressure transducer locations at Teton Village cross section. Water-level and stage data for August 25, 2005.

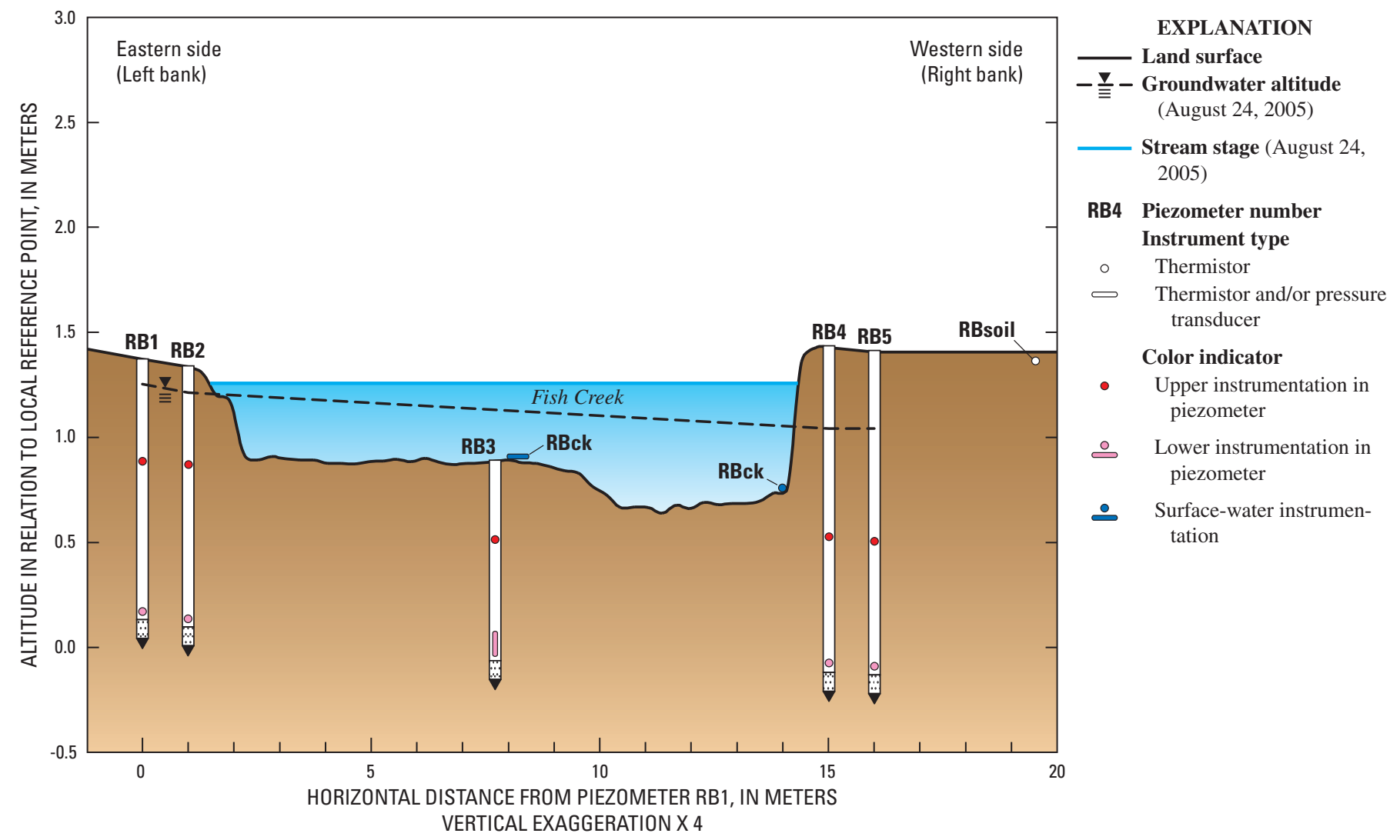

Figure 10. Channel geometry, piezometer network, and thermistor and/or pressure transducer locations at Resor's Bridge cross section. Water-level and stage data for August 24, 2005. 


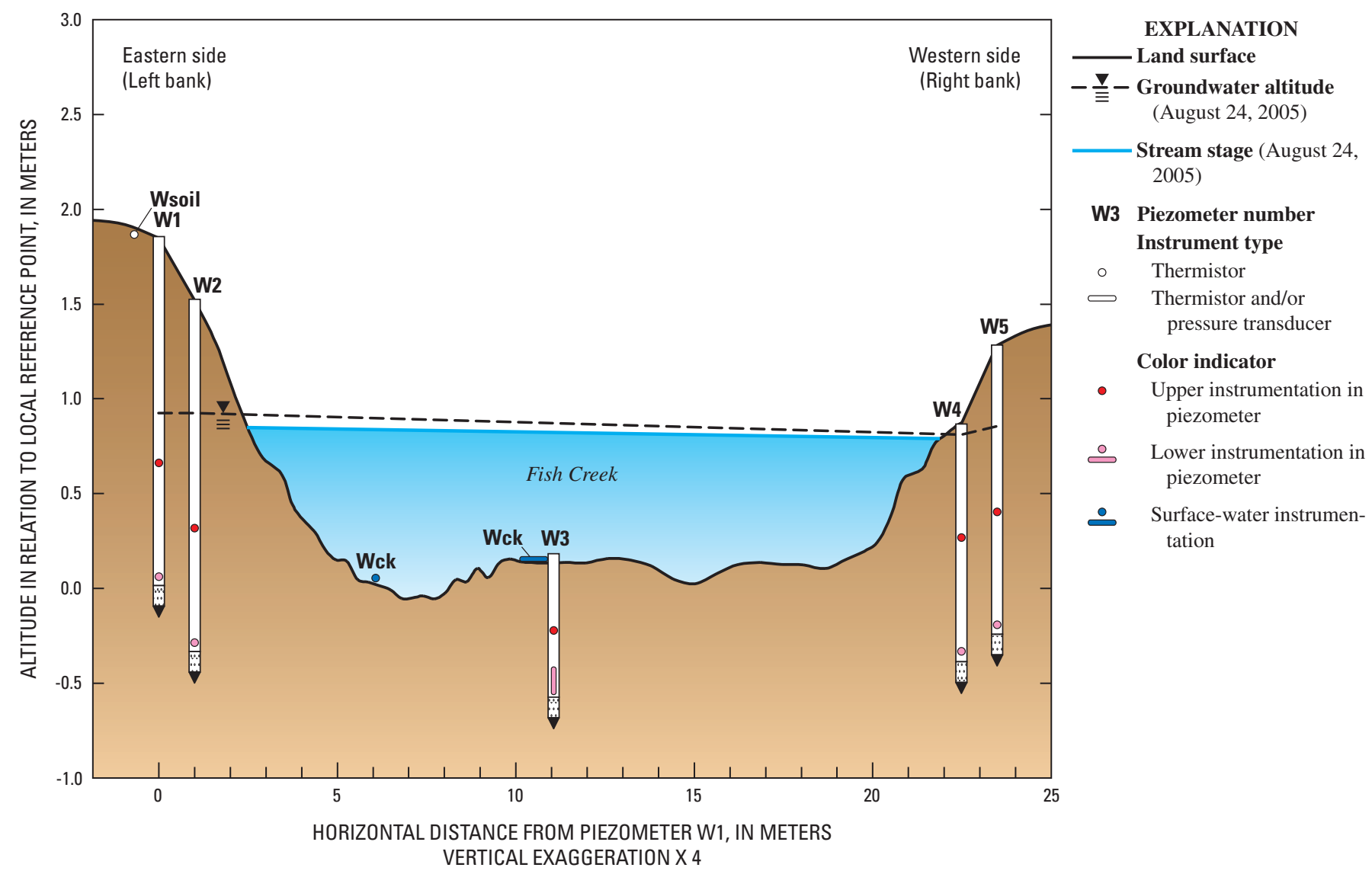

Figure 11. Channel geometry, piezometer network, and thermistor and/or pressure transducer locations at Wilson cross section. Water-level and stage data for August 24, 2005.

setting was characterized by using land surveys and data collected from thermistors and the stream, and from handmeasured water levels in the piezometers at each cross section. The model was designed to have daily recharge periods, and simulation periods were April 15 to October 14, 2006, (183 recharge periods) for the Teton Village cross section, and June 6, 2005, to October 14, 2006, (496 recharge periods) for the Resor's Bridge and Wilson cross sections.

\section{Model Framework and Boundary Conditions}

The design of the VS2DH model involved specifying a model domain and boundary conditions that correspond to the physical system at each cross section (fig. 12). The left- and right-side lateral boundaries (which generally correspond to the eastern and western sides of the channel, respectively) were located at piezometers 1 and 5, respectively, and were specified-head and specified-temperature boundaries. The geometry of the bottom boundary was based approximately on the location of the depths of all piezometers. The hydraulic-head and temperature values from the deepest observation points were used as the specified-head and specified-temperature boundary values. The upper model boundary corresponds to the surveyed land surface and stream channel. The land surface next to the channel on both banks was a specified-temperature, no-fluid flow boundary allowing exchange of heat with the land surface through the unsaturated zone. The Teton Village cross-section model had 100 columns and 100 rows, with the column width equal to $0.1 \mathrm{~m}$ and the row height equal to $0.02 \mathrm{~m}$. The Resor's Bridge cross-section model had 80 columns and 76 rows, with the column width equal to $0.2 \mathrm{~m}$ and the row height equal to $0.02 \mathrm{~m}$. The Wilson cross-section model had 117 columns and 113 rows, with the column width equal to $0.2 \mathrm{~m}$ and the row height equal to $0.02 \mathrm{~m}$.

The model was designed to simulate transport of water and heat between the stream and streambed. Unsaturated flow processes above the water table, including recharge from precipitation through the soil, were not simulated. The stream boundary was a specified-head and specified-temperature boundary based on stream stage and temperature. The stream channel width had two static values: one for high flows and one for base flows. 
Table 1. Name and location of continuous temperature instruments at the Teton Village, Resor's Bridge, and Wilson cross sections on Fish Creek.

[Thermistor name is a reference to the target depth below land surface that the thermistor was to be placed, approximately 75 and 150 centimeters below land surface for the upper and lower thermistors in the streambank piezometers (numbers 1,2, 4, and 5), and approximately 30 and 90 centimeters below land surface for the upper and lower thermistors in the midchannel piezometers (number 3), respectively. Piezometer TV3a was the only piezometer with three thermistors after the piezometer had 0.3 meter of casing added to the depth in October 2005. NAD 1983, North American Datum of 1983; --, not applicable]

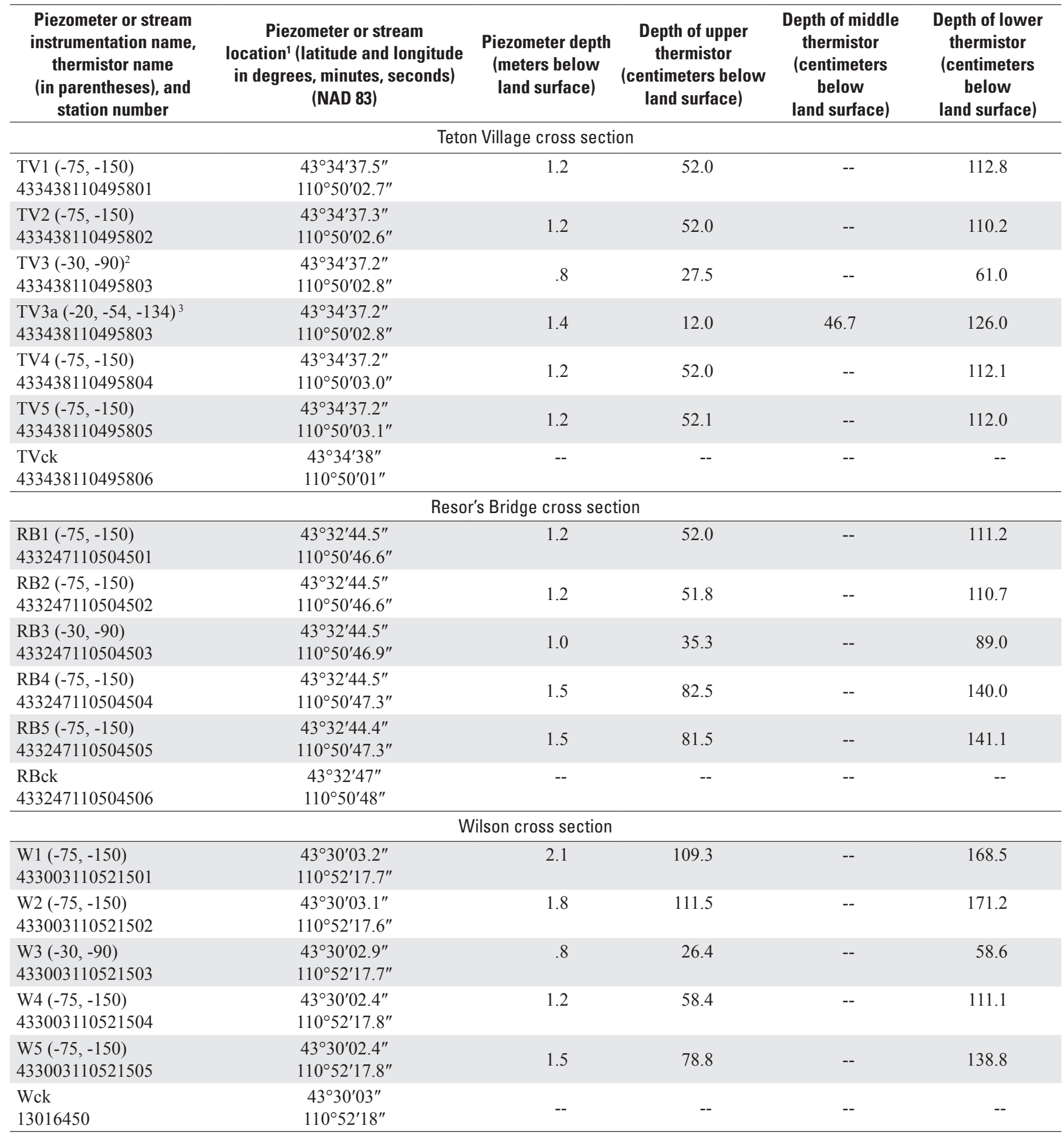

${ }^{1}$ All latitude and longitude measurements were obtained with a handheld global positioning system (GPS) instrument.

${ }^{2}$ Setup in operation from October 2004 to October 2005.

${ }^{3}$ Setup in operation from October 2005 to October 2006. 


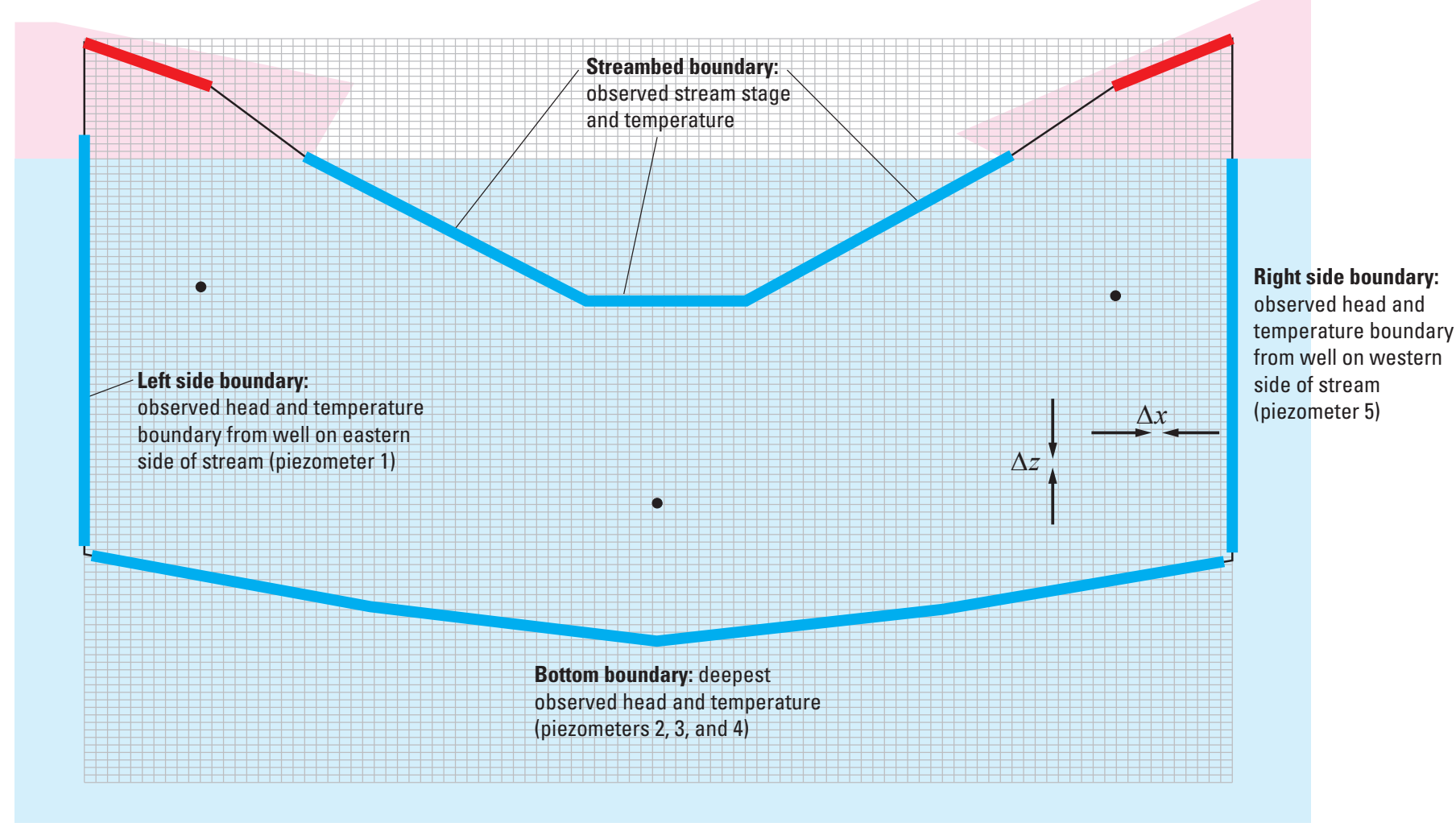

\section{EXPLANATION}

Near-streambed aquifer hydraulic properties

Soil hydraulic properties

Specified-head and specified-temperature boundary

Specified-temperature boundary

No specified head or temperature at boundary

$\Delta x \quad$ Horizontal discretization

$\Delta z \quad$ Vertical discretization

- Observation point-corresponds to location in piezometer where temperature is measured

The vertical distances (z) in all three Fish Creek cross sections are exaggerated compared to the horizontal (x) distances.

Figure 12. Generalized two-dimensional VS2DH model of water and heat transport through the near-stream aquifer along Fish Creek. 
Daily mean values of hydraulic head and temperature were used to specify boundary-condition values along each model boundary for each recharge period. All stream stage, center piezometer (piezometer 3) groundwater-level, and temperature data were collected hourly throughout the study. These data were averaged for each 24 -hour period to determine daily means.

Groundwater levels in the piezometers on the streambanks (piezometers 1, 2, 4, and 5) were not measured continuously, but were hand measured at selected intervals. In order to have a daily mean hydraulic head necessary for model input at these four piezometer locations, a relation was developed between the streambank piezometers (piezometers 1, 2, 4, and 5 ) and the corresponding center piezometer (piezometer 3 ) for each cross section. This relation was developed by determining the water-level difference between piezometers 1, 2, 4, or 5 , and piezometer 3 when levels were hand measured. The change in water level between measurements was then interpolated to estimate a daily difference between each of piezometers 1,2, 4, and 5 and piezometer 3 . A daily water level for each of piezometers $1,2,4$, and 5 was then calculated by using the known daily water level for piezometer 3 and the estimated difference between the piezometer of interest and piezometer 3 .

At each specified-head and specified-temperature boundary, a set of data with the daily mean groundwater level and daily mean temperature was used as the input for each recharge period. At specified-temperature boundaries with no fluid flow, only one datum (temperature) per recharge period was input.

For Fish Creek, the model boundary that was most likely to change location during the study period was the streambed boundary, either because of erosion and deposition of sediments during varying flow regimes or because of changes in channel width related to normal variations in flow volume. The streambed cross-sectional altitude was surveyed in December 2004 and again in August 2005. Survey data indicated that the altitude changed minimally between the two surveys. Therefore, it is assumed that for the period of study, the channel geometry was stable. Changes in channel width due to flow volume were estimated for each site, and changes were made to the model boundaries accordingly.

The hydraulic heads and temperatures of all boundaries vary continuously in a spatial sense. However, due to the limited spatial extent of the data collected, the physical locations of most boundaries were held static during the simulations. The hydraulic heads and temperatures at each boundary were varied in a stepwise manner.

Three model observation points were selected to correspond to the locations of the upper thermistors in piezometers 2, 3, and 4 at each cross section (fig. 12). During the model calibration process, the simulated temperatures for these observation points were compared to the measured temperatures at the corresponding points.

\section{Hydraulic and Thermal Properties and Model Calibration}

Estimates of hydraulic and thermal properties, such as porosity, heat capacity of water, thermal conductivity of the saturated sediment, dispersivity, and horizontal and vertical hydraulic conductivity of sediments, were needed for input into VS2DH and were based on published values (table 2; Freeze and Cherry, 1979; Niswonger and Prudic, 2003). These properties were assigned constant values throughout the soil or streambed on the basis of published values for similar textural materials. Simulated temperature distributions are most sensitive to changes in flow rates and therefore are most sensitive to changes in hydraulic conductivity (Niswonger and Prudic, 2003). Changes in the saturated hydraulic conductivity in the horizontal direction, perpendicular to streamflow, affect the simulated rate of lateral inflow of groundwater to the stream and the simulated temperatures at the observation points below the streambanks (piezometers 2 and 4). Changes in vertical hydraulic conductivity control the simulated amount of vertical flow into the streambed and generally affect the simulated temperatures at the center observation point (piezometer 3 ). This agrees with the general spatial streambed flow pattern, although as described in a following section, Fish Creek shows complex, reach-specific spatial flow patterns.

The saturated hydraulic conductivity of the soil was set to a very low value of $1 \times 10^{-8}$ meters per second $(\mathrm{m} / \mathrm{s})$, which was at least two orders of magnitude smaller than the hydraulic conductivity of the nearby aquifer materials. This simplified the numerical simulation by limiting the movement of groundwater from the saturated soil area into the unsaturated soil area as the water table fluctuated.

The simulated temperatures for all observation points from each simulation were plotted and compared to the corresponding temperatures recorded by thermistors (measured temperatures). On the basis of the closeness of fit between the simulated and measured temperatures, the hydraulic properties were adjusted and the model was rerun. This technique was a trial-and-error stepwise approach to adjusting the horizontal and vertical hydraulic conductivities to obtain a set of simulated temperatures at the observation points that best matched the measured temperatures. Because of the estimation of the daily mean hydraulic head in piezometers $1,2,4$, and 5 , the uncertainty in boundary conditions, and the assumption of uniform properties, an exact match was not expected. Generally, excellent matches between simulated and measured temperatures were obtained below the center of the stream channel where flow is predominantly one-dimensional and vertical. However, the temperatures at piezometers 2 and 4 (bank piezometers, $1 \mathrm{~m}$ from the stream edge) were influenced by the combined effects of lateral and vertical flow, and the heat conduction from the land surface, making close matches difficult to obtain. Once the vertical and horizontal saturated hydraulic conductivities were determined that best reproduced 
the general spatial and temporal trends of measured temperatures at the cross section (as described in more detail in the following section), the VS2DH model was used to estimate the flux of water across selected model boundaries.

\section{Design and Calibration of Cross-Sectional Models}

VS2DH was used to develop a model for each of the three cross sections on the basis of field surveys of channel geometry and of water-level and temperature data. The inverse-modeling technique described previously was used to determine the horizontal and vertical hydraulic conductivities at each cross section. Although the general modeling approaches for the three cross sections were similar, several factors, such as period of time modeled, changes in channel width, and design of specific model boundaries, were unique for each cross section. Table 2 summarizes the parameters used in the final calibrated models.

\section{Teton Village Cross Section}

The Teton Village cross section is in an intermittent reach of Fish Creek recently reworked from a straight-line drain channel cut through a field to an engineered meandering stream. A schematic of the 2-D model with boundary conditions is shown in figure 13. During stabilization of the channel in 2004, a layer (approximately $0.5-\mathrm{m}$ thick) of silty sand was deposited on the left side of the channel as part of a point bar development. Figure 13 shows this thin, lower permeability layer on the left side of the streambed in the model. The layer was assigned a saturated hydraulic conductivity of $1 \times 10^{-5} \mathrm{~m} / \mathrm{s}$ (Freeze and Cherry, 1979).
The channel width at the Teton Village cross section changed during the study period when flow was in the channel. During the spring (April 15 to May 7, 2006) and fall (September 15 to October 14, 2006) periods when flows were low, an estimated average channel width of $5.1 \mathrm{~m}$ was used in the model. During the summer (May 8 to September 14, 2006) period when the flows were high, an estimated average channel width of $7.1 \mathrm{~m}$ was used (fig. 13). The soil boundary was increased for the spring and fall periods when more soil was exposed as a result of the smaller channel width.

Two models were initially developed: one for 2005 and one for 2006. Simulations for 2005 did not produce stable results. The likely reason for this is the large upward hydraulic gradient from the bottom boundary to the streambed, and the short vertical distance between the thermistors in the center piezometer (TV3), which typically recorded the same temperature. Because of this data limitation, the simulation results for 2005 are not discussed in this report.

Stage data and water-level data were collected continuously in TVck and piezometer TV3a from April 15 to October 14, 2006. Water levels were measured in piezometers 1, 2, 4, and 5 only twice during 2006 (May 12 and October 14). The first water-level measurement corresponded to a period when water levels were rising quickly, and the second water-level measurement corresponded to a period when water levels in the aquifer were decreasing. The water levels during these times reflected a disconnection between the aquifer and the piezometer. Upon extraction of the piezometers in October 2008, it was seen that the piezometer screens had plugged, and thus the response time to equilibrium between the piezometers and aquifer was likely delayed. Therefore, it was assumed that a better method of estimating daily water levels in piezometers $1,2,4$, and 5 would be to use

Table 2. Summary of hydraulic parameters used in final calibrated VS2DH models for each cross section.

$\left[\mathrm{m} / \mathrm{s}\right.$, meters per second; $\mathrm{m}$, meters; $\mathrm{W} / \mathrm{m}^{\circ} \mathrm{C}$, Watts per meter degrees Celsius; $\mathrm{J} / \mathrm{m}^{3}{ }^{\circ} \mathrm{C}$, Joules per cubic meter degrees Celsius ]

\begin{tabular}{|c|c|c|c|}
\hline Hydraulic parameter & Teton Village & Resor's Bridge & Wilson \\
\hline $\begin{array}{l}\text { Hydraulic conductivity of near-streambed sediments, } \\
\text { horizontal direction }(\mathrm{m} / \mathrm{s})\end{array}$ & $1 \times 10^{-4}$ & $5 \times 10^{-5}$ & $1 \times 10^{-4}$ \\
\hline $\begin{array}{l}\text { Hydraulic conductivity of near-streambed sediments, } \\
\text { vertical direction }(\mathrm{m} / \mathrm{s})\end{array}$ & $1 \times 10^{-4}$ & $1 \times 10^{-5}$ & $5 \times 10^{-6}$ \\
\hline Dispersivity (m) & ${ }^{2} .01$ & ${ }^{2} .01$ & ${ }^{2} .01$ \\
\hline Thermal conductivity of saturated sediments $\left(\mathrm{W} / \mathrm{m}^{\circ} \mathrm{C}\right)$ & ${ }^{2} 1.8$ & ${ }^{2} 1.8$ & ${ }^{2} 1.8$ \\
\hline Heat capacity of water at $20^{\circ} \mathrm{C}\left(\mathrm{J} / \mathrm{m}^{3}{ }^{\circ} \mathrm{C}\right)$ & $24.2 \times 10^{6}$ & ${ }^{2} 4.2 \times 10^{6}$ & ${ }^{2} 4.2 \times 10^{6}$ \\
\hline
\end{tabular}

${ }^{1}$ Based on Freeze and Cherry, 1979.

${ }^{2}$ Based on Niswonger and Prudic, 2003. 
the hydraulic-head difference between these piezometers and piezometer 3 during a more steady-state period. The steadystate period chosen was August 25, 2005, when piezometers 1, 2,4 , and 5 had water levels that were $0.3 \mathrm{~m}$ greater than water levels in piezometer 3 .

These initial simulations resulted in simulated temperatures that closely approximated the measured data at the observation points, with the exception of thermistor TV4-75. Evaluation of thermographs for the Teton Village cross section (figure 26 in the "Supplemental Information" section) showed that there was more direct upward flow from thermistor TV4-150 to thermistor TV4-75 than horizontal flow from thermistor TV5-75 to thermistor TV4-75 because the temperatures between the latter thermistors did not correspond with each other. This increased vertical flow could be due to two potential causes: (1) the reworked channel potentially contains heterogeneous material and (2) the flow in the channel may be causing a velocity head on the side of the streambed that may be increasing the hydraulic head in piezometer TV4. Therefore, two different types of changes were made to the model to try to simulate the increased upward flow. The first change was to add a small area with higher hydraulic conductivity to the right bank side of the stream, which would create a preferential upward flow. A simulation could not be completed with this change. The second change was to make the hydraulic head in piezometer TV4 slightly higher $(0.05 \mathrm{~m})$ than the hydraulic head in piezometers TV1, TV2, and TV5. The subsequent simulations produced results that better matched the measured data (fig. 14).

The best match between simulated and measured temperatures occurred when the saturated hydraulic conductivity was set at $1 \times 10^{-4} \mathrm{~m} / \mathrm{s}$ in both the horizontal and vertical directions (fig. 14 and table 2). The lack of anisotropy at this cross section is likely due to the nonnatural, reworked nature of the streambed and may contribute to the small horizontal component of flow compared with the Resor's Bridge and Wilson cross sections. However, the dominant vertical flow component is likely caused by the strong vertical hydraulic gradient.

\section{Resor's Bridge Cross Section}

The middle section of Fish Creek is represented by the Resor's Bridge cross section. This cross section is near the point where streamflow changes from intermittent to perennial.

A 2-D model of the Resor's Bridge cross section was developed for the period June 6, 2005, to October 14, 2006. Figure 15 shows the physical design of the model used to simulate water and heat transport through the cross section. During the winter and spring, streamflow at the cross section decreased such that the stream width was less than in the summer and fall. Two sections of the streambed boundary in the model were modified to become no-flow boundaries for the low-flow period between December 3, 2005, and April 10, 2006, as noted in figure 15.

During the winter, the width of the channel decreased and although water was typically maintained across the bed, flow was minimal. The stream stage across the entire streambed boundary was therefore estimated as the altitude of the miniTROLL. During much of the winter, the groundwater level was lower than the stream stage, and the groundwater and surface water appeared to have minimal hydraulic connection because the changes in the groundwater level were not related to changes in the stream stage. Adjusting the model to transport the heat merely by conduction, without advection, as if the groundwater were hydraulically isolated from the surface water, provided a poor match between the simulated and measured temperatures. This was verified by observing that the transport of heat in the stream (recorded at thermistor RBck) did not transmit through the subsurface during the model simulation, in order to detect the temperature change in the observation thermistors. Therefore, although the volume of water recharging the groundwater was not sufficient to raise the hydraulic head of the groundwater to the level of the streambed, the simulated temperature data showed that there was a hydraulic connection between the surface water and the groundwater. Although the Resor's Bridge cross-sectional model was not set up to evaluate unsaturated flow in the soil area, VS2DH is capable of simulating any unsaturated flow scenarios that might develop below the streambed.

The differences between simulated and measured temperatures at observation point RB4-75 were greatest during the winter months. The most likely cause of these differences was an error in estimating the groundwater level in piezometer RB4. Another possible error was in the estimated width of the streambed when the stream went partially dry in the winter. Observations during the winters of 2004-05 and 2005-06 showed that the stream in the channel near the right bank was always flowing a small amount, but the exact streambed width was not known, as noted previously. An estimated average width was used in the model.

Comparisons between the simulated and measured temperatures at the observation points for different hydraulic conductivities determined that the best match of the temperatures was when saturated horizontal hydraulic conductivity was set at $5 \times 10^{-5} \mathrm{~m} / \mathrm{s}$ and vertical hydraulic conductivity was set at $1 \times 10^{-5} \mathrm{~m} / \mathrm{s}$ (fig. 16). Although there are noted differences between simulated and measured temperatures (in late December to late April, in particular), this set of hydraulic conductivities yielded the best temperature match at the most important times, that is when fluxes were at their highest and the period of time between interpolated hydraulic heads in the piezometers was shortest. More weight was given to data from piezometer RB3's observation point when determining best match because the majority of flow into the model area was from the bottom boundary (represented by piezometer RB3) and because the groundwater level for piezometer RB3 was measured rather than estimated. 
Eastern side

Western side

(Left bank)

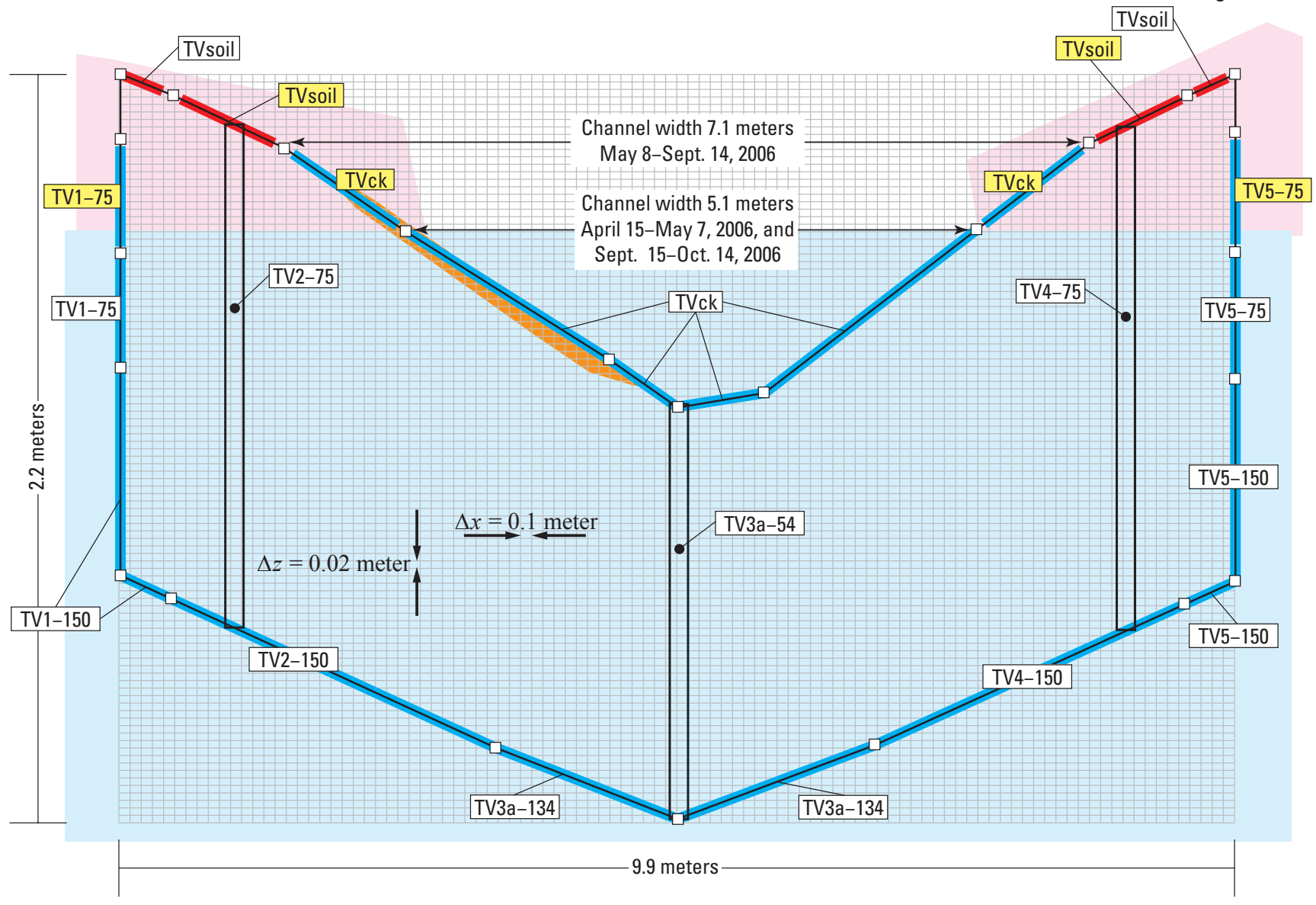

EXPLANATION

Near-streambed sediments hydraulic properties (table 2)

General soil hydraulic properties (table 2)

Silty sand layer hydraulic properties

TV3a-134 Water-level and thermistor data used for boundary input-Boundaries with names in yellow boxes were not a water or heat flux boundary during the spring and late summer (Apr. 15, 2006-May 7, 2006, and Sept. 15, 2006-0ct. 14, 2006) to correspond with the periods when a portion of the streambed was dry and the water table was lower

$\begin{array}{ll} & \begin{array}{l}\text { Specified-head and specified-temperature bou } \\ \text { Specified-temperature boundary }\end{array} \\ & \text { No specified head or temperature at boundary } \\ \square & \text { Approximate piezometer location } \\ \Delta x & \text { Horizontal discretization } \\ \Delta z & \text { Vertical discretization } \\ \bullet & \text { Model observation point } \\ \square & \text { Boundary end point }\end{array}$

Figure 13. Boundary conditions and observation points for the VS2DH model for the Teton Village cross section. 

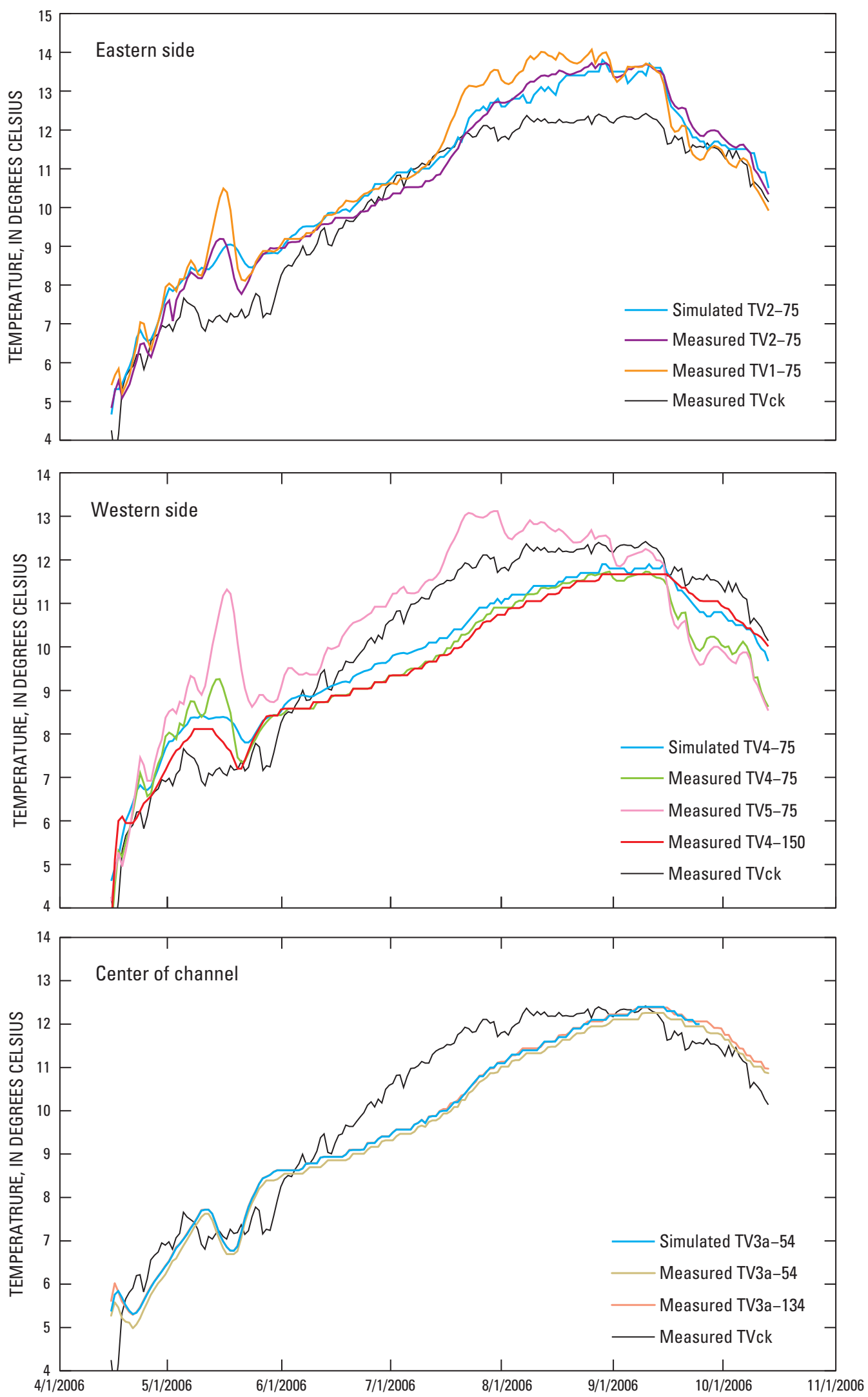

Figure 14. Simulated and measured temperatures for the Teton Village cross section. Horizontal hydraulic conductivity was set at $1 \times 10^{-4}$ meters per second $(\mathrm{m} / \mathrm{s})$, and vertical hydraulic conductivity was set at $1 \times 10^{-4} \mathrm{~m} / \mathrm{s}$. 


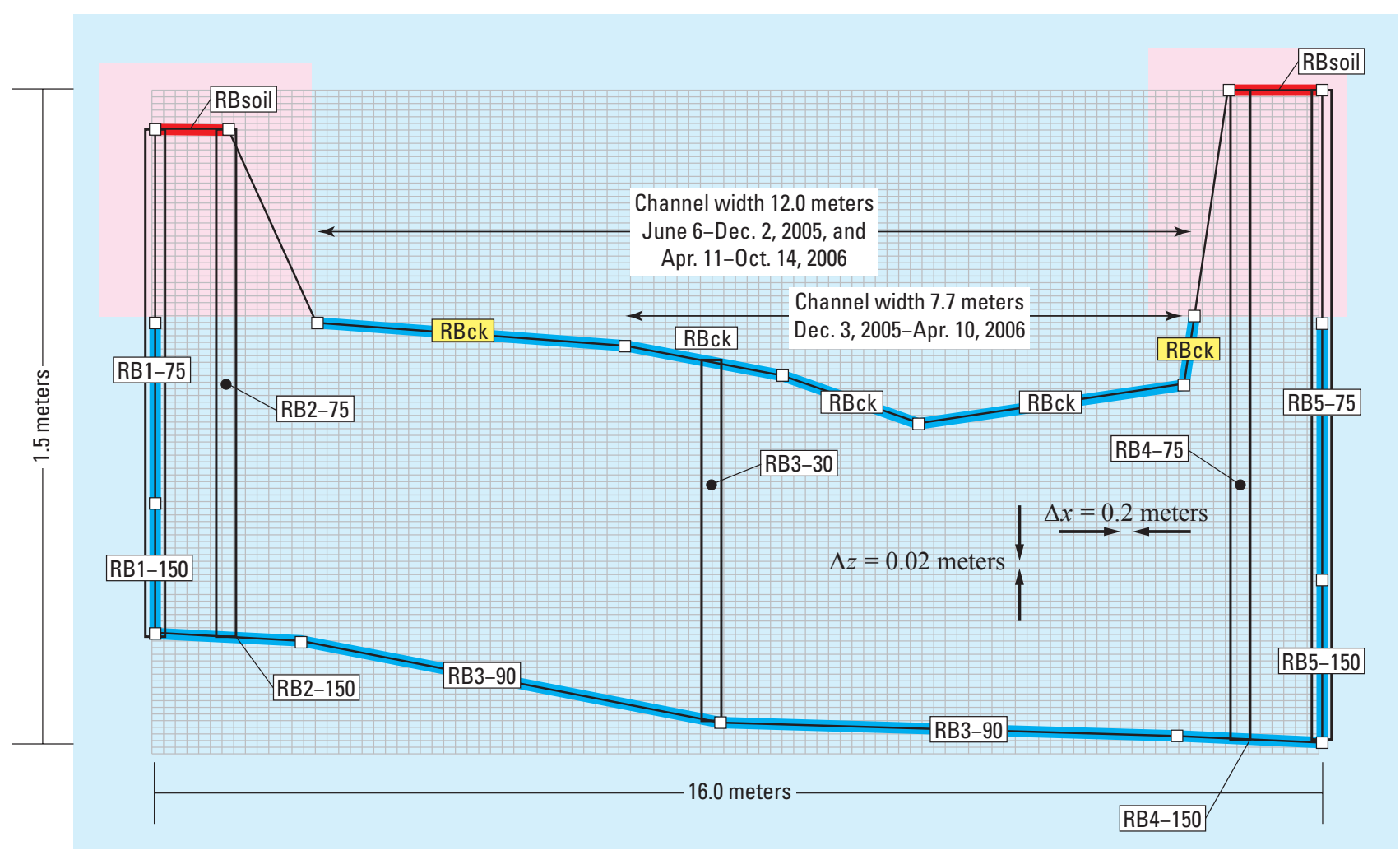

\section{EXPLANATION}

Near-streambed sediments hydraulic properties (table 2)

Soil hydraulic properties (table 2)

RB3-90 Water-level and thermistor data used for boundary input-Boundaries with names in yellow boxes had no flow during the winter (Dec. 3, 2005-Apr. 10, 2006) to correspond to periods when the streambed was dry

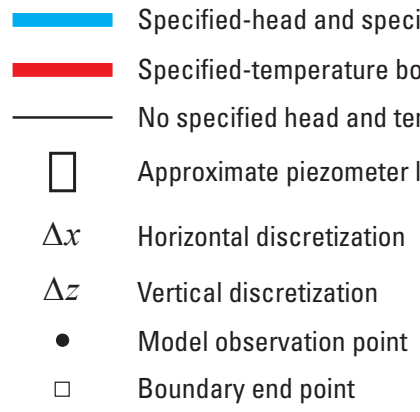

Figure 15. Boundary conditions and observation points for the VS2DH model for the Resor's Bridge cross section. 

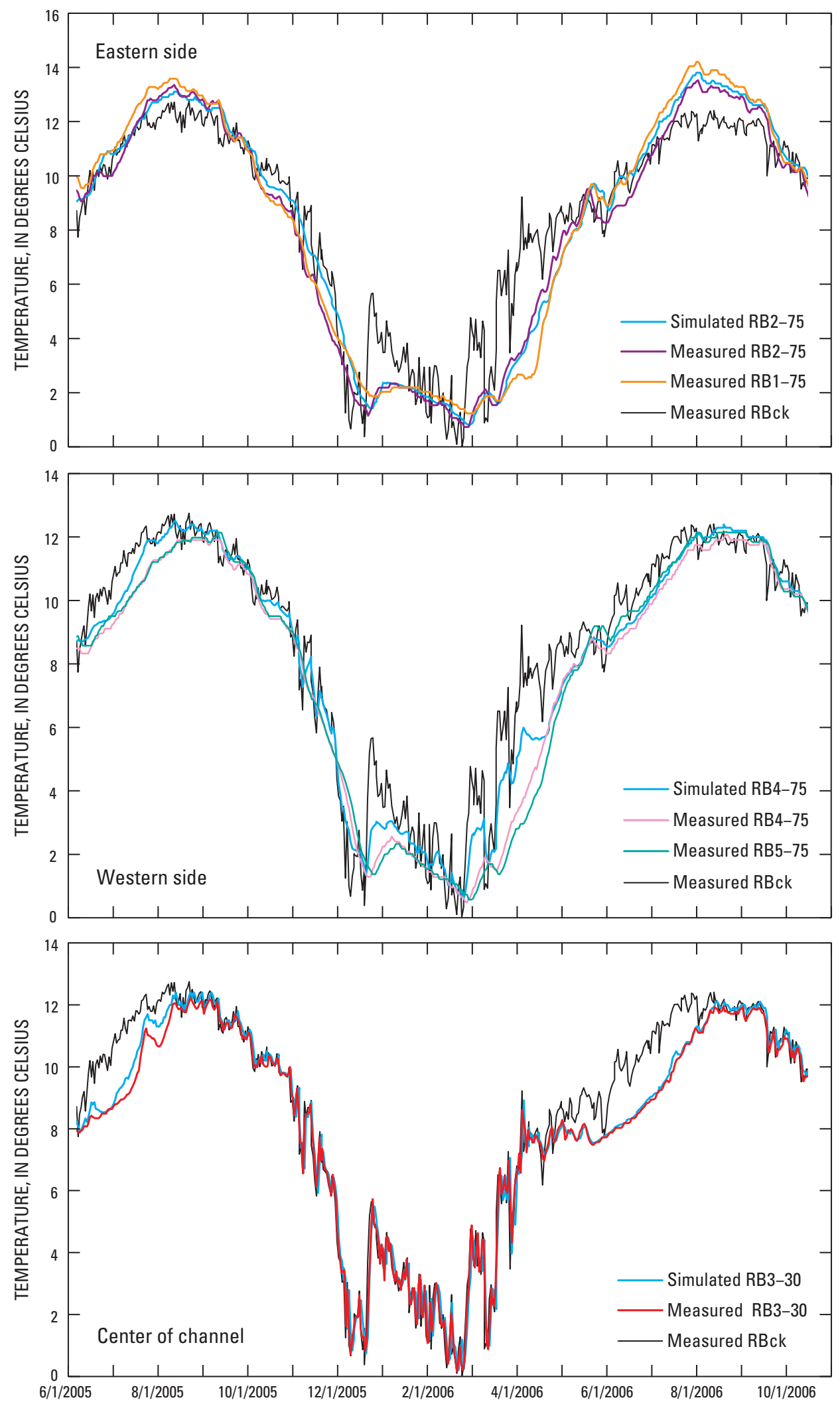

Figure 16. Simulated and measured temperatures for the Resor's Bridge cross section. Horizontal hydraulic conductivity was set at $5 \times 10^{-5}$ meters per second $(\mathrm{m} / \mathrm{s})$, and vertical hydraulic conductivity was set at $1 \times 10^{-5} \mathrm{~m} / \mathrm{s}$. 


\section{Wilson Cross Section}

The farthest downstream site evaluated was the Wilson cross section. This site is on a perennial reach and is near USGS gaging station 13016450. The 2-D model of the Wilson cross section was designed for the period from June 6, 2005, to October 14, 2006. Figure 17 shows the physical design of the model used to simulate heat and water transport through the cross section. During the late fall, winter, and spring, streamflow at the cross section decreased such that the stream width was less than at other times of the year. The model was designed to have two sections of the streambed that convert to no-flow boundaries when the stage was low in the late fall, winter, and spring.

The physical design of the model for the Wilson cross section is consistent with the design of models for the Teton Village and Resor's Bridge cross sections. Because of the increased stream width at Wilson, the width of the simulated area is much greater than the depth (or height) in the model as seen in the model schematic (fig. 17). The large difference between width and depth made it unreasonable to assume that data collected at piezometer W3 would represent the physical characteristics of the subsurface below the entire width of the stream channel. Although the true extent of piezometer W3's zone of influence was not known exactly, it was assumed that the data from the piezometer represented conditions within a distance of about $4.5 \mathrm{~m}$ on each side of the piezometer. This value is slightly smaller than the 6-m distance for the center piezometer at Resor's Bridge, but due to the uncertainty associated with the Wilson cross section, the $4.5-\mathrm{m}$ distance was considered a reasonable assumption. On the basis of the piezometer distribution, it was not possible to specify boundary conditions across the entire perimeter of the cross section. Therefore, the 2-D model was designed as three onedimensional models running at the same time, with a left-bank section, a center-channel section, and a right-bank section.

Evaluation of simulated thermographs showed that the relation between the bottom boundary (represented by piezometer 3 ) and the streambed was reasonably described by the model on the basis of close matches between simulated and measured temperatures at thermistor W3-30 (fig. 18). Initially, the ability of the model to simulate reasonable temperatures at thermistors W2-75 and W4-75 was not as good. After evaluating several potential causes for the lack of agreement, it was determined that the thermistor recording soil temperature at the Wilson cross section and used for the land-surface boundary condition (Wsoil, fig. 11) showed large temperature fluctuations that influenced the simulated subsurface temperatures. This thermistor was in an exposed location with little vegetation nearby, unlike the surrounding area, and likely did not represent the soil temperature of the general area. Therefore, soil temperature data from the Resor's Bridge cross section were used for the land surface's specified-temperature boundary condition in the Wilson cross-sectional model.

The streambed boundary had two widths to accommodate the change in stream width during the year. The channel width was $17.8 \mathrm{~m}$ from June 6 to October 7, 2005, and May 9 to October 14, 2006, and was $12.6 \mathrm{~m}$ from October 8, 2005, to May 8, 2006, as noted in figure 17 .

Comparison of simulated and measured temperatures (fig. 18) showed the best match was when the saturated hydraulic conductivity was set at $1 \times 10^{-4} \mathrm{~m} / \mathrm{s}$ in the horizontal direction and $5 \times 10^{-6} \mathrm{~m} / \mathrm{s}$ in the vertical direction (table 2). Temperature matches for observation points in piezometers W2 and W4 were not as close as those for other locations, and the difference was likely due to uncertainties with respect to the exact location, temperature, and flow condition of the bottom boundary near the sides of the model. However, matches were considered satisfactory for proceeding with estimating fluxes for the cross section.

\section{Characterization of Interactions between Surface Water and Near- Stream Groundwater}

The interactions between surface water and near-stream groundwater are qualitatively described in this report as the direction and relative magnitude of flow based on measured water levels and temperatures. Interactions are quantitatively described as fluxes between surface water and groundwater based on simulations of flow and heat transport. The simulated fluxes are compared with the streamflow gains and losses determined during the 2004 seepage investigation.

\section{Direction and Magnitude of Flow Based on Measured Stage, Water-Level, and Temperature Data}

Hourly and daily mean stream-stage data, water-level data from piezometer 3 , and temperature data from all piezometers and the stream were examined to determine the direction and relative magnitude of flow between the surface water and the groundwater in the center of the channel at each stream cross section. These data (figures 26-31 in the "Supplemental Information" section) were used in the model calibration process as previously described, but also were qualitative indicators of flow direction and magnitude.

\section{Teton Village Cross Section}

Stream-stage and groundwater-level data collected at the Teton Village cross section showed that during the period when the stream flowed (from middle to late April through early November), the groundwater level was higher than the stream stage, indicating that streamflow was a result of the rise in the groundwater table (fig. 19A). During 2005 and 2006, the flux of water was consistently upward, from groundwater to surface water; differences in hydraulic head between 
Eastern side

(Left bank)

Western side

(Right bank)

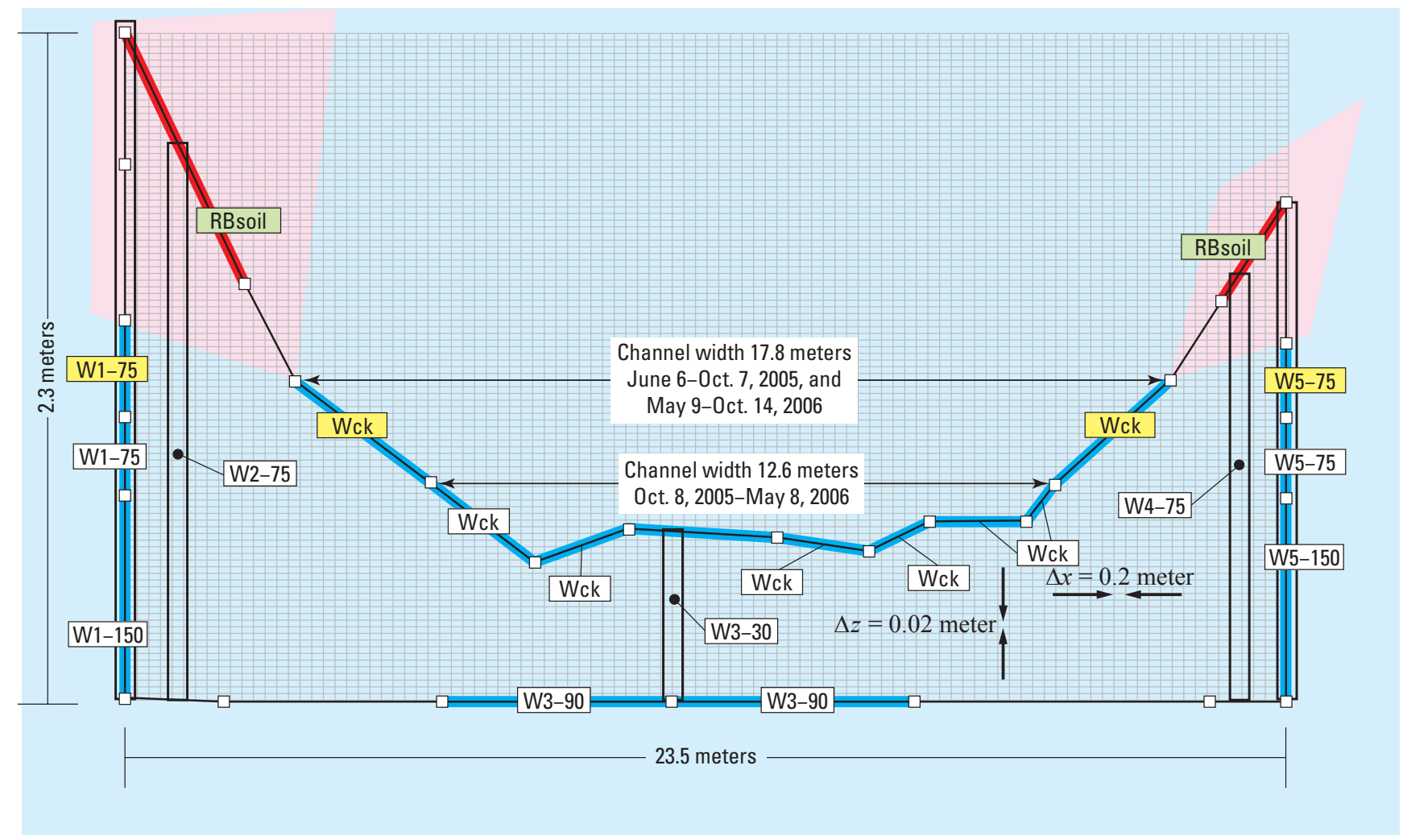

EXPLANATION

Near-streambed sediments hydraulic properties (table 2)

Soil hydraulic properties (table 2)

W3-90 Water-level and thermistor data used for boundary input-Boundaries with names in yellow boxes were changed to a no specified-head and/or specified-temperature boundary during the winter (0ct. 8, 2005-May 8, 2006) to correspond with periods when the groundwater altitude was lower and parts of the streambed were dry

RBsoil Soil temperature from Resor's Bridge cross section See text for explanation.

$\begin{array}{cl} & \begin{array}{l}\text { Specified-head and spec } \\ \text { Specified-temperature bo } \\ \end{array} \quad \begin{array}{l}\text { No specified head or tem } \\ \square\end{array} \quad \begin{array}{l}\text { Approximate piezometer } \\ \Delta x\end{array} \quad \text { Horizontal discretization } \\ \Delta z & \text { Vertical discretization } \\ \bullet & \text { Model observation point } \\ \square & \text { Boundary end point }\end{array}$

Figure 17. Boundary conditions and observation points for the VS2DH model for the Wilson cross section. 

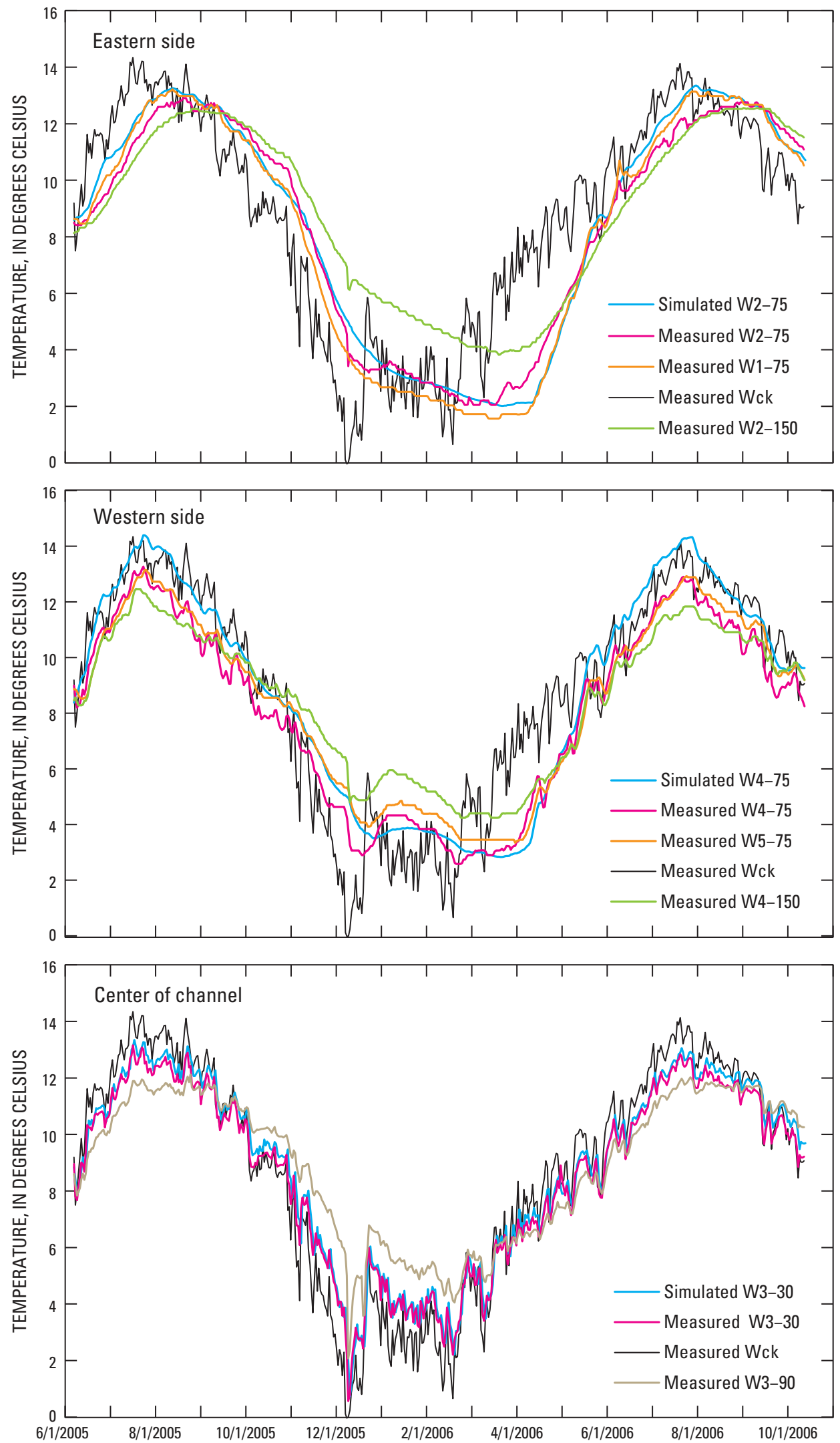

Figure 18. Simulated and measured temperatures for the Wilson cross section. Horizontal hydraulic conductivity was set at $1 \times 10^{-4}$ meters per second $(\mathrm{m} / \mathrm{s})$, and vertical hydraulic conductivity was set at $5 \times 10^{-6} \mathrm{~m} / \mathrm{s}$. 
groundwater at the midchannel piezometer (TV3/TV3a, depths of 0.8 and $1.4 \mathrm{~m}$ ) and surface water ranged from near zero to $0.2 \mathrm{~m}$ (fig. 19B). The influence of this continuous upward flow can be seen in the temperature data from the midchannel piezometer (TV3/TV3a; fig. 19C); data from thermistors in this piezometer do not show the diurnal oscillation of temperatures evident in the data from the stream thermistor (TVck). The thermistor's lowest recordable value is -2 degrees Celsius. During April 2005, the values from thermistor TVck were sometimes greater than 18 degrees Celsius; however, the exact values are not necessary to see the relations between all thermistors. The temperature was relatively uniform with depth in the streambed, indicating the continuous upward advection of heat was stronger than the downward conduction through the water and sediment. Alternatively, during the periods of no streamflow there was a strong temperature gradient in the streambed. A short period of downward flow occurred in early November, before the no-flow period. The abrupt change in flow direction is reflected in the thermal pattern for that period in figure $19 C$.

\section{Resor's Bridge Cross Section}

Stream-stage and groundwater-level data collected at the Resor's Bridge cross section show the stream has a general pattern of gaining water from groundwater during a 2- to 4-month period in the summer and recharging groundwater during the spring and fall (fig. 20A). The sharp rise in groundwater in late April and early May likely was in response to snowmelt on the valley floor, an increase in recharge to the aquifer in the westbank area, higher stages in the Snake River, and infiltration of snowmelt on the western side of the valley. This rise in groundwater level causes flow to increase in Fish Creek. The higher stage in the stream is maintained during the summer by the raised groundwater table, which also is augmented by additional recharge from infiltration of irrigation water applied to the nearby fields. The difference in hydraulic head between the groundwater at the midchannel piezometer (RB3, depth of $1.0 \mathrm{~m}$ ) and surface water during the period of streamflow gain at the Resor's Bridge cross section ranged from 0 to $0.4 \mathrm{~m}$ (fig. 20B). The stream was flowing during all winter site visits, but commonly under ice and at a stage lower than the pressure transducer's sensor due to the channel configuration. The lack of flow at the sensor is reflected as missing data in figure 20. The ice cover indicates a lack of substantial groundwater discharge to the stream in this reach during the winter.

The temperature data support the interpretation of the stage data, in particular the transition from a gaining stream to a losing stream (fig. 20). Temperature data from both thermistors (RB3-30 and RB3-90) in the midchannel piezometer had minimal diurnal fluctuations during approximately mid-May to mid-July of both years when the stream was strongly gaining water from the groundwater. During other times of the year, the temperature data showed diurnal fluctuations when the stream was either gaining less water from the groundwater or recharging the groundwater (fig. 20C). The thermographs for thermistors RBck, RB3-30, and RB3-90 showed that pulses of cold water were able to infiltrate below the streambed during the winter at low flow.

\section{Wilson Cross Section}

At the Wilson cross section, the flux of water in the streambed near the midchannel piezometer (W3) was primarily from groundwater to surface water, as shown by the difference in hydraulic head between the groundwater level in piezometer W3 and the stream stage (Wck; fig. 21B). Two exceptions to this general case occurred during 2005. The first was during the summer when the gradient often was near zero, indicating a minimal amount of flux into or out of the stream. The second was during December when the data show a flux from the stream into the groundwater. Several days of cold air temperatures beginning December 6, 2005, with lows around $-30^{\circ} \mathrm{C}$ and highs around $-15^{\circ} \mathrm{C}$, caused an ice dam immediately downstream from the Wilson cross section, and raised the stream stage $0.6 \mathrm{~m}$ over the course of a day and a half. The dramatic change in stage caused a difference of $0.24 \mathrm{~m}$ between the stage and the groundwater level in piezometer W3 (fig. 21B), which forced colder surface water into the streambed and groundwater. This event can be seen in the stage data and by a cold temperature pulse in piezometers $\mathrm{W} 2, \mathrm{~W} 3, \mathrm{~W} 4$, and W5 for 2 days beginning on December 8, 2005 (fig. 30 in the "Supplemental Information" section).

Stream-stage and groundwater-level data collected during 2006 show that Fish Creek at the Wilson cross section gained water from groundwater throughout the year. The difference in hydraulic head between the groundwater level at piezometer W3 (at a depth of $0.7 \mathrm{~m}$ ) and the stream stage was typically about $0.08 \mathrm{~m}$ and reached a maximum of $0.15 \mathrm{~m}$.

Unlike temperatures at the Teton Village and Resor's Bridge cross sections, temperatures from the midchannel thermistors (W3-30 and W3-90) at the Wilson cross section show diurnal fluctuations (fig. 21C) when the stream is gaining. One explanation is that the downward conduction of heat can penetrate to the depth of the piezometer, even with upward advection of heat, because the upward advection is small due to the small magnitude of the hydraulic head difference between groundwater and surface water at the Wilson cross section. However, this thermal pattern also may be the result of complex three-dimensional flow patterns on a local scale. 

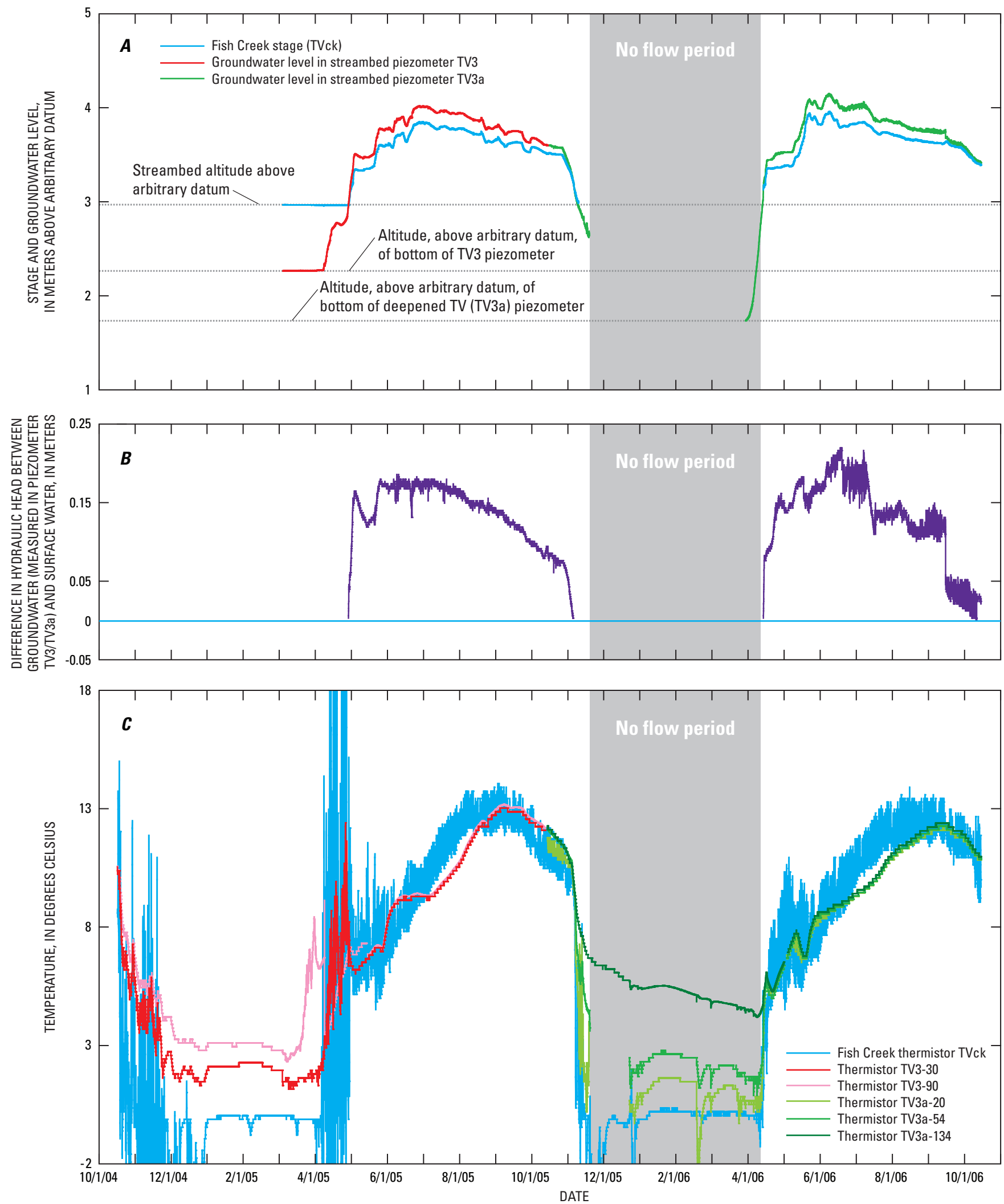

Figure 19. Data collected at the Teton Village cross section. $A$, Hourly stage and groundwater-level measurements. $B$, Difference in hydraulic head between groundwater and surface water, March 5, 2005, to October 14, 2006. $C$, Hourly temperature measurements in surface water and in piezometer TV3/TV3a, October 15, 2004, to October 14, 2006. 

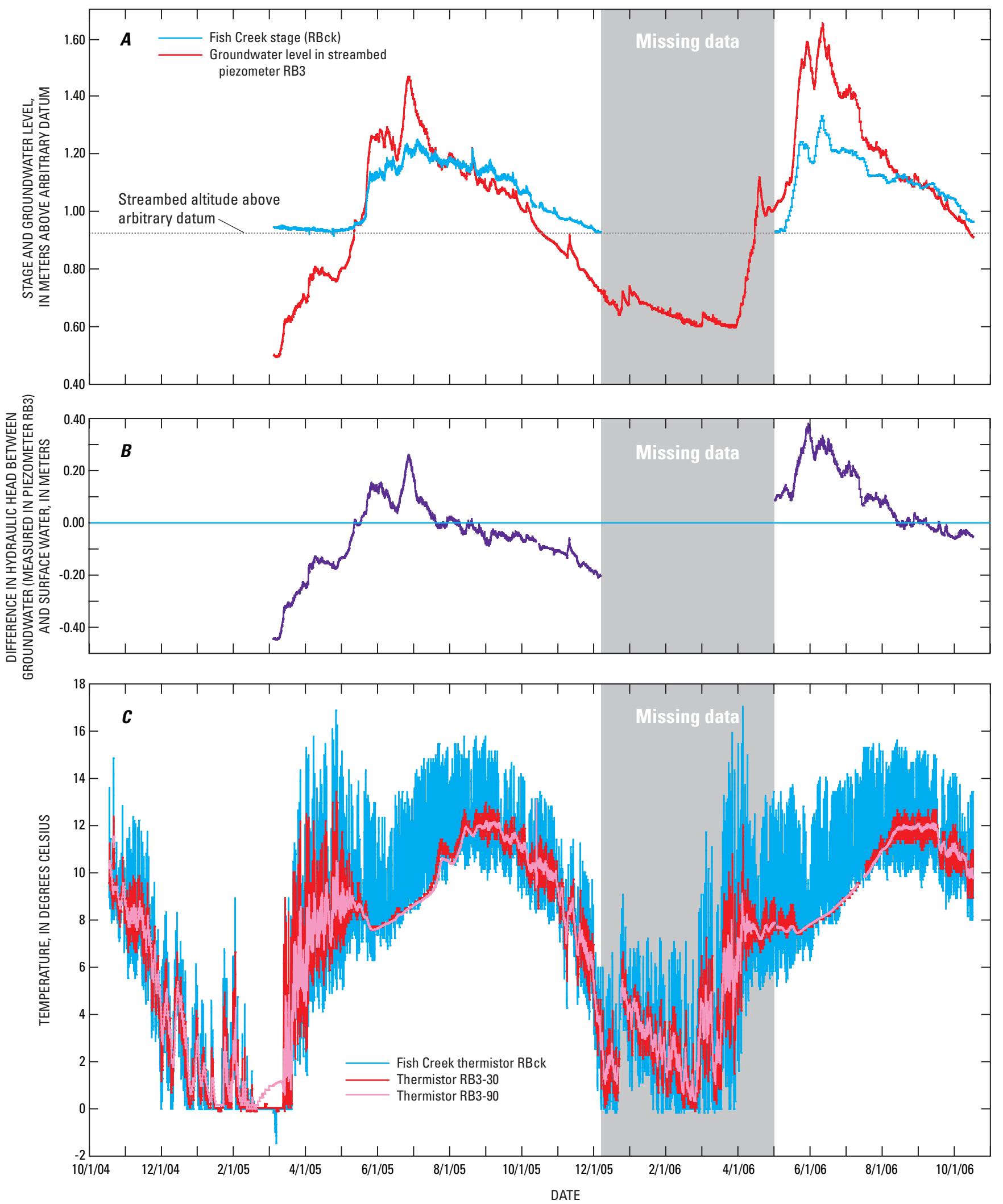

Figure 20. Data collected at the Resor's Bridge cross section. $A$, Hourly stage and groundwater-level measurements. $B$, Difference in hydraulic head between groundwater and surface water March 5, 2005, to October 14, 2006. $C$, Hourly temperature measurements in surface water and in piezometer RB3, 0 ctober 15, 2004, to 0 ctober 14, 2006. Fish Creek stage and groundwater-level data were not collected until March 2005. 

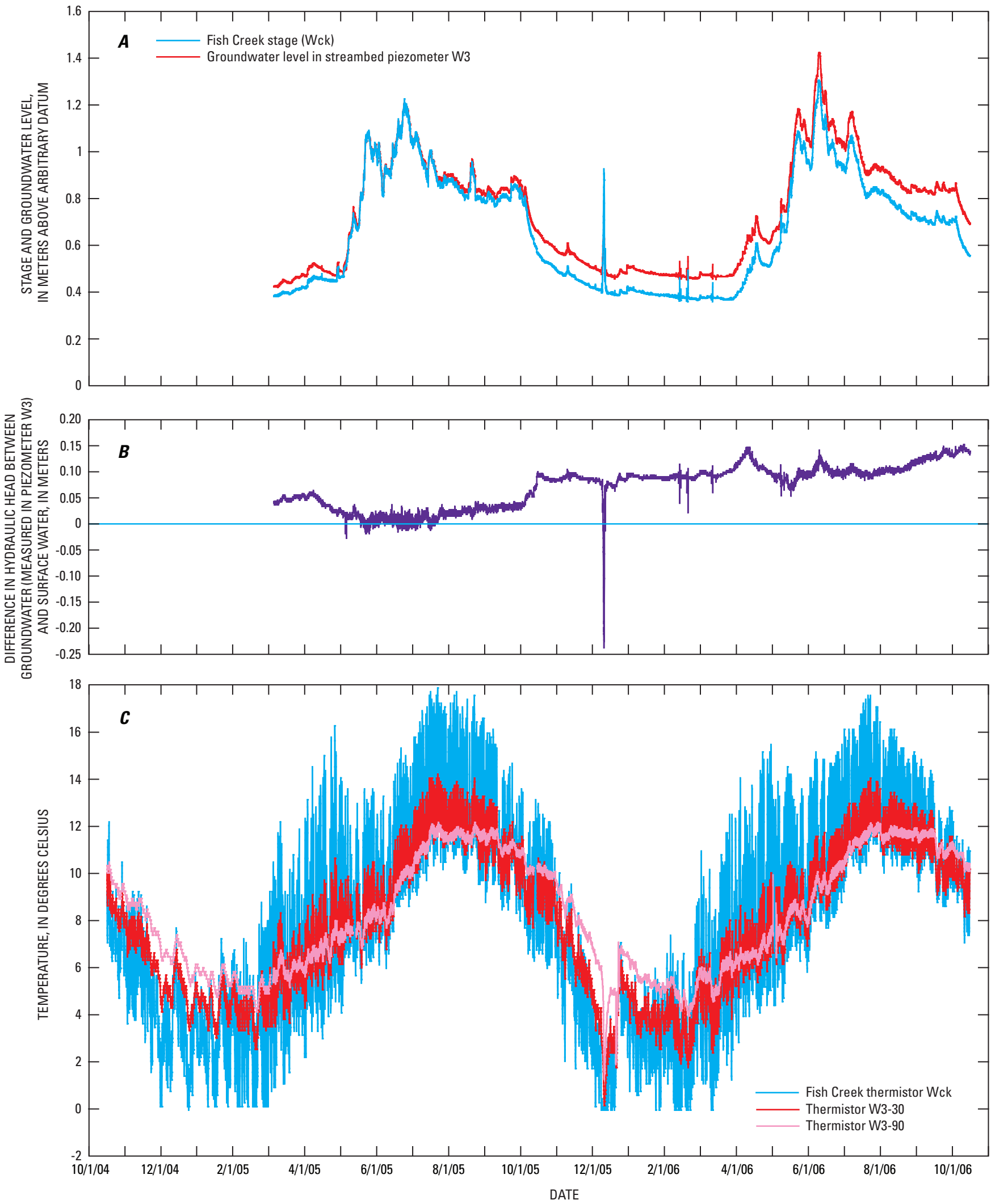

Figure 21. Data collected at the Wilson cross section. $A$, Hourly stage stage and groundwater-level measurements. $B$, difference in hydraulic head between groundwater and surface water, March 5, 2004, to October 14, 2006. $C$, Hourly temperature measurements in surface water and in piezometer W3, October 15, 2004, to October 14, 2006. 


\section{Fluxes Based on Simulations of Flow and Heat Transport}

Groundwater and surface-water fluxes across the stream/ streambed interface can be estimated by using the simulation results from the calibrated flow model at each cross section. Flux values were calculated as flow across the model boundary in cubic meters per day $\left(\mathrm{m}^{3} / \mathrm{d}\right)$. The flux across the boundary is for the total length of the boundary, which varies among the boundaries. The flux per unit area (calculated by dividing the total flux across a boundary by the boundary length) is not given in this report but may be a useful value for the reader to calculate to describe the fluxes in a more normalized format.

The monthly mean flux across the stream/streambed interface was calculated by averaging all daily flux values for each day of a given month (table 3 ). The cumulative monthly flux in cubic meters per month $\left(\mathrm{m}^{3} /\right.$ month) was calculated by summing each daily flux value in a given month across the entire streambed boundary. Positive flux values indicate flow from near-stream groundwater to the stream, whereas negative flux values indicate flow from the stream to groundwater. Also included in table 3 is the monthly mean streamflow at the Fish Creek at Wilson gaging station (U.S. Geological Survey, 2008). Combining the results of the modeling effort with results from past studies of the area (Nelson Engineering, 1992; Wheeler and Eddy-Miller, 2005; Wyoming State Engineer's Office, 2005) can help to expand the overall understanding of interactions between surface water and groundwater in the area near Fish Creek.

\section{Teton Village Cross Section}

Water fluxes at the Teton Village cross section were estimated across four model boundaries: the streambed boundary and three locations along the bottom boundary (fig. 22). During model development, fluxes also were estimated along the side boundaries of the model and it was determined that the input to the system across these boundaries was negligible. Therefore, the bottom boundary of the VS2DH model was subdivided to represent the left bottom (eastern), center bottom, and right bottom (western) sides of the stream (fig. 22B). Flux estimates (fig. 22A) for the streambed boundary are shown as positive when groundwater is moving past the streambed boundary into the stream, and negative when the flux of water is moving past the streambed boundary from the stream to groundwater. Flux estimates for the bottom boundaries are positive when the water flux is into groundwater and negative when the flux past the boundary is into the stream. Temperature distributions within the model domain and magnitude and direction of water flow for three selected dates are illustrated in figure $22 C$.

Overall, the groundwater flux across the streambed is primarily a result of upward flow into the stream channel rather than horizontal flow into the sides of the channel. Estimated daily flux rates (averaged for each month) ranged from
1.1 to $6.6 \mathrm{~m}^{3} / \mathrm{d}$ (table 3 ) into Fish Creek at the Teton Village cross section. Whenever the stream was flowing, there was a gradient from groundwater (high) to surface water (low)even when the water table was declining in the fall. The lack of anisotropy in the streambed sediment likely accounts for some of the predominance of the vertical flux.

In general, the water flux across the streambed had the same general direction and relative magnitude, with a slight lag, as the stages in the stream and the water levels in piezometer TV3 throughout the year. Fluxes from groundwater to Fish Creek ranged from 16 to $199 \mathrm{~m}^{3} /$ month. The quick increase in flow during spring is likely due to a rise in the water table caused by groundwater recharge from a combination of valley snowmelt, irrigation application to nearby fields, an increase in stage in the nearby Snake River, and deep groundwater flow from snowmelt in the mountain range to the west. The slow decrease in stage and groundwater levels throughout the year is likely due to the trailing off of the snowmelt pulse through the deeper groundwater and a slow decrease in the stage of the Snake River (fig. 23). Comparisons of fluxes to precipitation showed little correlation, indicating that groundwater inflow is a more prominent component of streamflow.

Figure 22 ( $A$ and $C$ ) shows that the flux across the rightbottom (western) boundary accounts for more of the flow across the streambed than flux across the other two bottom boundaries. The fluxes across the left-bottom (eastern) and center-bottom boundaries were relatively equal throughout the spring and summer, and reflected an overall slow increase of discharge into the stream. The increase in stream stage and groundwater level from April to June resulted from the increased stage of the Snake River and subsequent recharge (Wyoming State Engineer's Office, 2005), and recharge from the infiltration of irrigation water in nearby ditches and applied to fields. The flux across the right-bottom boundary (western) is more likely due to a deeper pulse of water from snowmelt on the nearby mountain flanks. In early to mid-September, the fluxes across all boundaries quickly decreased, likely because of a decrease in irrigation water applied to nearby fields, which likely maintains the increased water table in the aquifer, and to a drop in the stage of Fish Creek. After the drop in stage, water was lost to the aquifer across the centerbottom boundary (shown as a positive flux in figure $22 \mathrm{~A}$ ), and the water flux from groundwater to surface water across the streambed boundary was maintained in part by flux across the eastern and western parts of the bottom boundary. Additionally, this flux scenario may indicate longitudinal flow in the streambed parallel to the direction of streamflow.

Qualitatively, data show that temperatures on the eastern side, even at depth, do not drop as low and are not as steady as temperatures on the western side and in the center of the channel (fig. 26 in the "Supplemental Information" section). This larger separation of temperature on the eastern side compared to the western side also indicates a decrease in advection on the eastern side, which likely corresponds with the silt/sand point bar on that side of the channel. (Heat transport in systems that is primarily by advection results in 
Table 3. Summary of estimated flux from groundwater to surface water across the streambed boundary in models of Fish Creek cross sections.

$\left[\mathrm{m}^{3} / \mathrm{d}\right.$, cubic meter per day; $\mathrm{m}^{3} /$ month, cubic meter per month; $\mathrm{m}^{3} / \mathrm{s}$, cubic meter per second; NM, not modeled; negative numbers indicate flow is from surface water to groundwater]

\begin{tabular}{|c|c|c|c|c|c|c|c|}
\hline Month & $\begin{array}{c}\text { Streamflow', } \\
\text { Fish Creek at Wilson } \\
\text { (station 13016450) } \\
\left(\mathrm{m}^{3} / \mathrm{s}\right)\end{array}$ & \multicolumn{3}{|c|}{ Monthly mean flux (m³/d) } & \multicolumn{3}{|c|}{ Cumulative monthly flux (m³/month) } \\
\hline${ }^{2}$ June 2005 & 15.7 & NM & 2.9 & 0.1 & NM & 86 & 3 \\
\hline July 2005 & 12.7 & NM & 1.1 & .2 & NM & 36 & 6 \\
\hline September 2005 & 7.9 & NM & -1.6 & .4 & $\mathrm{NM}$ & -48 & 11 \\
\hline October 2005 & 3.4 & NM & -2.5 & .5 & NM & -79 & 16 \\
\hline November 2005 & 1.6 & Dry & -3.8 & .5 & Dry & -114 & 16 \\
\hline December 2005 & 1.1 & Dry & -1.9 & .3 & Dry & -57 & 9 \\
\hline March 2006 & 1.1 & Dry & -2.5 & .4 & Dry & -76 & 13 \\
\hline April 2006 & 2.7 & 4.4 & .6 & .6 & 66 & 19 & 18 \\
\hline May 2006 & 11.1 & 5.4 & 5.1 & .4 & 168 & 159 & 13 \\
\hline June 2006 & 18.8 & 6.6 & 7.4 & .6 & 199 & 222 & 18 \\
\hline July 2006 & 12.5 & 5.6 & 3.8 & .7 & 173 & 119 & 21 \\
\hline August 2006 & 7.8 & 4.9 & .7 & .8 & 152 & 21 & 26 \\
\hline September 2006 & 6.3 & 3.0 & -.7 & 1.1 & 89 & -21 & 33 \\
\hline
\end{tabular}

${ }^{1}$ U.S. Geological Survey, 2008.

${ }^{2}$ Calculation based on 24 days of simulated fluxes in June 2005 .

${ }^{3}$ Calculation based on simulated fluxes for all days (14) where water was in the creek during October 2006.

${ }^{4}$ Calculation based on 14 days of simulated fluxes in October 2006.

smaller differences in the temperature between two points in the subsurface (Jim Constantz, U.S. Geological Survey, oral commun., 2008.)) Additionally, groundwater in piezometers on the eastern side of the stream tended to have higher temperatures than groundwater in piezometers on the western side of the stream, possibly due to a shallow influx of recently recharged groundwater (that is, from irrigation of nearby fields or Snake River recharge) or the slower moving groundwater from the eastern side being affected by the downward flux of heat from the sun warming the soil in the summer. The lower and less dynamic temperatures on the western side of the stream are more indicative of a deeper, steady source of water, such as infiltrated snowmelt.
The estimated flux from groundwater into the stream along the seepage investigation reach near Teton Village was calculated for August 2006 by using the simulated flux values for comparison with the seepage investigation estimate of the stream gain over that reach in August 2004 (Wheeler and Eddy-Miller, 2005). The daily flux of water for August 2006 was calculated by multiplying mean monthly flux per unit area by an estimated average stream width in the reach and by an estimated length of the reach. The average stream width $(3.5 \mathrm{~m})$ was estimated by adding the stream width at the upstream end of the reach to the downstream end of the reach and dividing the sum by two. The stream length was estimated at $1,525 \mathrm{~m}$ by using an interactive geographic information 


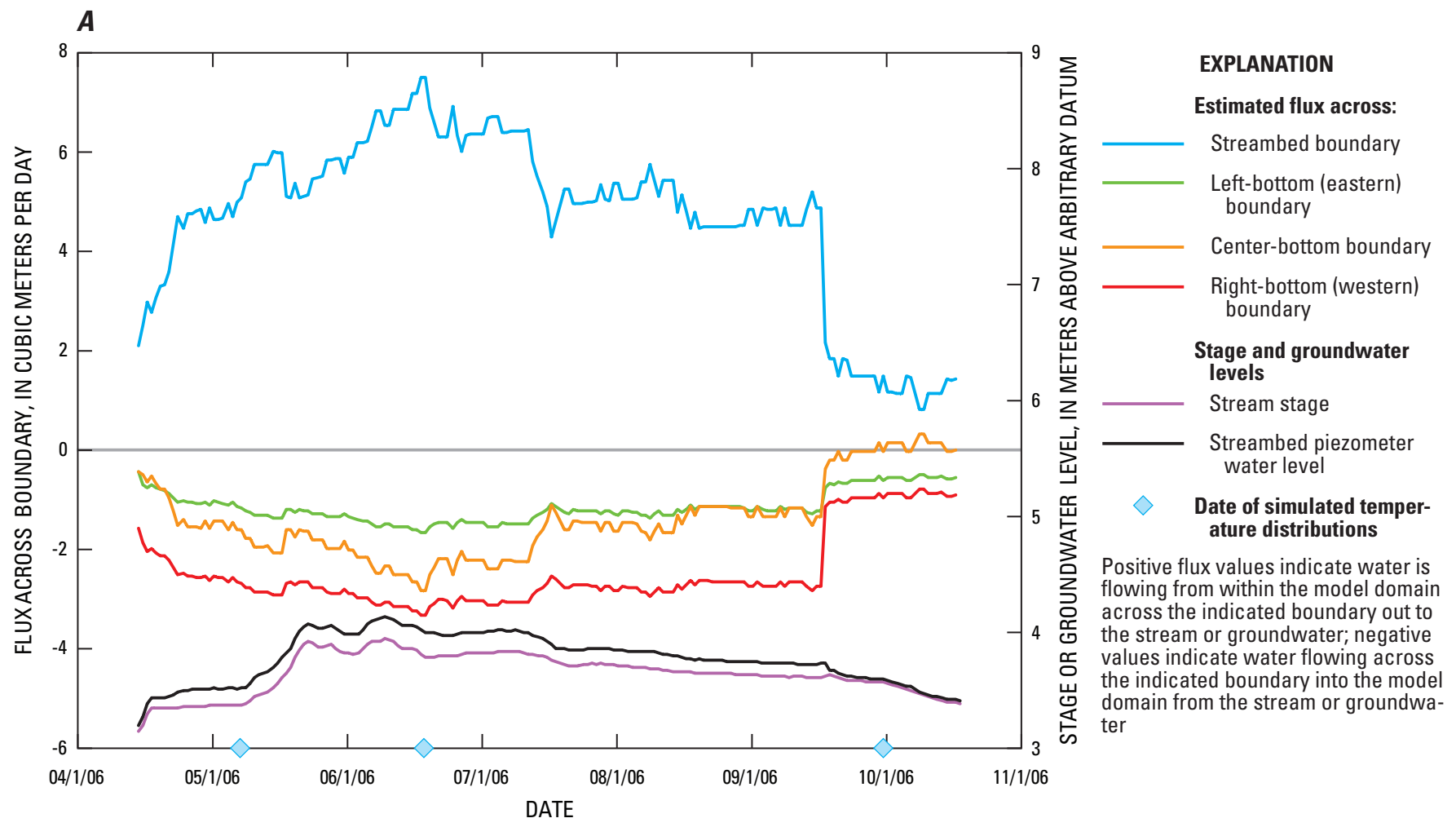

\section{B}
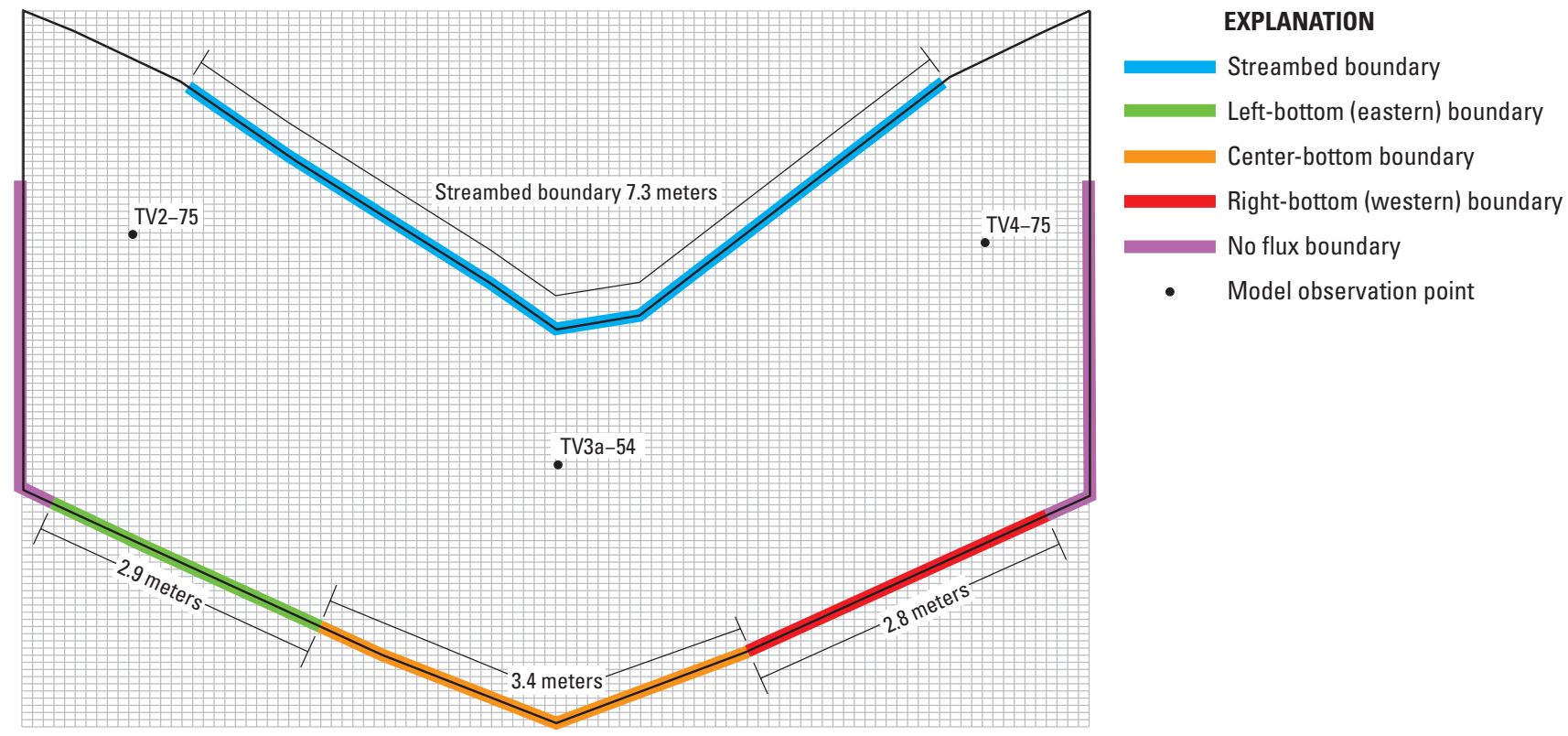

- Model observation point

Figure 22. Selected flux information for the Teton Village cross section. $A$, Daily flux across streambed, left-bottom, center-bottom, and right-bottom boundaries; stage of Fish Creek; and water level in the streambed piezometer (TV3a) from April 15 to 0ctober 14, 2006. $B$, Location and length of flux boundaries in model for which output is shown in $A$. $C$, Simulated temperature distributions inside the model domain on three selected dates (arrows indicate direction and relative magnitude of water flux). 


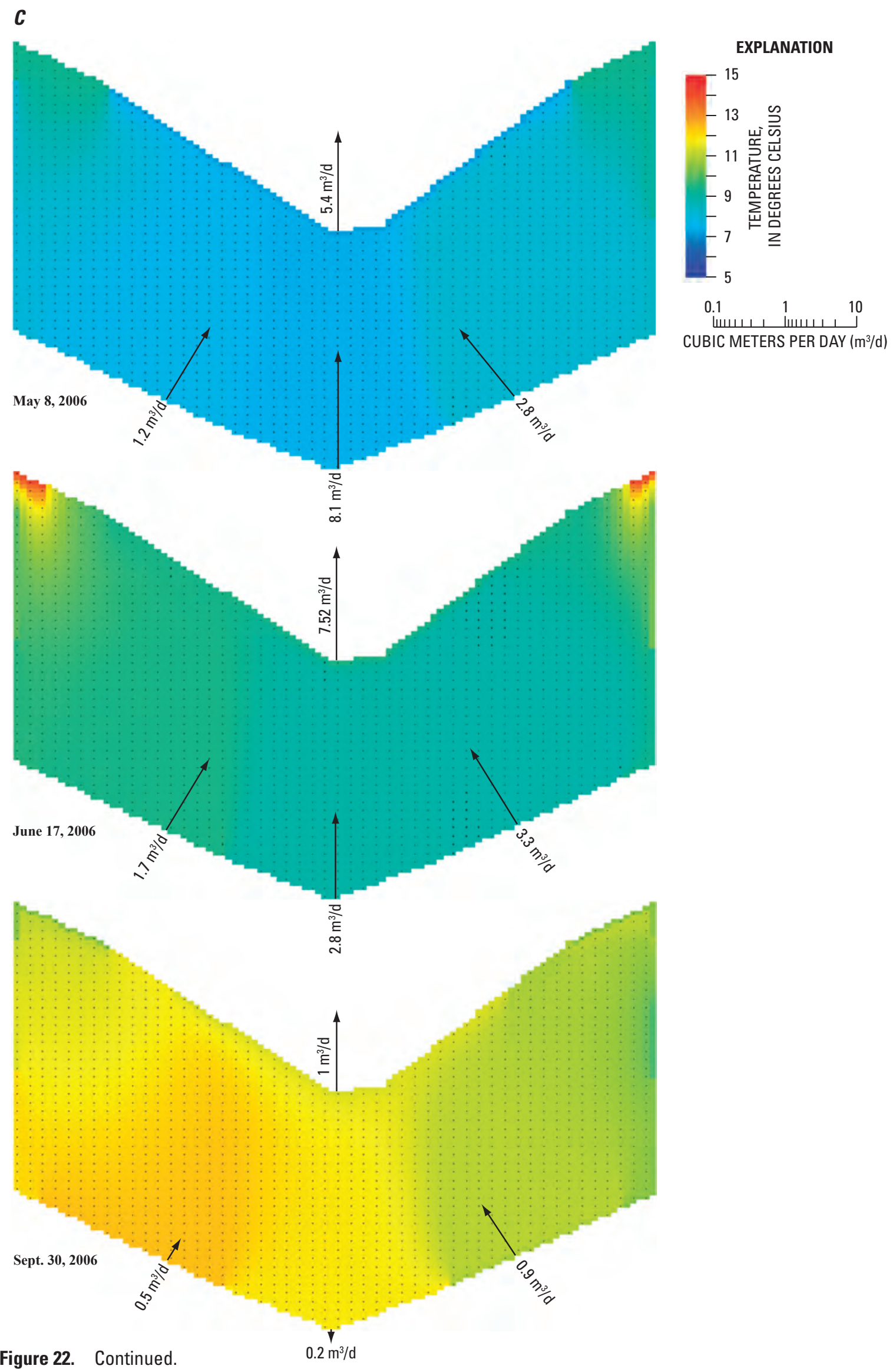




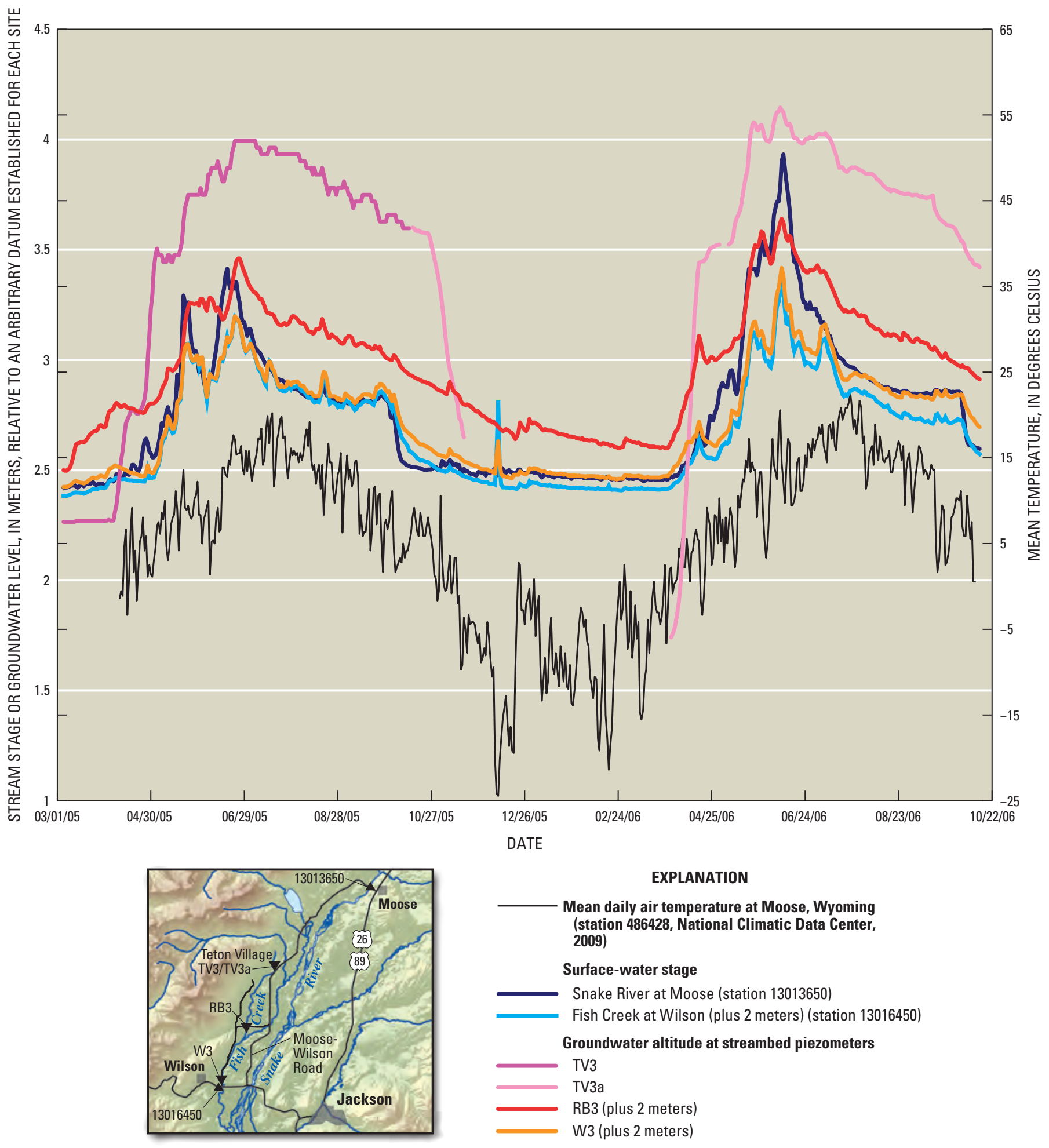

Figure 23. Average air temperature at Moose, Wyo., stage of Snake River and Fish Creek, and groundwater levels at selected piezometers in the study area. (All stage and groundwater altitudes are relative to an arbitrary datum established for each site.) 
system package (Teton County, 2009). The estimated volume of water discharged from groundwater into the stream was $3,700 \mathrm{~m}^{3} / \mathrm{d}$ on the basis of the flux calculation. The estimated volume of groundwater discharged into Fish Creek during August 2004, based on the seepage investigation, was $58,000 \mathrm{~m}^{3} / \mathrm{d}$ (Wheeler and Eddy-Miller, 2005). These two estimates differ by a factor of about 16 , likely as a result of spatial differences along the reach of the Teton Village seepage investigation compared to the cross section and temporal differences in the hydrologic system (e.g. snow melt infiltration, amount of irrigation application, or stage of the Snake River) during the 2 years.

The Teton Village cross section where flux was simulated is at the downstream end of the seepage investigation reach. Due to the potential variance of flux along the $1.5-\mathrm{km}$ reach, as demonstrated by the difference in flux among the three cross sections, it is likely that fluxes determined at the lower end of the reach were less than the average flux for the entire reach in 2006.

Evaluation of streamflow and stage at nearby gaging stations also indicates that Fish Creek had more flow in August 2004 than in August 2006. The Fish Creek at Wilson gaging station recorded 1.4 times more flow in August 2004 than in August 2006 (U.S. Geological Survey, 2008). The river stage at the Snake River at Moose gaging station (13013650) was much higher in 2004 than in 2006 - the lowest stage recorded in August 2004 (2.93 m, August 15-18) was equal to the highest stage recorded in August 2006. Because the Snake River is a source of water for Fish Creek, it is likely that the higher stages in the Snake River and infiltration of irrigation diversions resulted in increased groundwater recharge and thus increased flux from groundwater to Fish Creek.

Although there were inherent errors with estimations of hydraulic parameters, fluxes, and average flux over the reach, it was useful to compare the two methods to determine if similar values for flux would be obtained. Although the two methods produced different flux estimates for the two different years (2004 and 2006), supporting information indicates that the flux in 2004 would have been larger than the flux in 2006, and the calculations support the use of both methods for flux estimation.

\section{Resor's Bridge Cross Section}

Water fluxes at the Resor's Bridge cross section were estimated across four model boundaries: streambed, eastern side (left bank), bottom of model, and western side (right bank; fig. 24). The estimated daily flux (averaged for each month) of water from the groundwater into Fish Creek ranged from -3.8 to $7.4 \mathrm{~m}^{3} / \mathrm{d}$ (table 3 ) at the Resor's Bridge cross section. The estimated fluxes show that most of the flux from groundwater to the surface water occurred from mid-April to mid-August as indicated by the highest positive fluxes in figure $24 \mathrm{~A}$. The cumulative monthly flux to Fish Creek from groundwater was highest during June $2006\left(222 \mathrm{~m}^{3}\right)$. Most of this flux likely resulted from a rise in groundwater level caused by infiltration of valley snowmelt, a snowmelt pulse from the mountain range to the west, an increased flux from the Snake River into the alluvial aquifer, and infiltration of applied irrigation water. The flux switched to near equilibrium during late August to early September when the groundwater levels began to slowly decline, likely as a result of reduced recharge from mountain snowmelt and the Snake River. Fish Creek at the Resor's Bridge cross section became a losing reach during the fall and winter as groundwater levels continued to decline when recharge from sources such as mountain snowmelt, the Snake River, and irrigation water tapered off. The largest cumulative monthly flux of water from Fish Creek to groundwater occurred during November $2005\left(114 \mathrm{~m}^{3}\right)$.

Fish Creek had both gaining and losing periods at the Resor's Bridge cross section, whereas it was always gaining at Teton Village. The timing of increases and decreases in the water table at the Resor's Bridge and Teton Village cross sections was similar, although the duration of the higher fluxes of water from groundwater to the creek did not last as long at the Resor's Bridge cross section. The differences in response and timing of changes in the stream for Resor's Bridge were likely due to the location of the cross section, which is downstream from the Teton Village cross section. The increased distance could cause a delay in and dampening of responses to irrigation and other recharge. Additionally, as noted by Nelson Engineering (1992), water-table fluctuations generally decrease in the downstream direction.

Figure $24 A$ shows that although there are only 16 months of data, the seasonal pattern appears to repeat. In general, the flux across the streambed boundary had a similar pattern, with a slight lag, to that of the stream stage and that of the water level in the piezometer. The flux was from groundwater to the stream during spring to midsummer. Comparisons of flux across the streambed boundary to precipitation showed little correlation, indicating that groundwater inflow is a more prominent component of streamflow input than surface runoff.

During high flow in 2006, in particular, some of the flux that discharged through the streambed was across the right (western) side boundary. The flux across the western side also can be seen in the thermographs from the Resor's Bridge cross section and a nearby perennial spring (fig. 28 in the "Supplemental Information" section). In contrast to the temperatures at piezometers RB1 and RB2 on the eastern side, temperatures at piezometers RB4 and RB5 on the western side are similar in magnitude to temperatures at Resor's Spring (upstream; fig. 2, fig. 28), indicating that the source of shallow groundwater on the right bank is potentially similar to the water source of the spring.

\section{Wilson Cross Section}

Water fluxes at the Wilson cross section were estimated across four model boundaries: streambed, eastern (left) side, bottom of model, and western (right) side (fig. 25). Although the model boundaries do not represent the entire area where water could possibly flow into or out of the model domain 

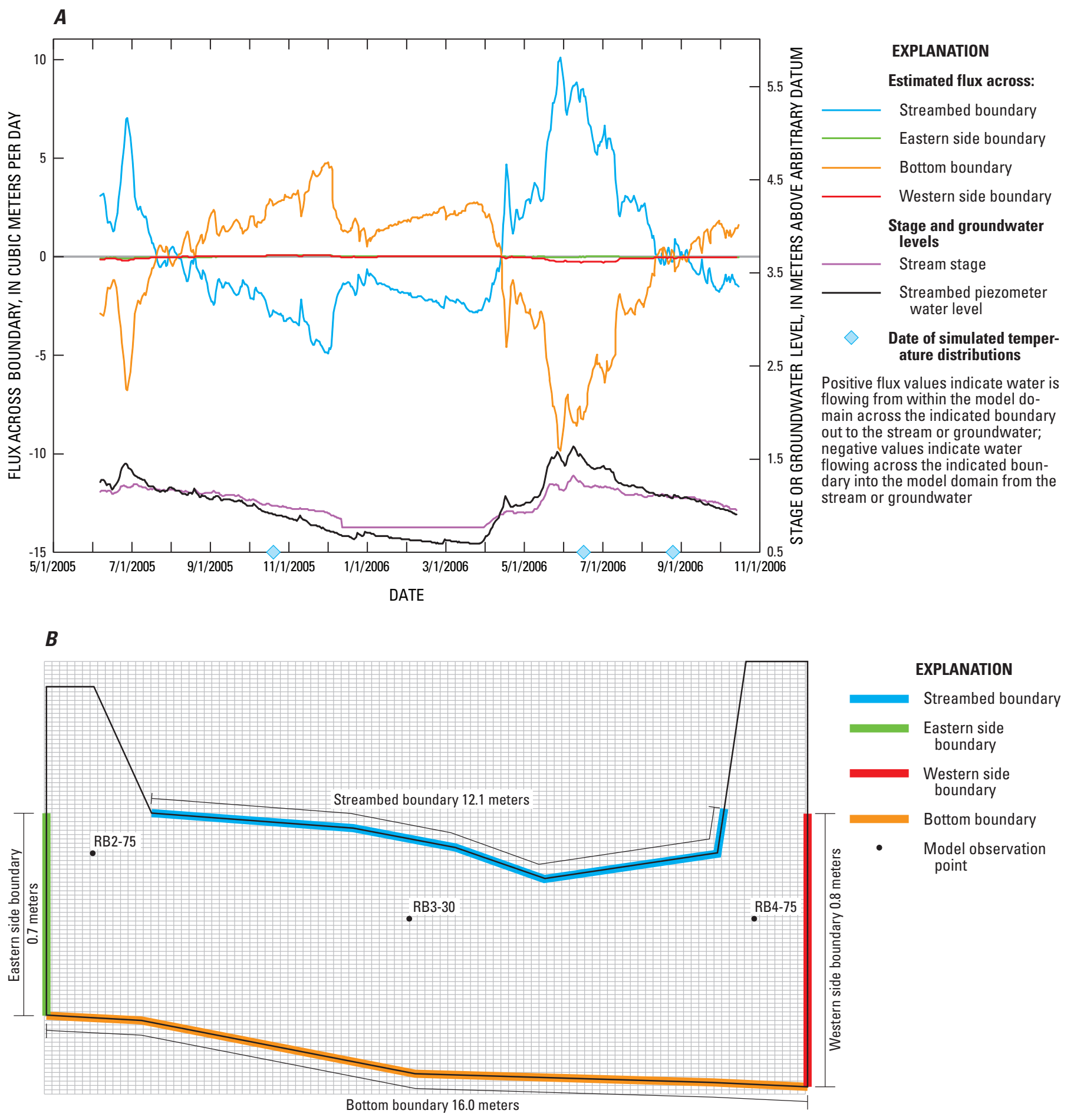

Figure 24. Selected flux information for the Resor's Bridge cross section. $A$, Daily flux across streambed, eastern side, bottom, and western side boundaries; stage of Fish Creek; and water level in the streambed piezometer (RB3) from June 6, 2005, to 0ctober 14, 2006. $B$, Location and length of flux boundaries in model for which output is shown in $A$. $C$, Simulated temperature distributions inside the model domain on three selected dates (arrows indicate direction and relative magnitude of water flux). 

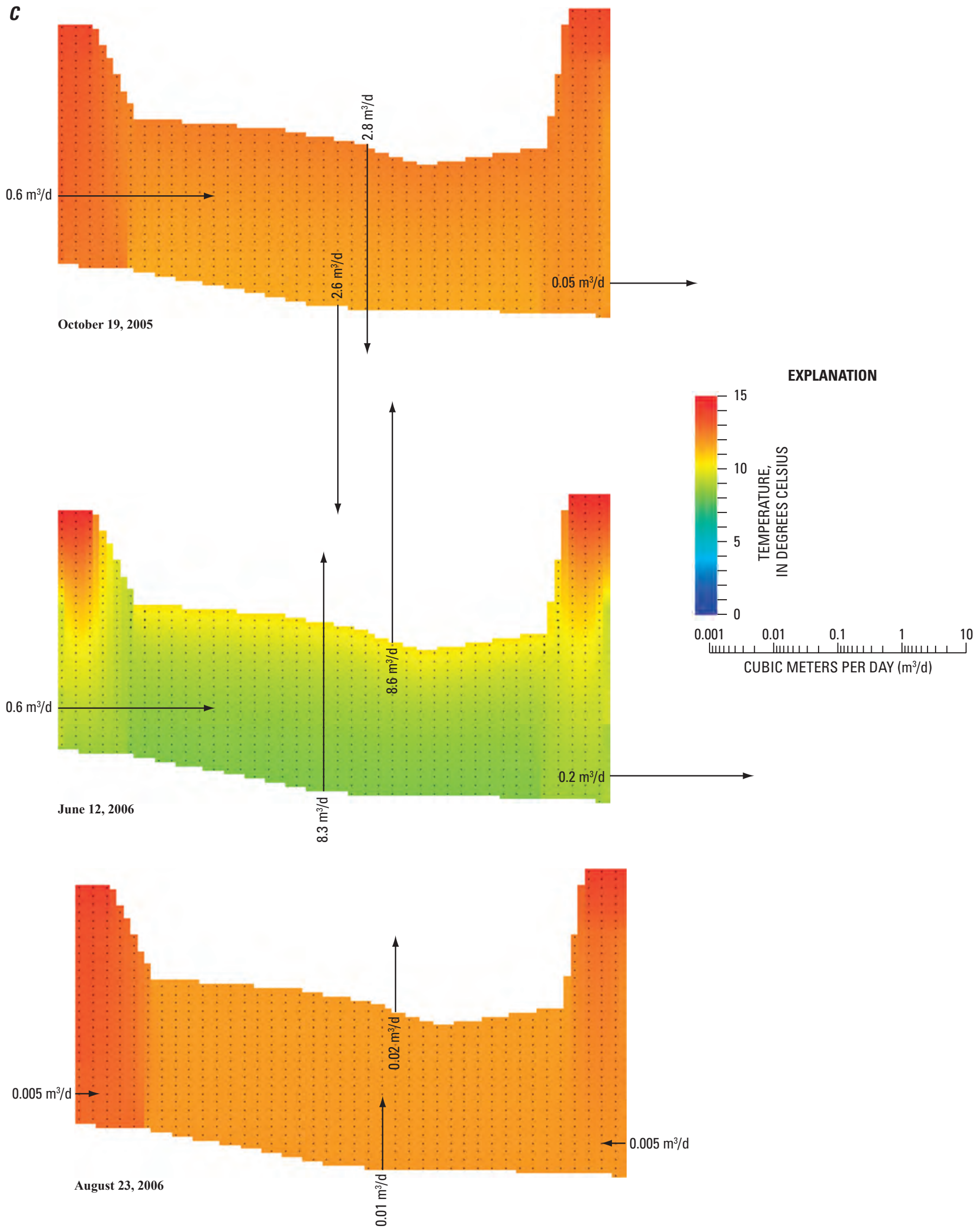

Figure 24. Continued. 

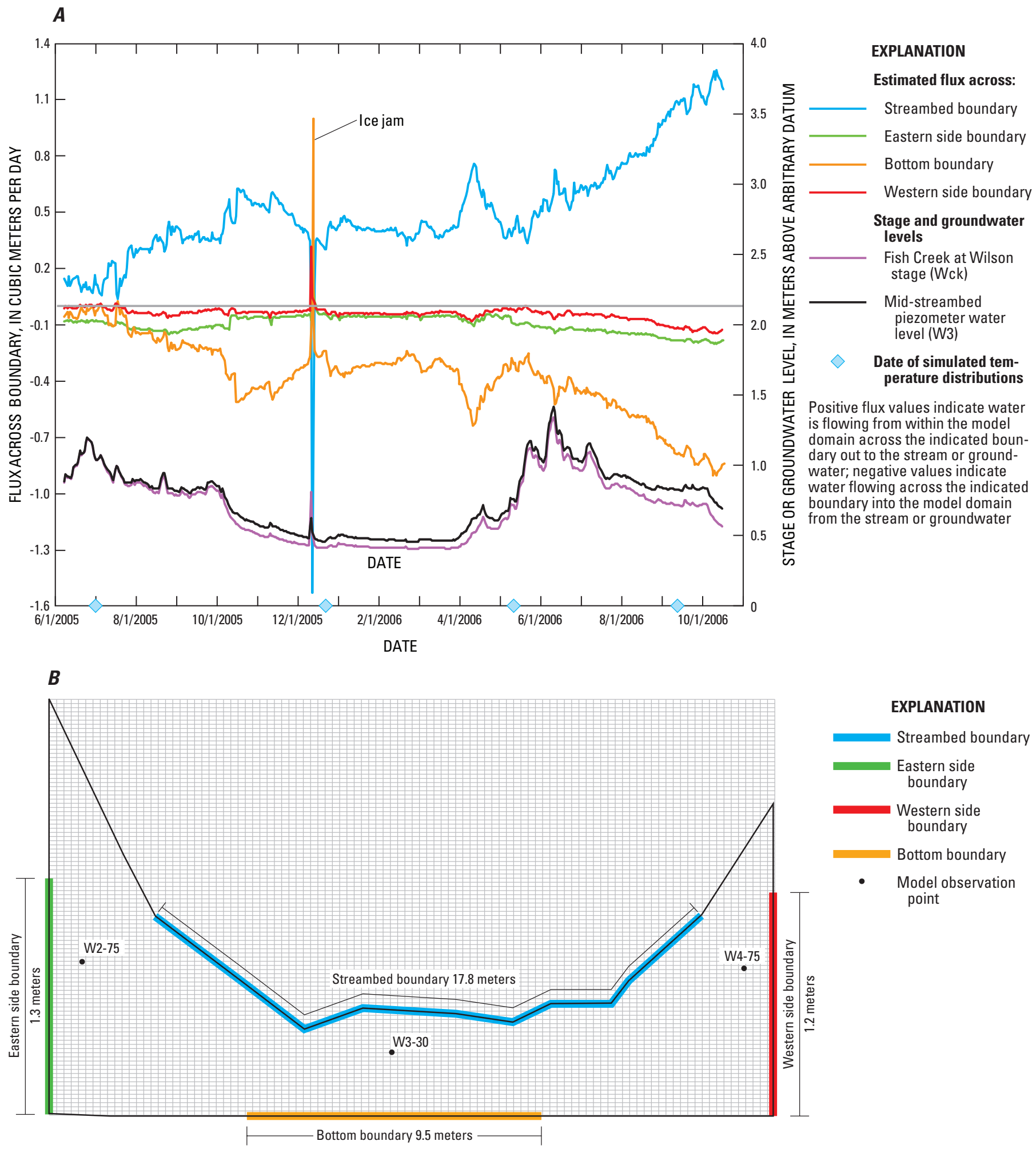

Figure 25. Selected flux information for the Wilson cross section. $A$, Daily flux across streambed, eastern side, bottom, and western side boundaries; stage of Fish Creek; and water level in the streambed piezometer (W3) from June 6, 2005, to 0ctober 14, 2006.

$B$, Location and length of flux boundaries in model for which output is shown in $A$. $C$, Simulated temperature distributions inside the model domain on four selected dates (arrows indicate direction and relative magnitude of water flux). 


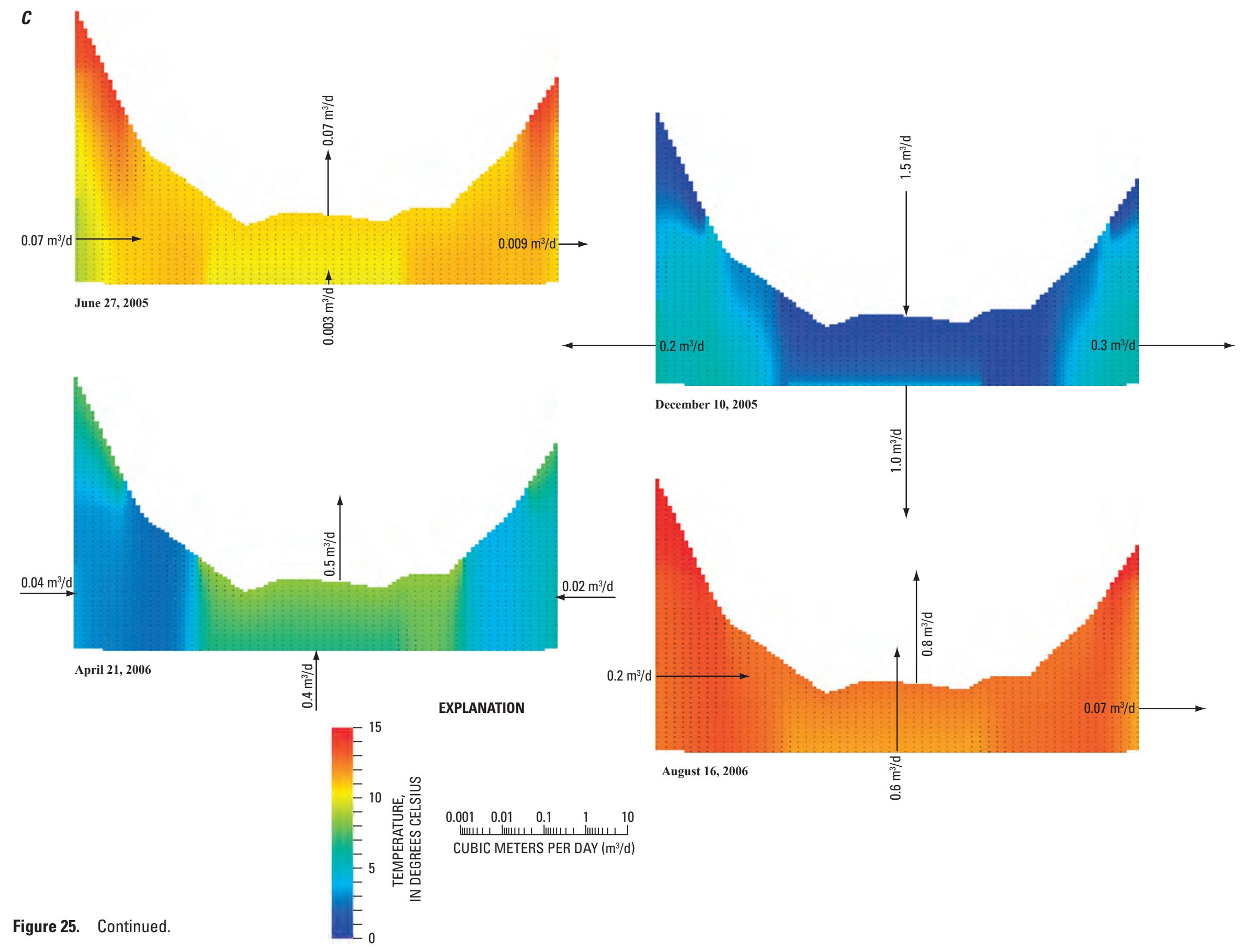

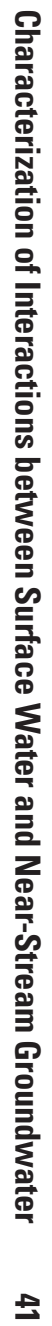


(because of the lack of a continuous bottom boundary), the flux estimate provides valuable information about the sources of water flux into the stream, the amount of flux from groundwater to the stream, and the relation between flux and groundwater levels and stream stage at the cross section.

The flux distribution shows that the contribution of water into the model domain across the eastern and western sides is small compared to the contribution across the bottom boundary (fig. 25A), which is similar in length (fig. 25B). Most of the water exiting the model through the streambed came into the model across the bottom boundary. Figure $25 \mathrm{~A}$ also shows that more flux enters the model domain from the eastern side of the stream than from the western side. The estimated daily flux of water (averaged for each month) into Fish Creek at the Wilson cross section ranged from 0.1 to $1.2 \mathrm{~m}^{3} / \mathrm{d}$ (table 3 ), and was about an order of magnitude smaller than the flux into the creek during gaining periods at both the Teton Village and Resor's Bridge cross sections. This indicates that although the stream is gaining, the input is small, and most of the water flowing past the cross section is from upstream. Fluxes from groundwater into the creek at the Wilson cross section ranged from 3 to $33 \mathrm{~m}^{3} /$ month during the study period.

Figure $25 \mathrm{~A}$ shows the flux of water across the model boundaries, the stage of Fish Creek, and the groundwater level in the streambed piezometer (W3). The flux of water between the stream and the nearby groundwater was nearly always from the groundwater to the stream. The only exception was during an ice jam that raised the stage of the stream during December 2005. Cold temperatures produced an ice dam in the stream near the Fish Creek at Wilson gaging station, producing a short period of backwater stages and groundwater flux reversal (figs. 7 and 25A). A visual comparison of flux, stream stage, and groundwater levels showed that unlike the fluxes at the Teton Village and Resor's Bridge cross sections, the flux into Fish Creek at Wilson was relatively steady and did not vary with the changes in stage and groundwater levels that occurred throughout the year.

The pattern of water flux from groundwater into the stream (fig. 25A) shows little correlation to temperature recorded at Moose (fig. 23). This was likely due to the location of the Wilson cross section in the watershed (downstream from the other two cross sections) and the input of tributary surface water that would account for more water in the stream during the high flow time of the year. The higher streamflow would likely result in a smaller proportion of groundwater inflow relative to that at the Teton Village and Resor Bridge cross sections.

\section{Comparison between Simulated Fluxes and Streamflow Gains/Losses from 2004 Seepage Investigation}

Comparison between the flux estimates from model simulations and the streamflow gains and losses determined during the 2004 seepage investigation (Wheeler and Eddy-Miller,
2005 ) is helpful for determining patterns in the hydrologic system. Although the same flux values are not expected in two different years, the patterns in flux summaries were similar to those resulting from the seepage measurements in August and November 2004 (fig. 3).

Stage and water-level data (fig. 19) and simulated fluxes (fig. 22) indicate that as long as there was water in Fish Creek at the Teton Village cross section, a flux from groundwater to the stream could be calculated. These data indicated a gaining stream reach, which corroborated the seepage data collected in August 2004 that indicated that the reach containing the Teton Village cross section was a gaining reach (fig. 3 ).

The fluxes at the Resor's Bridge cross section (fig. 24) during mid-August in both 2005 and 2006 were near equilibrium, which corresponds with no gain determined from the seepage data collected in August 2004 (fig. 3). The November flux data showed a downward flux from the stream to groundwater, whereas the seepage data indicated a gain in streamflow. This discrepancy could be due to several factors, including (1) the seepage investigation included the entire reach, whereas the simulation was limited to the cross section, (2) difficulty in measuring low flows at the site could have led to measurement error, (3) the streambed model boundary may not have been defined well enough for the low-flow period, and (4) patterns of flux in 2004 may have been different from patterns in 2005 and 2006.

All positive fluxes of groundwater into the stream at the Wilson cross section were about an order of magnitude smaller than those at the Teton Village and Resor's Bridge cross sections, indicating that the amount of groundwater contributing to the overall flow of Fish Creek at the Wilson cross section is small. The seepage investigation determined that the section of stream that ended at the Wilson cross section had no gain during both August and November 2004 (fig. 3), which would correspond to a minimal input of water from groundwater at the cross section. This does not necessarily indicate that the cumulative flux of groundwater into the stream in the reaches upstream and downstream from the Wilson cross section is unsubstantial, as indicated by the lack of ice on the stream during extended periods of below-freezing temperatures in the area.

\section{Synopsis of Interactions Related to the Hydrology of Fish Creek}

Total monthly fluxes of water across the streambed summarized in table 3 showed that the flux of water into and out of Fish Creek varied along the stream spatially and seasonally. The data indicated a constant flux of water from groundwater to the stream at the Teton Village cross section, a change in flux direction seasonally at the Resor's Bridge cross section (a gaining reach in the summer and a losing reach in the winter), and a constant small volume of water moving from groundwater to the stream at the Wilson cross section. 
Stream stage and groundwater levels indicate that upper Fish Creek responds rapidly to a rise in the alluvial aquifer's water level (fig. 23), likely due to several factors, including increased aquifer recharge from high flows in the Snake River, rapid infiltration of snowmelt, or infiltration of applied irrigation water. This condition of elevated ground water levels causing higher streamflows is somewhat atypical; in many streams, high streamflows commonly result in recharge to groundwater. Flow in lower Fish Creek near Wilson appears to be affected by a combination of those factors previously mentioned and by inflow from tributaries.

During the spring and early summer, fluctuations in stream stage typically coincide with mean daily air temperatures (fig. 23), due to the relation between daily snowmelt and temperatures. The rapid response to valley snowmelt can be observed in the small peak in mid-April 2005 and 2006 data from Fish Creek and the Snake River and from the streambed piezometers at the Resor's Bridge and Wilson cross sections (piezometers RB3 and W3, respectively; fig. 23). In the upper reach, near Teton Village, groundwater levels rapidly increase and decrease, likely in response to snowmelt and applied irrigation water recharging the alluvial aquifer. Generally, the same holds true midway through the Fish Creek watershed at piezometer RB3 in the Resor's Bridge cross section, although the recession of groundwater levels is smoother than at the other two cross sections as the irrigation season ends and flows decrease in the Snake River. This more gradual recession may indicate a reduced hydraulic connection. The Resor's Bridge cross section is upstream from the Lake Creek confluence, whereas the Wilson cross section is downstream. At the Wilson cross section, the water levels in piezometer W3 and stream stage at station 13016450 more closely match stage fluctuations in the Snake River than do water levels in piezometers at the two other cross sections (fig. 23). This difference is because Fish Creek at Wilson is influenced by a combination of alluvial recharge and tributary inflow from Lake Creek. (Lake Creek is directly affected by diversions from the Snake River and recharge from infiltration upgradient from Lake Creek causing an increased water table and subsequent discharge into Lake Creek.)

Specifically, the Teton Village reach is strongly influenced by two factors: (1) snow in the basin directly upstream in the watershed and (2) large fluctuations in the water table. The Resor's Bridge reach is influenced by a combination of (1) a rise in groundwater level likely due to both infiltration of valley snowmelt and recharge to the alluvial aquifer along the west bank from the higher stage of the Snake River, (2) a snowmelt pulse from the mountain range to the west, and (3) the application of irrigation water. The summer flows at Wilson are influenced by flow upstream in Fish Creek, tributary inflows, and a small, constant inflow of groundwater. Streamflows at Wilson in the winter are influenced similarly, except that tributary inflows are minimal.

The qualitative patterns of gain and loss are in general agreement with qualitative results from previous investigations. However, this study provides quantitative information that can be used for future studies of Fish Creek, such as nutrient budgets, simulation of surface water and groundwater flow, and simulations of surface water/groundwater interactions in the southwestern area of Jackson Hole.

\section{Summary}

Fish Creek, a tributary of the Snake River, is about 25 river kilometers long, and is located in Teton County in western Wyoming near the town of Wilson. Local residents began observing an increase in the growth of algae and aquatic plants in the stream during the last decade. Due to the known importance of groundwater to surface water in the area, the U.S. Geological Survey (USGS) in cooperation with the Teton Conservation District conducted a study to characterize the interactions between surface water and near-stream groundwater along Fish Creek.

The study has two main objectives: (1) develop an improved spatial and temporal understanding of water flow (fluxes) between surface water and groundwater and (2) use simulations from a two-dimensional groundwater-flow and heat-transport model to interpret measured temperature and hydraulic-head distributions and to describe groundwater flow near Fish Creek. The study is intended to augment hydrologic information derived from previously published results of a seepage investigation of Fish Creek. Seepage measurements provide spatially averaged gains and losses over an entire reach for one point in time, whereas continuous temperature and water-level measurements provide continuous estimates of gain and loss at a specific location.

Stage, water level, and temperature data were collected from surface water and from piezometers completed in an alluvial aquifer at three cross sections on Fish Creek at Teton Village, Resor's Bridge, and Wilson from October 2004 to October 2006. All three cross sections had two piezometers on the left bank (representing the eastern side of the stream), one in the center of the stream, and two on the right bank (representing the western side) of the stream. The data were used to (1) calibrate cross-sectional models of flow into or out of the stream by using the two-dimensional model VS2DH and (2) qualitatively describe the direction and relative magnitude of flow between surface water and groundwater.

The flow and energy (heat) transport model VS2DH and the graphical user interface VS2DI were used to simulate flow through the streambed of Fish Creek. Two-dimensional vertical cross sections perpendicular to the direction of streamflow were developed for each monitored cross section. The physical and hydrologic setting was characterized by using land surveys and data collected from thermistors and the stream, and from hand-measured water levels in the piezometers at each cross section. The model was designed to have daily recharge periods, and simulation periods were April 15 to October 14, 2006, (183 recharge periods) for the Teton Village cross section, and June 6, 2005, to October 14, 2006, 
(496 recharge periods) for the Resor's Bridge and Wilson cross sections.

A trial-and-error technique was used to determine the best match between simulated and measured data. These results were then used to calibrate the cross-sectional models and determine horizontal and vertical hydraulic conductivities. The fluxes of groundwater into the stream or fluxes of stream water into the alluvial aquifer were estimated by using the calibrated VS2DH model.

Results of the simulations indicated that surface water/ groundwater interaction and hydraulic properties were different at the three cross-sections. At the most upstream cross section, Teton Village, Fish Creek flowed intermittently and continually gained relatively large quantities of water from April through September. During other times of the year, the stream was dry near the cross section. Saturated hydraulic conductivity set at $1 \times 10^{-4} \mathrm{~m} / \mathrm{s}$ in both the horizontal and vertical directions resulted in the best match between simulated and measured temperatures. The Resor's Bridge cross section, about midway between the other two cross sections, was near the point where perennial flow begins. At this cross section, the stream gained water from groundwater during high flow in late spring and summer, was near equilibrium with groundwater during August and September, and lost water to groundwater during the remainder of the year. Horizontal hydraulic conductivity set at $5 \times 10^{-5} \mathrm{~m} / \mathrm{s}$ and vertical hydraulic conductivity set at $1 \times 10^{-5} \mathrm{~m} / \mathrm{s}$ resulted in the best match between simulated and measured temperatures. The Wilson cross section, the most downstream site, was at USGS streamflow-gaging station 13016450. This part of the stream is perennial and was almost always gaining a small volume of water from groundwater. Saturated hydraulic conductivity set at $1 \times 10^{-4} \mathrm{~m} / \mathrm{s}$ in the horizontal direction and at $5 \times 10^{-6} \mathrm{~m} / \mathrm{s}$ in the vertical direction resulted in the best match between simulated and measured temperatures.

Quantitative values of the flux from groundwater into the stream were estimated by using VS2DH and ranged from 1.1 to $6.6 \mathrm{~m}^{3} / \mathrm{d}$ at the Teton Village cross section, from -3.8 to $7.4 \mathrm{~m}^{3} / \mathrm{d}$ at the Resor's Bridge cross section, and from 0.1 to $1.2 \mathrm{~m}^{3} / \mathrm{d}$ at the Wilson cross section. Monthly fluxes ranged from 16 to $199 \mathrm{~m}^{3} /$ month at the Teton Village cross section, from -114 to $222 \mathrm{~m}^{3} / \mathrm{month}$ at the Resor's Bridge cross section, and from 3 to $33 \mathrm{~m}^{3} /$ month at the Wilson cross section.

Stream stage and groundwater levels indicate that upper Fish Creek responds rapidly to rises in the alluvial aquifer's water level, likely due to several factors, including: rapid infiltration of snowmelt, infiltration of applied irrigation water, injection of tertiary treated sewage, and increased aquifer recharge from high flows in the Snake River. This condition of elevated groundwater levels causing higher streamflows is somewhat atypical; in many streams, high streamflows commonly result in recharge to groundwater. Flow in lower Fish Creek near Wilson appears to be affected by a combination of the previously mentioned factors and by inflow from tributaries.

In the upper reach, near the Teton Village cross section, groundwater levels rapidly increase and decrease, likely in response to snowmelt and infiltration of applied irrigation water recharging the alluvial aquifer. Generally, the same holds true midway through the Fish Creek watershed at the Resor's Bridge cross section, although the recession of groundwater levels is smoother than at the other two cross sections as the irrigation season ends and flows decrease in the Snake River. This more gradual recession may indicate a reduced hydraulic connection at the Resor's Bridge cross section. The Resor's Bridge cross section is upstream from the Lake Creek confluence, whereas the Wilson cross section is downstream. At the Wilson cross section, the water levels in piezometer W3 and stream stage at station 13016450 more closely match stage fluctuations in the Snake River than do water levels in piezometers at the two other cross sections. This difference is because Fish Creek at Wilson is influenced by a combination of alluvial recharge and tributary inflow from Lake Creek. (Lake Creek is directly affected by diversions from the Snake River and recharge from infiltration upgradient from Lake Creek causing an increased water table and subsequent discharge into Lake Creek.)

Specifically, the Teton Village reach is strongly influenced by two factors: (1) snowmelt in the basin directly upstream and (2) large fluctuations in the water table. The Resor's Bridge reach is influenced by a combination of (1) a rise in groundwater level likely due to both infiltration of valley snowmelt and recharge to the alluvial aquifer along the west bank from the higher stage of the Snake River, (2) a snowmelt pulse from the mountain range to the west, and (3) recharge from irrigation water infiltration. Summer streamflows in the Wilson reach are maintained by streamflow in the upper part of the creek, tributary inflows, and a small, constant inflow of groundwater. Winter streamflows in the Wilson reach have similar inputs, except that tributary inflows are minimal.

The qualitative patterns of gain and loss are in general agreement with qualitative results from previous investigations. However, this study provides quantitative information that can be used for future studies of Fish Creek, such as nutrient budgets, simulation of surface-water and groundwater flow, and simulation of surface water/groundwater interactions in the southwestern area of Jackson Hole. 


\section{References Cited}

Case, J.C., Arneson, C.S., and Hallberg, L.L., 1998, Preliminary 1:500,000-scale digital surficial geology map of Wyoming: Wyoming State Geological Survey Digital Product HSDM 98-1.

Constantz, J., 2008, Heat as a tracer to determine streambed water exchanges: Water Resources Research, v. 44, W00D10, doi:10.1029/2008WR006996.

Constantz, J., Jasperse, J., Seymour, D., and Su, G.W., 2003, Heat tracing the streambed along the Russian River of northern California, in Stonestrom, D.A., and Constantz, J., eds., Heat as a tool for studying the movement of ground water near streams: U.S. Geological Survey Circular 1260, p. 17-20.

Constantz, J., and Stonestrom, D.A., 2003, Heat as a tracer of water movement near streams, in Stonestrom, D.A., and Constantz, J., eds., Heat as a tool for studying the movement of ground water near streams: U.S. Geological Survey Circular 1260, p. 1-6.

Cox, E.R., 1974, Water resources of Grand Teton National Park, Wyoming: U.S. Geological Survey Open-File Report 74-1019, $114 \mathrm{p}$.

Cox, M.H., Su, G.W., and Constantz, J., 2007, Heat, chloride, and specific conductance as ground water tracers near streams: Ground Water, v. 45, no. 2, p. 187-195.

Essaid, H.I., Zamora, C.M., McCarthy, K.A., Vogel, J.R., and Wilson, J.T., 2008, Using heat to characterize streambed water flux variability in four stream reaches: Journal of Environment Quality, v. 37, p. 1010-1023.

Freeze, R.A., and Cherry, J.A., 1979, Groundwater: Englewood, N.J., Prentice Hall, Inc., 604 p.

Healy, R.W., 2008, Simulating water, solute, and heat transport in the subsurface with the VS2DI Software Package: Vadose Zone Journal, v. 7, no. 2, p. 632-639.

Healy, R.W., and Ronan, A.D., 1996, Documentation of computer program VS2DH from simulation of energy transport variably saturated porous media - modification of the U.S. Geological Survey's computer program VS2DT: U.S. Geological Survey Water-Resources Investigations Report 96-4230, 36 p.

Hinckley Consulting and Jorgensen Engineering, 1994, Groundwater impacts of residential ponds west of the Snake River: Teton County, Wyo., Hinckley Consulting and Jorgensen Engineering Report, 54 p.
Hsieh, P.A., Wingle, W.L., Healy, R.W., 2000, VS2DI-a graphical software package for simulating fluid flow and solute or energy transport in variably saturated porous media: U.S. Geological Survey Water-Resources Investigations Report 99-4130, $16 \mathrm{p}$.

Love, J.D., and Christiansen, A.C., 1985, Geologic map of Wyoming: U.S. Geological Survey Geological map, scale 1:500,000, 3 sheets.

Love, J.D., Reed, J.C., Jr., and Christiansen, A.C., 1992, Geologic map of Grand Teton National Park, U.S. Geological Survey Miscellaneous Investigations Series Map I-2031, scale 1:62,500.

Love, J.D., Reed, J.C., Jr., and Pierce, K.L., 2003, A geological chronicle of Jackson Hole and the Teton Range: Moose, Wyo., Grand Teton Natural History Association in cooperation with U.S. National Park Service, 132 p.

National Climatic Data Center, 2009, COOP Data/Record of Climatological Observations, U.S., data for station No. 486428, Moose, Wyo., accessed May 24, 2009, at http://www.ncdc.noaa.gov/oa/mpp/.

Natural Resources Conservation Service, 2008, Wyoming monthly precipitation averages (1971-2000): Natural Resources Conservation Service, National Water and Climate Center, data for Wyoming, Phillips Bench SnoTel, accessed December 1, 2008, at http://www.wcc.nrcs.usda. gov/snow/30yrprec.html

Nelson Engineering, 1992, Teton County westbank groundwater study: Jackson, Wyo., Nelson Engineering Report, $61 \mathrm{p}$.

Niswonger, R.G., and Prudic, D.E., 2003, Modeling heat as a tracer to estimate streambed seepage and hydraulic conductivity, in Stonestrom, D.A. and Constantz, J., eds., Heat as a tool for studying the movement of ground water near streams: U.S. Geological Survey Circular 1260, p. 81-89.

Nolan, B.T., Campbell, D.L., and Senterfit, R.M., 1998, Depth of the base of the Jackson aquifer, based on geophysical exploration, southern Jackson Hole, Wyoming, USA: Springer-Verlag Hydrogeology Journal, v. 6, p. 374-382.

Nolan, B.T., and Miller, K.A., 1995, Water resources of Teton County, Wyoming exclusive of Yellowstone Nation Park: U.S. Geological Survey Water-Resources Investigations Report 95-4204, 76 p.

Oregon Climate Service, 2008, Wyoming average annual precipitation, 1961-1990: Corvallis, Oregon State University, Oregon Climate Service, digital data, accessed December 1, 2008, at http://www.ocs.orst.edu/pub/maps/Precipitation/ Total/States/WY/wy.gif 
Su, G.W., Jasperse, J., Seymour, D., Constantz, J., 2004, Estimation of hydraulic conductivity in an alluvial system using temperatures: Ground water, v. 42, no.6, p. 890-901.

Swanson, R.B., Woodruff, R.E., Laidlaw, G.A., Watson, K.R., and Clark, M.L., 2002, Water-resources data, Wyoming, water year 2001, Volume 1. Surface Water: U.S. Geological Survey Water-Data Report WY-01-1, 518 p.

Teton County, 2009, Teton County map server, accessed February 20, 2009, at http://www2.tetonwyo.org/ mapserver/.

U.S. Geological Survey, 2008, National Water Information System, accessed December 8, 2008, at $h t t p: / / w a t e r d a t a$. usgs.gov/nwis/.

Wheeler, J.D., and Eddy-Miller, C.A., 2005, Seepage investigation on selected reaches of Fish Creek, Teton County, Wyoming, 2004: U.S. Geological Survey Scientific Investigations Report 2005-5133, 15 p.

Wyoming State Engineer's Office, 2005, West bank Snake River hydrology study: Cheyenne, Wyo., Wyoming State Engineer's Office Report, 92 p.

\section{Glossary}

advection The transfer of heat by a moving fluid.

conduction The transfer of heat by direct contact.

hydraulic conductivity The rate at which water can move through a permeable medium.

piezometer A device used to measure groundwater pressure head at a point in the subsurface.

porosity The ratio of the volume of void space volume in a substrate to the total volume. 
Supplemental Information 


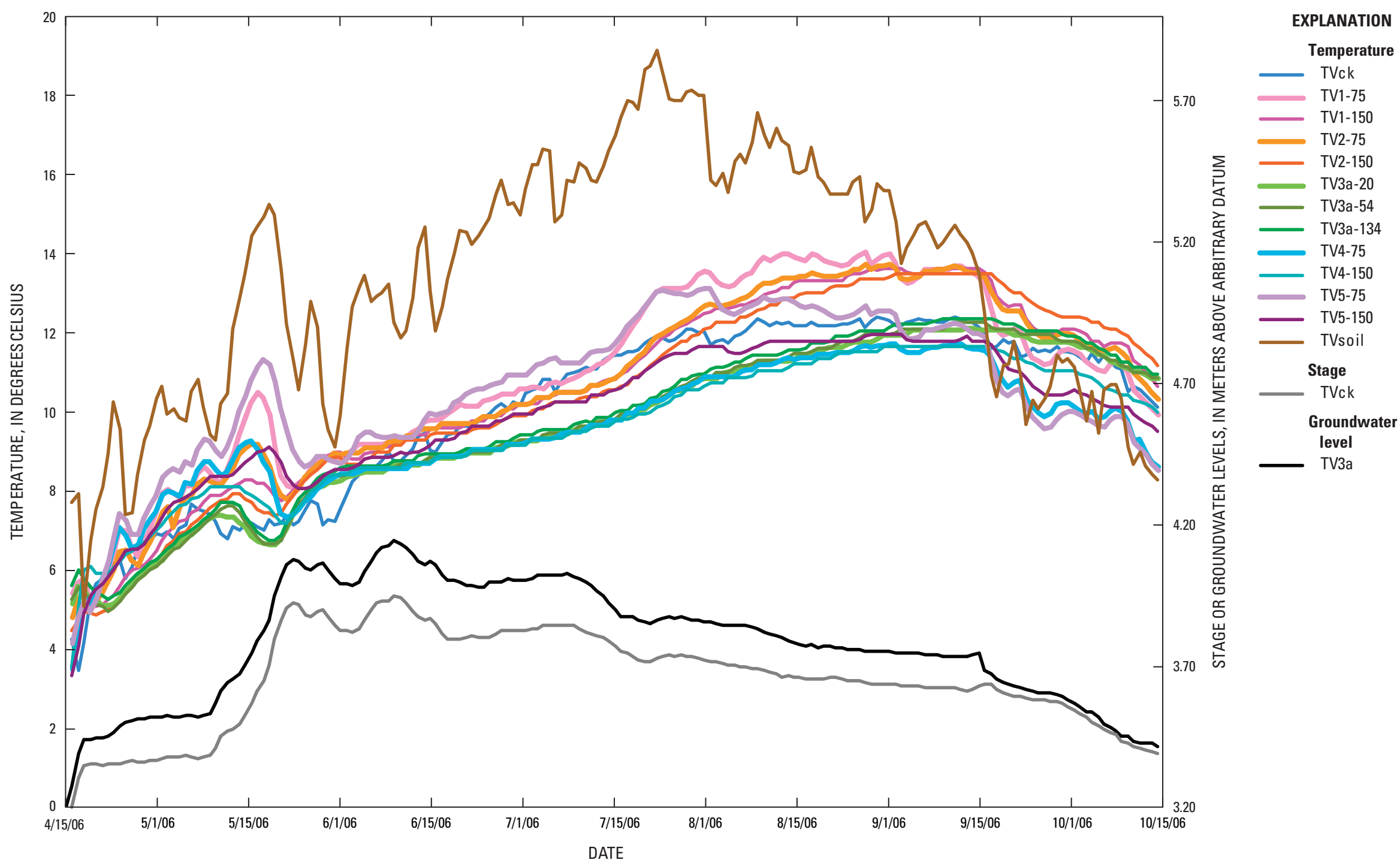

Figure 26. Data from Teton Village cross section, April to October 2006: mean daily temperatures for Fish Creek, piezometers, and soil; stage in Fish Creek; and water levels in center piezometer. 


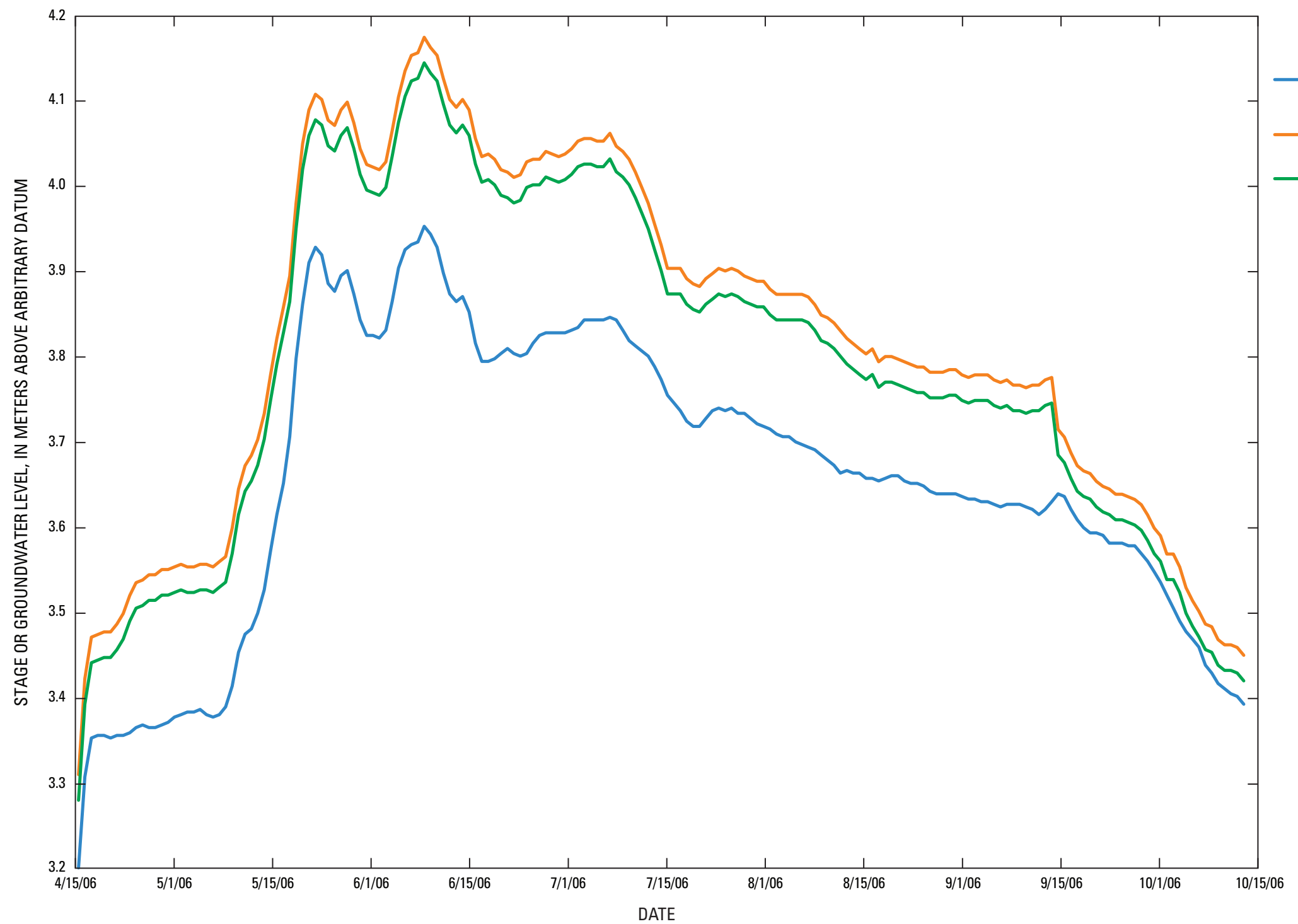

Figure 27. Stage in Fish Creek and mean daily and hand-measured water levels in piezometers, Teton Village cross section. 


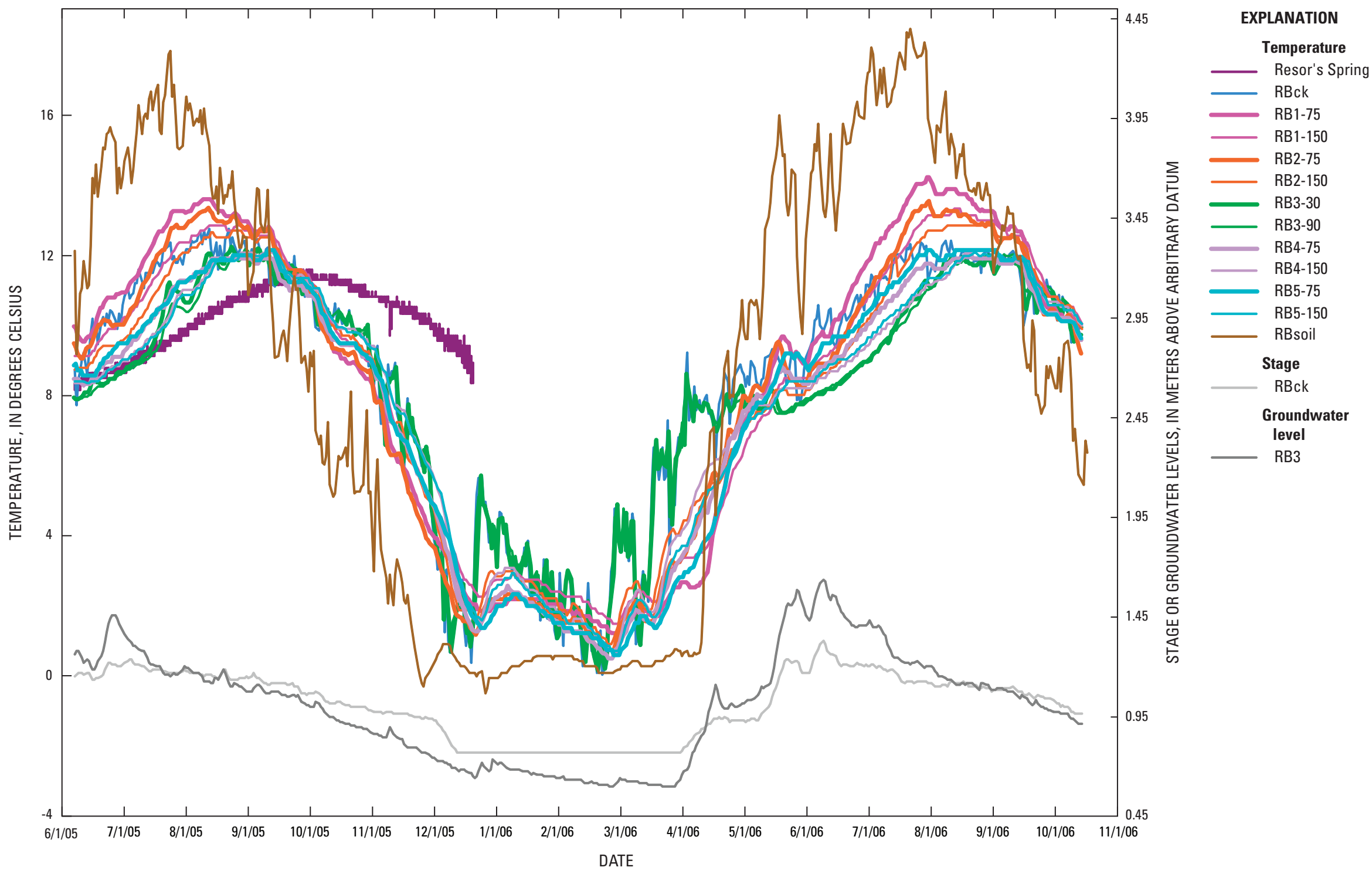

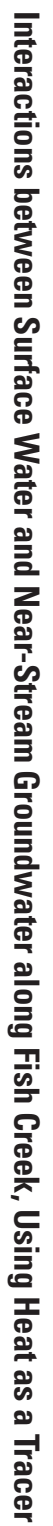

Figure 28. Data from Resor's Bridge cross section, June 2005 to October 2006: mean daily temperatures for Fish Creek, piezometers, and soil; hourly temperature in Resor's Spring; stage in Fish Creek; and water levels in center piezometer. 


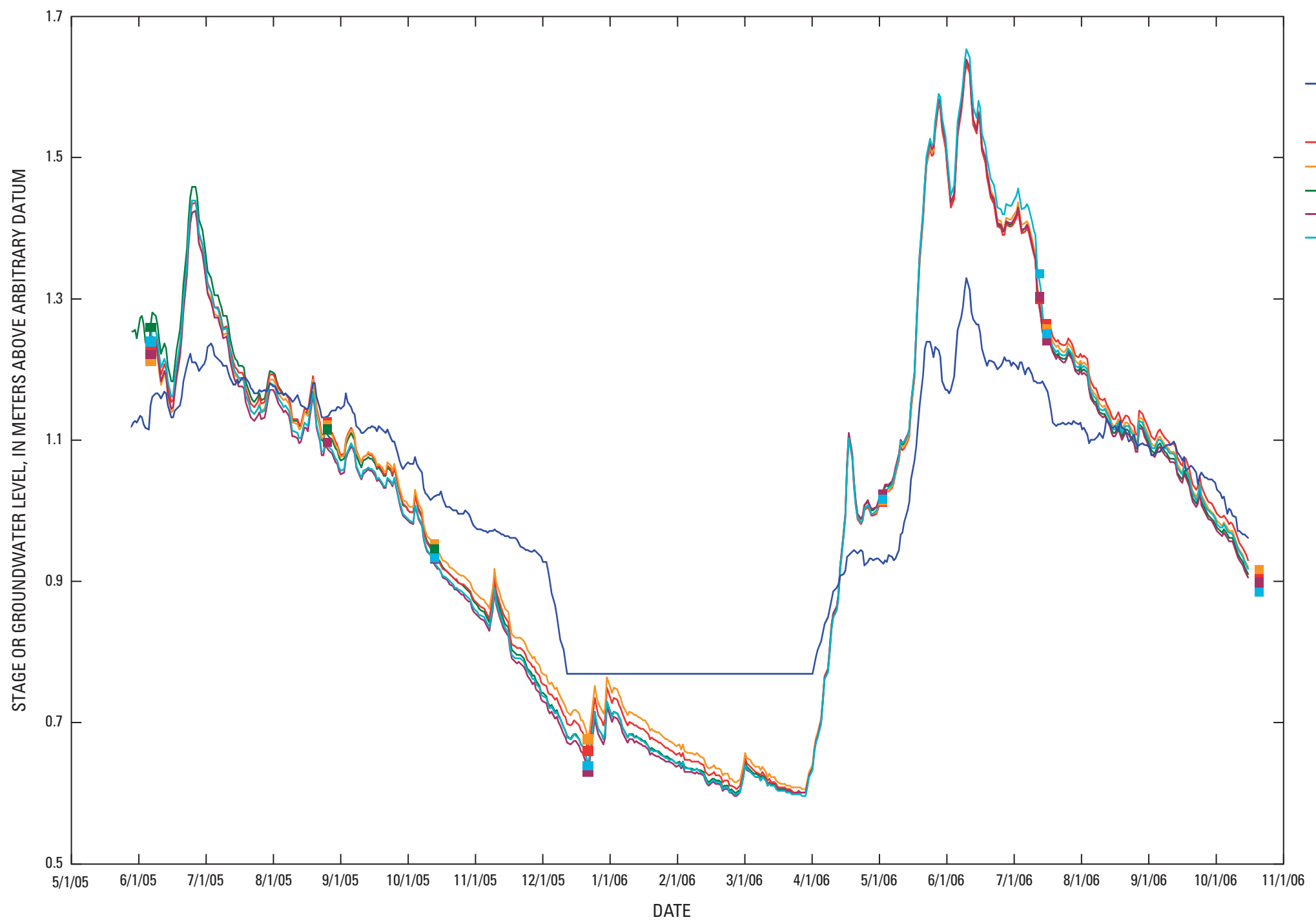

EXPLANATION

Stage

RBck

Groundwater level

RB1 interpolated

RB2 interpolated

RB3 water level

RB4 interpolated

RB5 interpolated

RB1 hand measured

RB2 hand measured

RB3 hand measured

RB4 hand measured

RB5 hand measured

Figure 29. Stage in Fish Creek and mean daily and hand-measured water levels in piezometers, Resor's Bridge cross section. 


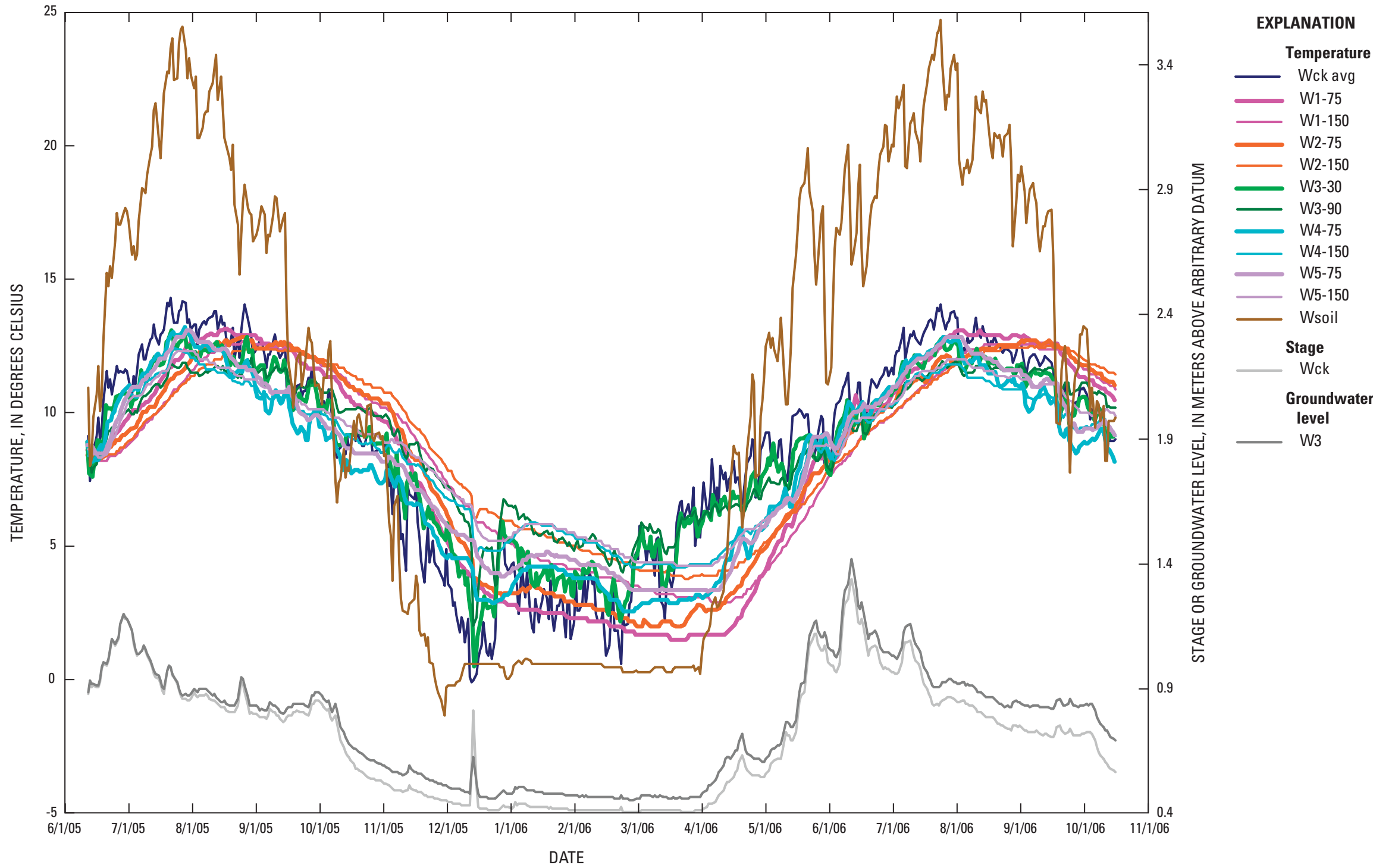

Figure 30. Data from Wilson cross section, June 2005 to October 2006: mean daily temperatures for Fish Creek, piezometers, and soil; stage in Fish Creek; and water levels in center piezometer. 


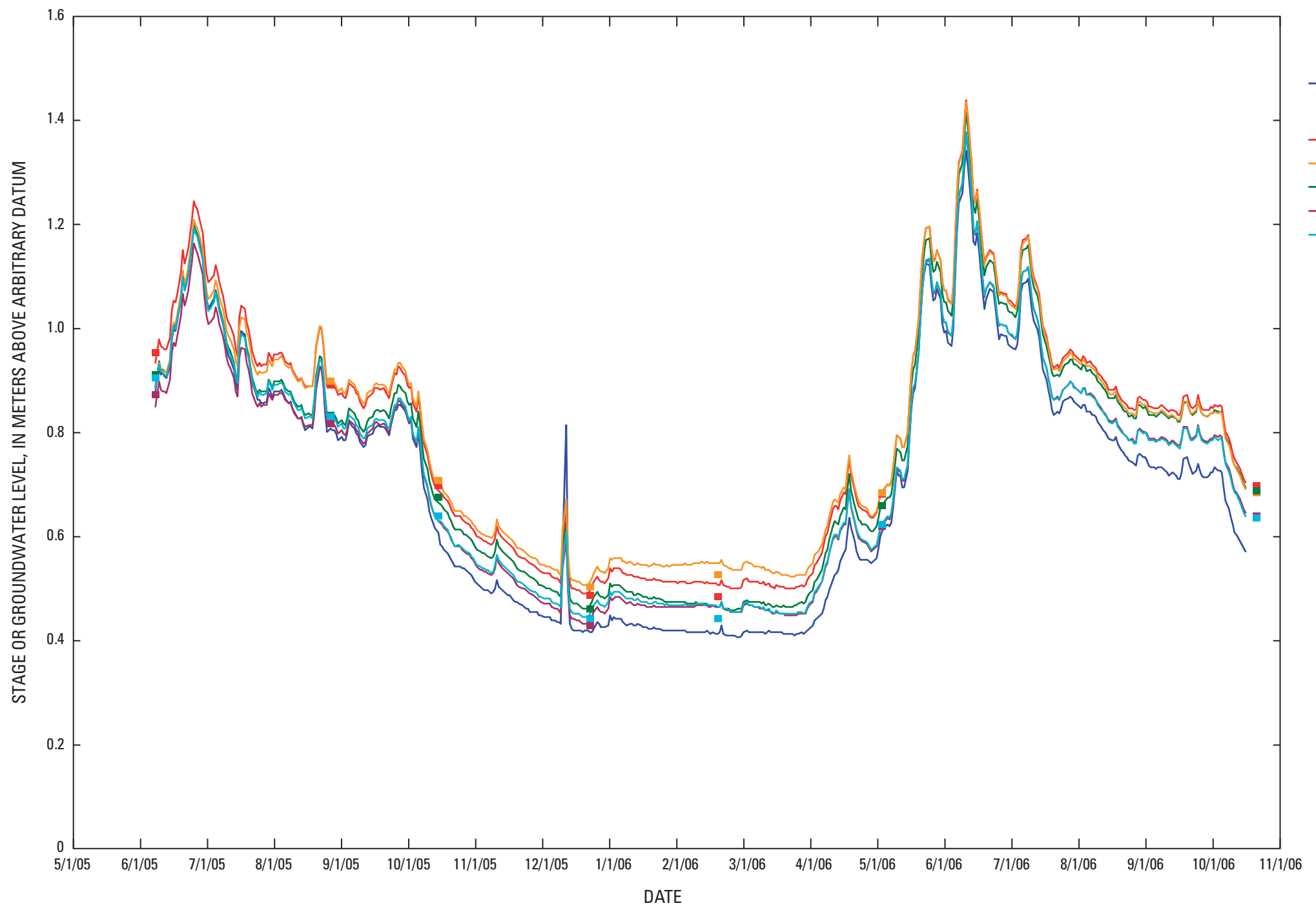

EXPLANATION

Stage

Wck

Groundwater level

W1 interpolated

W2 interpolated

W3 measured

W4 interpolated

W5 interpolated

- W1 hand measured

W2 hand measured

W/3 hand measured

- W4 hand measured

- W5 hand measured

Figure 31. Stage in Fish Creek and mean daily and hand-measured water levels in piezometers, Wilson cross section. 
Publishing support provided by:

Helena Publishing Service Center

For more information concerning this publication, contact: Director, Wyoming Water Science Center

U.S. Geological Survey

2617 East Lincolnway, Suite B

Cheyenne, Wyoming 82001

(307) 778-2931

Or visit the Wyoming Water Science Center Web site at: http://wy.water.usgs.gov 


\section{$\boldsymbol{A}$}

\section{$B$}

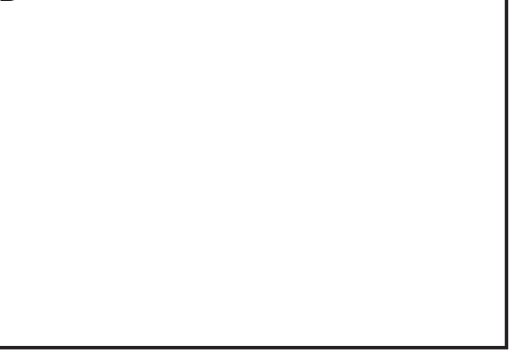

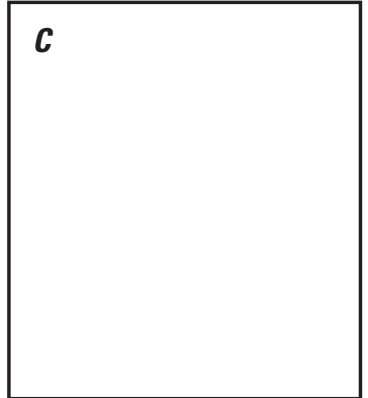

D

Back cover. Background; The Teton Range as seen from Teton Point turnout on U.S. Highway 26/89, Wyoming, May 19, 2006. Photograph by Jerrod Wheeler, U.S. Geological Survey.

A; Teton Village cross section, Wyoming, October 14, 2004. Photograph by Cheryl Eddy-Miller, U.S. Geological Survey. $\boldsymbol{B}$; Fish Creek immediately downstream from Teton Village cross section, Wyoming, August 24, 2005. Photograph by Cheryl Eddy-Miller, U.S. Geological Survey.

C; Measuring water level in TV3 piezometer, Teton Village cross section, Wyoming, October 14, 2004. Photograph by Cheryl Eddy-Miller, U.S. Geological Survey.

D; Installing thermistor in Fish Creek, Wyoming, October 13, 2005. Photograph by Jerrod Wheeler, U.S. Geological Survey. 
